\title{
De Gelderse arbeidsmarkt 2003-2008
}

Citation for published version (APA):

Borghans, L., Cörvers, F., Golsteyn, B. H. H., \& Hensen, M. M. (2005). De Gelderse arbeidsmarkt 20032008. Researchcentrum voor Onderwijs en Arbeidsmarkt, Faculteit der Economische Wetenschappen. ROA Reports No. 2 https://doi.org/10.26481/umarep.2005002

Document status and date:

Published: 01/01/2005

DOI:

10.26481/umarep.2005002

Document Version:

Publisher's PDF, also known as Version of record

\section{Please check the document version of this publication:}

- A submitted manuscript is the version of the article upon submission and before peer-review. There can be important differences between the submitted version and the official published version of record.

People interested in the research are advised to contact the author for the final version of the publication, or visit the DOI to the publisher's website.

- The final author version and the galley proof are versions of the publication after peer review.

- The final published version features the final layout of the paper including the volume, issue and page numbers.

Link to publication

\footnotetext{
General rights rights.

- You may freely distribute the URL identifying the publication in the public portal. please follow below link for the End User Agreement:

www.umlib.nl/taverne-license

Take down policy

If you believe that this document breaches copyright please contact us at:

repository@maastrichtuniversity.nl

providing details and we will investigate your claim.
}

Copyright and moral rights for the publications made accessible in the public portal are retained by the authors and/or other copyright owners and it is a condition of accessing publications that users recognise and abide by the legal requirements associated with these

- Users may download and print one copy of any publication from the public portal for the purpose of private study or research.

- You may not further distribute the material or use it for any profit-making activity or commercial gain

If the publication is distributed under the terms of Article $25 \mathrm{fa}$ of the Dutch Copyright Act, indicated by the "Taverne" license above, 


\title{
De Gelderse arbeidsmarkt 2003-2008
}

\author{
ROA-R-2005/2
}

Lex Borghans

Frank Cörvers

Bart Golsteyn

Maud Hensen

\section{Researchcentrum voor Onderwijs en Arbeidsmarkt}

Faculteit der Economische Wetenschappen en Bedrijfskunde Universiteit Maastricht

Maastricht, februari 2005 
ISBN 90-5321-402-X

Sec05.011.doc 


\section{Inhoud}

Bladzijde

Voorwoord

Ten geleide $\quad$ iii

Resumé $\quad$ vii

1 De Gelderse arbeidsmarkt in vogelvlucht 1

1.1 Inleiding 2

1.2 Kenmerken en ontwikkeling van de werkzame beroepsbevolking in Gelderland 2

1.3 De verwachte arbeidsmarktontwikkelingen in Gelderland op hoofdlijnen $\quad 5$

2 Deelname aan onderwijs en aanbod van schoolverlaters 9

2.1 Inleiding 9

2.2 Gediplomeerden in Gelderland $\quad 10$

$\begin{array}{ll}2.3 \text { Leerlingen in Gelderland } & 12\end{array}$

$\begin{array}{ll}2.4 & \text { Aanbod van schoolverlaters } \\ & 15\end{array}$

3 De vraag naar arbeidskrachten op de Gelderse arbeidsmarkt 19

$\begin{array}{ll}3.1 \text { Inleiding } & 20\end{array}$

$\begin{array}{ll}3.2 \text { Uitbreidingsvraag } & 20\end{array}$

$\begin{array}{ll}3.3 & \text { Vervangingsvraag } 26\end{array}$

3.4 Baanopeningen 31

4 Knelpunten en perspectieven op de Gelderse arbeidsmarkt 37

$\begin{array}{ll}4.1 & \text { Inleiding } \\ 4.2 & 38\end{array}$

4.2 De arbeidsmarktperspectieven voor schoolverlaters 39

4.3 Knelpunten in de personeelsvoorziening voor werkgevers 41

4.4 Uitwijk- en substitutiemogelijkheden op de arbeidsmarkt 44

5 Geografische mobiliteit van schoolverlaters en werkenden 49

5.1 Inleiding 50

5.2 Geografische mobiliteit en intrede op de arbeidsmarkt 51

5.3 Effecten van een toenemende werkgelegenheid in Gelderland op de mobiliteit

5.4 Geografische mobiliteit en knelpunten in de personeelsvoorziening in Gelderland

Bijlage A Verklarende woordenlijst $\quad 65$

$\begin{array}{ll}\text { Bijlage B Classificaties naar sector, beroep en opleiding } & 71\end{array}$

Bijlage C RAMING Digitaal 



\section{Voorwoord}

De signalen zijn duidelijk, de Gelderse economie herstelt zich. We hebben in 2004 ook belangrijke stappen voorwaarts gezet, o.a. op het gebied van innovatie, maar de aansluiting van vraag en aanbod op de arbeidsmarkt blijft een punt van aandacht. De provincie heeft hier een aanjaag- en regisseursrol, die ik denk in te vullen door bijvoorbeeld aan te dringen op convenanten tussen onderwijs en bedrijfsleven. Prestatie-afspraken hebben we nodig. De VMBO's en ROC'S moeten de leerlingen opleiden en werkgevers moeten voor stages, leer/werkplekken en banen zorgen. Het mag ons niet gebeuren dat er straks geen loodgieter of metselaar meer te vinden is terwijl er nu al jongeren werkloos langs de zijlijn staan.

RAMING II geeft een schat aan informatie over de actuele en toekomstige situatie op de Gelderse arbeidsmarkt. Het wordt ongetwijfeld een basisdocument bij de discussie over de verdeling van de Europese Structuurfondsen 2007-2013. Ongeveer twee miljard euro komt er beschikbaar voor de stad en het platteland van Nederland. Daarvan willen wij optimaal profiteren. Ik voorzie dat Raming II bij de gezamenlijke lobby die wordt ingezet een dragende rol gaat spelen.

Graag wil ik alle partijen bedanken die betrokken waren bij het tot stand komen van Raming II, lof toezwaaien voor dit prachtige eindproduct en succes toewensen bij de verdere ontwikkeling van een effectief en regionaal arbeidsmarktbeleid.

Henk Aalderink

Gedeputeerde Economische Zaken van de provincie Gelderland januari 2005 



\section{Ten geleide}

Het voorliggende rapport De Gelderse arbeidsmarkt 2003-2008 is een actualisatie van het provinciale rapport dat twee jaar geleden werd uitgebracht (De Gelderse arbeidsmarkt 2001-2006). Deze actualisatie was noodzakelijk door de drastisch gewijzigde economische vooruitzichten. De lagere economische groei en de daarmee samenhangende verslechtering van de arbeidsmarktsituatie heeft ertoe geleid dat met name jongeren veel moeilijker een passende baan kunnen vinden. In dit rapport worden de verwachte ontwikkelingen aan de vraag- en de aanbodzijde voor alle segmenten op de arbeidsmarkt toegelicht. Het rapport is op initiatief van de provincie Gelderland tot stand gekomen in het kader van het project Regionale ArbeidsMarkt INformatie Gelderland II (RAMING II als vervolg op RAMING I).

Het doel van RAMING is het ontwikkelen en actualiseren van een informatiesysteem dat een breed overzicht geeft van de toekomstige arbeidsmarktontwikkelingen in de provincie Gelderland. Uit dit overzicht komen de toekomstige discrepanties naar beroep en opleiding naar voren. Op basis van het informatiesysteem van RAMING kan door de provincie Gelderland en de verschillende arbeidsmarktparticipanten in de provincie beleid geformuleerd en uitgevoerd worden. Bovendien kan de informatie gebruikt worden voor de studie- en beroepskeuzevoorlichting. Door de toekomstige ontwikkelingen te beschrijven heeft RAMING ook een signaleringsfunctie voor verschillende andere gebruiksdoelen. Hierbij kan gedacht worden aan het personeelsen rekruteringsbeleid van werkgevers, het initiëren en bijsturen van bij- en omscholingsprogramma's voor niet-werkende werkzoekenden, de arbeidsbemiddeling en het arbeidsmarkt- en onderwijsbeleid.

De prognoses binnen RAMING zijn (deels) gebaseerd op de uitkomsten van het landelijke model waarvan de uitkomsten door het ROA zijn gepresenteerd in De arbeidsmarkt naar opleiding en beroep tot 2008 (ROA-R-2003/11). Het Bureau Economisch Onderzoek (BEO) van de provincie Gelderland heeft de prognoses voor de werkgelegenheidsgroei per bedrijfssector aan het ROA geleverd. Bij het samenstellen van deze prognoses door BEO was de consistentie met de landelijke sectorprognoses een belangrijke randvoorwaarde. Dit wordt mede bewerkstelligd doordat RAMING een regionale verbijzondering is van het door het ROA uitgevoerde landelijke Project Onderwijs-Arbeidsmarkt (POA). ${ }^{1}$

1. De methodiek van het regionale prognosemodel wordt weergegeven in F. Cörvers and $M$. Hensen (2005), 'Forecasting regional labour market developments by occupation and education', in F. van Oort, L. van Wissen and M. Thissen (eds), A survey of spatialeconomic planning models in the Netherlands. Theory, application and evaluation, te verschijnen bij het Ruimtelijk Planbureau, Den Haag. 
In het algemeen geldt derhalve dat de prognosemethodiek is afgeleid van de landelijk gebruikte methodiek binnen POA. ${ }^{2}$ Het vergelijkbare onderzoekskader van POA en RAMING maakt het mogelijk de regionale arbeidsmarktontwikkelingen relatief eenvoudig af te zetten tegen de landelijke ontwikkelingen.

Tegelijkertijd met dit rapport verschijnt ook de bijbehorende digitale statistische bijlage: RAMING Digitaal (zie ook Bijlage C). Dit is een arbeidsmarktinformatiesysteem waarmee de gebruiker zelf tabellen kan samenstellen. Het geeft een systematisch kwantitatief overzicht van de actuele arbeidsmarktgegevens en de verwachte ontwikkelingen die ten grondslag liggen aan de beschrijving op hoofdlijnen in dit hoofdrapport. De actuele arbeidsmarktinformatie en de prognoses over werkenden en schoolverlaters worden in RAMING Digitaal veel verder uitgesplitst dan in het hoofdrapport. Daarnaast bevat het RAMING Digitaal arbeidsmarktinformatie over werkzoekenden en vacatures van CWI Oost-Nederland. De arbeidsmarktgegevens met betrekking tot de werkzame en niet-werkzame bevolking zijn afkomstig uit de Enquête Beroepsbevolking (EBB) van het Centraal Bureau voor de Statistiek (CBS). Voorts is er informatie gebruikt die de Gelderse ROC's en AOC's, en de scholen in het voortgezet onderwijs van Gelderland in het kader van de Bekostigingstellingen hebben aangeleverd aan de Centrale Financiën Instellingen (Cfi/Ministerie van OCW) en de Landbouwtellingen van STOAS (i.o.v. Ministerie van LNV). Deze gegevens zijn vervolgens bewerkt door het CBS en aan het ROA ter beschikking gesteld.

Het rapport bestaat uit vijf hoofdstukken. De eerste drie hoofdstukken geven een overzicht van de toekomstige vraag- en aanbodontwikkelingen op de Gelderse arbeidsmarkt. In hoofdstuk 1 wordt een globaal overzicht gegeven van de belangrijkste arbeidsmarktontwikkelingen verbijzonderd naar bedrijfssector, beroepsklasse en opleidingscategorie. In hoofdstuk 2 wordt een overzicht gepresenteerd van de deelname aan het onderwijs in de regio en de arbeidsmarktinstroom van schoolverlaters op de Gelderse arbeidsmarkt. Hoofdstuk 3 gaat nader in op de te verwachten ontwikkelingen aan de vraagzijde van de Gelderse arbeidsmarkt op de middellange termijn, waarbij tevens een vergelijking met de verwachte vraagontwikkelingen in Nederland wordt gemaakt.

In hoofdstuk 4 worden vraag en aanbod op de arbeidsmarkt met elkaar geconfronteerd. Tevens bevat het hoofdstuk een analyse van de mogelijkheden voor schoolverlaters met een bepaalde opleidingsachtergrond uit te wijken naar verschillende beroepen op de arbeidsmarkt (uitwijkmogelijkheden), en de mogelijkheden voor werkgevers om schoolverlaters met een verschillende opleidings-

2. Zie hiervoor Bijlage $A$ in deze rapportage en 'Doel en opzet van de arbeidsmarktprognoses' in het ROA-rapport, De arbeidsmarkt naar opleiding en beroep tot 2008, ROAR-2003/11, Maastricht. Zie verder ook F. Cörvers et al. (2004), Methodiek arbeidsmarktprognoses en -indicatoren 2003-2008, ROA-W-2004/2, Maastricht; F. Cörvers, A. de Grip and H. Heijke (2002), 'Beyond manpower planning: A labour market model for the Netherlands and its forecasts to 2006', in: M. Neugart and K. Schömann (eds), Forecasting Labour Markets in OECD countries, Edward Elgar, pp. 185-223. 
achtergrond in te zetten in bepaalde beroepen (substitutiemogelijkheden). In hoofdstuk 5 staat de geografische mobiliteit van schoolverlaters en werkenden centraal. Hierbij wordt gekeken naar de mobiliteit van schoolverlaters en hun inpassing in het arbeidsproces. Daarnaast wordt een beeld geschetst van mogelijke aanpassingen naar beroepsklasse om de toekomstige discrepanties te reduceren. Tot slot wordt een indicatie gegeven van de invloed van een werkgelegenheidsverandering op de samenstelling van de Gelderse beroepsbevolking. Hierbij wordt rekening gehouden met verwachte pendel- en migratiestromen.

De projectleiding van RAMING II was in handen van F. Cörvers. Aan het hoofdrapport en het bijbehorende regionale arbeidsmarktinformatiesysteem RAMING Digitaal is meegewerkt door L. Borghans (hoofdstuk 5), S. Dijksman (RAMING Digitaal), B. Golsteyn (hoofdstuk 2), M. Hensen (hoofdstuk 3, 4 en 5) en B. Kriechel (programmatuur en prognoses).

Onze dank gaat uit naar de leden van de begeleidingscommissie van RAMING II. De voorzitter van de begeleidingscommissie was dhr. M. Walsweer van Bureau Economisch Onderzoek (BEO) van de provincie Gelderland. Hij werd bijgestaan door dhr. C. Bijkerk van de provincie Gelderland. Voorts hebben de volgende personen zitting gehad in de begeleidingscommissie: namens de Regionale Platforms Arbeidsmarktbeleid (RPA's) dhr. W. Krooshof, dhr. H. Verschoor, dhr. A.J. te Wierik, dhr. W. Spinhoven, dhr. D. Koetsier, dhr. J.Theunissen, mevr. G. Niemeijer, dhr. M. Samuels, mevr. F. Koster, mevr. M. Kousbroek en dhr. J. Peerbolte, namens de Sociale Partners Gelderland (SOPAG) mevr. H. Schats en mevr. K. van Helden, en namens CWI Oost-Nederland dhr. S.C.M. Iking. 



\section{Resumé}

\section{Vergrijzing leidt tot vraagoverschot}

- De totale verwachte werkgelegenheidsgroei van 2003 tot 2008 in Gelderland bedraagt $1 \%$ van de werkgelegenheid in 2002. De verwachte werkgelegenheidsgroei leidt tezamen met de arbeidsmarktuitstroom ten gevolge van onder meer pensionering, de uitstroom vanwege ziekte of arbeidsongeschiktheid en de tijdelijke uittrede van vrouwen, tot het totaal aan baanopeningen in Gelderland. Het aantal baanopeningen tot 2008 bedraagt naar verwachting $27 \%$ van de werkgelegenheid in 2002 . Omdat de regionale instroom van schoolverlaters op de arbeidsmarkt naar verwachting $23 \%$ zal zijn, moet er in 2008 rekening worden gehouden met een vraagoverschot op de Gelderse arbeidsmarkt.

- De uitbreidingsvraag draagt voor ongeveer een vijfde deel bij aan het totaal aantal baanopeningen binnen beroepen tot 2008 , terwijl vier vijfde deel van de baanopeningen door de vervangingsvraag tot stand komt. Met name de vergrijzing van de Gelderse beroepsbevolking zorgt voor een hogere vervangingsvraag waardoor ook het aantal baanopeningen relatief groot is ten opzichte van Nederland. Het procentuele vraagoverschot voor Gelderland is hierdoor groter dan voor Nederland. In Gelderland is 20 tot $21 \%$ van de werkzame beroepsbevolking tussen 50 en 65 jaar oud. Alleen voor de provincies Friesland, Limburg en Zeeland is de vergrijzing groter.

\section{Relatief veel werkgelegenheid in de technische en agrarische beroepen}

- De oververtegenwoordiging van de Gelderse werkgelegenheid in de Technische, ambachts- en industrieberoepen hangt samen met de relatief grote omvang van de werkgelegenheid in de bedrijfssectoren Overige industrie, Voeding, Bouw en onroerend goed en Handel en reparatie. De relatief grote werkgelegenheid in de Agrarische beroepen en de Technische, ambachts- en industrieberoepen lijkt vooral gebaseerd te zijn op het grote aantal lager en middelbaar opgeleiden met een agrarische of technische achtergrond, terwijl de oververtegenwoordiging van de werkgelegenheid in de Medische en paramedische beroepen vooral gebaseerd lijkt te zijn op het grote aandeel hoger opgeleiden met een (para)medische opleidingsachtergrond. De werkgelegenheid is laag ten opzichte van Nederland binnen de Openbare orde- en veiligheidsberoepen, de Culturele beroepen en de Informaticaberoepen. Verder blijkt dat de stijging van de Gelderse werkgelegenheid tussen 1998 en 2002 zich vooral heeft geconcentreerd bij de universitair opgeleiden. 


\section{Opscholen van werkenden zonder startkwalificatie van groot belang}

- In totaal zijn er in Gelderland ongeveer 240.000 personen aan het werk die geen startkwalificatie - minimaal MBO-niveau - voor de arbeidsmarkt hebben. Deze ongeschoolden en laag opgeleiden - ruim een kwart van de werkzame beroepsbevolking in Gelderland - zijn qua competenties minder goed toegerust om bij technologische en organisatorische veranderingen te kunnen blijven functioneren. Om te voorkomen dat deze personen als gevolg daarvan uiteindelijk zelfs de arbeidsmarkt de rug toekeren, is het noodzakelijk hen tijdig te begeleiden naar een hoger baanniveau door bijv. 'learning-by-doing' in banen met een hoge 'learning content', in combinatie met aanvullende scholing ('training-on-the-job').

\section{Afnemende belangstelling voor technisch onderwijs in Gelderland}

- De arbeidsmarktinstroom van MBO'ers tot 2008 als percentage van de werkende beroepsbevolking ligt voor Gelderland over het algemeen even hoog als voor Nederland. In overeenstemming met het landelijke beeld heeft $V M B O$ Economie een veel hoger dan gemiddelde arbeidsmarktinstroom, en MBO Natuur en techniek een lager dan gemiddelde arbeidsmarktinstroom. Opmerkelijk is verder de ten opzichte van Nederland relatief grote arbeidsmarktinstroom van schoolverlaters zonder enig diploma op de Gelderse arbeidsmarkt. Met name VMBO Economie en VMBO Verzorging zijn gedurende de laatste jaren populairder geworden, ten koste van VMBO Natuur en techniek. Ook het aandeel MBO'ers met een diploma Natuur en techniek op zak is aan het afnemen. In 2003 had Dienstverlening en Gezondheidszorg de meeste MBO-gediplomeerden, terwijl in 1998 Natuur en techniek nog de meeste gediplomeerden van het $\mathrm{MBO}$ afleverde. De lage verwachte toekomstige arbeidsmarktinstroom voor MBO Natuur en techniek is in overeenstemming met de achterblijvende belangstelling voor deze richting onder leerlingen van het MBO.

- Leerlingen in het MBO kunnen hun diploma halen via de meer praktisch georiënteerde beroepsbegeleidende leerweg (BBL, het voormalige leerlingwezen) of via de meer theoretisch georiënteerde beroepsopleidende leerweg (BOL). Het aandeel BBL-gediplomeerden is het grootst in $M B O$ Natuur en techniek (59\%) en het kleinst in MBO Economie (23\%).

\section{Tweedeling in werkgelegenheidsgroei naar opleidingsniveau}

- De vooruitzichten met betrekking tot de uitbreidingsvraag tot 2008 zijn in Gelderland ten opzichte van Nederland gunstiger voor de Pedagogische beroepen, de Openbare orde- en veiligheidsberoepen en de Culturele beroepen, en ongunstiger voor de Transportberoepen en de Sociaalculturele beroepen. Verder is er wat betreft de uitbreidingsvraag in Gelderland een tweedeling naar opleidingsniveau zichtbaar, met ongunstige verwachtingen voor de werkgelegenheid van degenen die geen start- 
kwalificatie hebben, dat willen zeggen de ongeschoolden en de lager geschoolden (tot MBO).

\section{Relatief veel baanopeningen aan de onderkant van de arbeidsmarkt}

- $\mathrm{Er}$ is in Gelderland sprake van een hoge vervangingsvraag voor de Openbare orde- en veiligheidsberoepen en de Pedagogische beroepen. Dat komt voor een belangrijke deel door het vergrijsde personeelsbestand in deze beroepsklassen. Omgekeerd valt de lage vervangingsvraag bij de Informaticaberoepen toe te schrijven aan het grote aandeel jongeren dat in deze beroepen werkzaam is. De vervangingsvraag is hoog voor Basisonderwijs, VMBO Theorie en VMBO Natuur en techniek. Met name voor werkenden die geen beroepsopleiding hebben gevolgd, geldt dat zij na verloop van tijd - mede als gevolg van het gebrek aan carrièreperspectief relatief vaak aan een postinitiële opleiding gaan deelnemen. De vervangingsvraag die daardoor ontstaat vormt voor Basisonderwijs en VMBO Theorie een belangrijk deel van de totale vervangingsvraag.

- Voor alle beroepsklassen met uitzondering van de Economisch-administratieve beroepen, de Sociaal-culturele beroepen en de Transportberoepen is het percentage baanopeningen in Gelderland groter dan voor Nederland. Verder is het opmerkelijk dat de baanopeningen in Gelderland relatief vaak aan de onderkant van de arbeidsmarkt ontstaan.

\section{Goede arbeidsmarktperspectieven in 2008 voor (V)MBO Natuur en techniek}

- Hoewel het aantal baanopeningen ten opzichte van Nederland groot is voor Basisonderwijs (voornamelijk 'drop outs' van het VMBO) en VMBO Economie, wordt tot 2008 het aantal vrijkomende banen overtroffen door de grote instroom van schoolverlaters met een dergelijke opleidingsachtergrond. Dit resulteert in ongunstige arbeidsmarktperspectieven voor deze schoolverlaters. Daarentegen is voor VMBO Theorie en VMBO Natuur en techniek het aantal baanopeningen beduidend groter dan de arbeidsmarktinstroom van schoolverlaters. Dit resulteert in goede arbeidsmarktperspectieven voor schoolverlaters met dergelijke opleidingen.

- $\quad$ Op MBO-niveau komen er zowel ten opzichte van het Gelderse gemiddelde als ten opzichte van Nederland relatief weinig banen vrij. Toch zijn de perspectieven voor MBO Natuur en techniek goed omdat er te weinig schoolverlaters in de pijplijn van het onderwijs zitten. Dit geldt in mindere mate ook voor MBO Economie en MBO Dienstverlening en gezondheidszorg. Voor sommige opleidingstypen binnen deze twee richtingen worden echter slechte perspectieven verwacht. Daaronder vallen ook populaire opleidingstypen als MBO ICT en MBO sociaal-pedagogisch en welzijn. Deze slechte perspectieven worden geheel veroorzaakt door de erg hoge instroom van schoolverlaters met dergelijke opleidingen op de arbeidsmarkt. Opvallend 
zijn verder de goede arbeidsmarktperspectieven voor een aantal medischtechnische opleidingen.

- Van belang zijn tevens de mogelijkheden voor schoolverlaters om uit te wijken naar beroepen buiten het eigen beroependomein, welke voor het VMBO en de meer algemeen vormende opleidingen zoals HAVO/VWO wat groter zijn dan voor het MBO. De geringere uitwijkmogelijkheden op MBOniveau hangen samen met de specialisatie die leerlingen ondergaan als zij binnen de beroepskolom doorleren.

\section{Rekruteringsproblemen groot voor Pedagogische, Culturele en Technische en industrieberoepen}

- Werkgevers kunnen tot 2008 zeer grote knelpunten in de personeelsvoorziening verwachten bij de Pedagogische beroepen. Hier is vooral de zeer lage instroom van afgestudeerden in combinatie met de grote vervangingsvraag debet aan. Bij de Pedagogische beroepen speelt ook een rol dat de substitutiemogelijkheden voor werkgevers, i.e. onderwijsinstellingen, beperkt zijn. Bij de Culturele beroepen en de Technische en industrieberoepen worden grote knelpunten in de personeelsvoorziening verwacht, ondanks dat voor de Technische en industrieberoepen op de middellange termijn een daling van de werkgelegenheid verwacht wordt. Over het algemeen zijn de substitutiemogelijkheden voor werkgevers tussen arbeidskrachten met een verschillende opleidingsachtergrond wat kleiner daar waar de rekruteringsproblemen op de arbeidsmarkt juist groot zijn.

- Vrijwel geen knelpunten in de personeelsvoorziening worden verwacht bij de Economisch-administratieve beroepen, Sociaal-culturele beroepen, Agrarische beroepen, Transportberoepen en Verzorgende en dienstverlenende beroepen. Met name bij de Transportberoepen, de Economischadministratieve beroepen en de Sociaal-culturele beroepen wordt dit veroorzaakt door een daling van de werkgelegenheid tezamen met een relatief lage vervangingsvraag.

\section{Arbeidsmarktintrede van Gelderse schoolverlaters verloopt redelijk goed}

- Voor Gelderse schoolverlaters van het VMBO, MBO en HBO geldt dat de arbeidsmarktintrede redelijk goed verloopt ten opzichte van het landelijke gemiddelde. Gelderse schoolverlaters leggen gemiddeld een afstand van 31 kilometer af naar hun baan, en zijn daarmee iets mobieler dan de gemiddelde schoolverlater in Nederland (28 kilometer). De inpassing in het arbeidsproces verloopt voor de Gelderse schoolverlaters doorgaans beter dan gemiddeld wat betreft het niveau en richting van de baan waarop men anderhalf jaar na afstuderen terecht komt. Zo heeft $74 \%$ van de schoolverlaters een baan op niveau gevonden. Hetzelfde geldt voor een baan in 
de eigen vakrichting. Gelderse schoolverlaters hebben echter een relatief lage kans op het vinden van een vaste of een voltijdbaan.

\section{Pendel neemt toe tussen COROP-gebieden, maar niet tussen provincies}

- In vergelijking met Nederland blijken werkenden in Gelderland echter gemiddeld iets dichter bij hun werk te wonen. Hoewel de reisafstanden en tijden zijn gestegen tussen 1991 en 2001, is de provinciegrensoverschrijdende pendel nauwelijks toegenomen in deze periode. Als de mobiliteit wordt uitgesplitst naar de vier COROP-regio's in Gelderland dan blijkt wel dat de inkomende pendel van buiten elke COROP-regio aanzienlijk is toegenomen. De oorzaak van dit patroon is dat mensen in steeds sterkere mate naar het westen gaan om te werken en dus in het oosten of noordoosten van hun werk wonen. Verder blijkt dat ook steeds meer inwoners uit Gelderland buiten hun COROP-gebied gaan werken. Inmiddels is ook in de regio Arnhem/Nijmegen de uitgaande pendel groter dan de inkomende pendel. Vooral onder hoger opgeleide mannen in ZuidwestGelderland wordt de Randstad steeds duidelijker de belangrijkste regio voor werkgelegenheid. Omgekeerd blijken mensen van buiten de provincie Gelderland vooral in Zuidwest-Gelderland te werken.

\section{Meeste inkomende pendel vanuit Overijssel}

- De grootste leverancier van werkenden in Gelderland is nu de provincie Overijssel. Vanuit Overijssel en Zuid-Holland komen meer mensen werken in Gelderland dan dat er werkenden uit Gelderland naar die provincies gaan. Voor Utrecht en Noord-Holland ligt die verhouding omgekeerd. Per saldo gaat hier een grotere stroom van mensen die in Gelderland wonen, werken in deze provincies. Bij Noord-Brabant en Limburg is de balans ongeveer in evenwicht.

\section{Grootste groei van inkomende pendel verwacht vanuit Utrecht}

- Nagegaan is welke effecten een werkgelegenheidstoename in de provincie Gelderland heeft op de inkomende pendel, de bevolkingsomvang en de participatiegraad. Ongeveer $15 \%$ van de werkgelegenheidstoename tot 2008 zal naar verwachting vervuld worden door werkenden uit naburige provincies. Het grootste deel van deze nieuwe werkenden van buiten Gelderland komt uit Utrecht $(4,3 \%)$, gevolgd door Overijssel $(3,4 \%)$ en Noord-Brabant (3,2\%). Daarnaast is de verwachting dat bijna $10 \%$ van de werkgelegenheidstoename vervuld zal worden door mensen die naar Gelderland verhuizen. De instroom van mensen die naar Gelderland verhuizen vanwege de werkgelegenheidstoename is relatief groot onder de hoger opgeleiden. 
Technische en industrieberoepen gebaat bij groter arbeidsaanbod uit naburige provincies

- Een toename van de pendelstromen of de arbeidsmarktinstroom van schoolverlaters vanuit omliggende provincies zou in sommige beroepsklassen een verlichting kunnen betekenen voor de toekomstige rekruteringsproblemen van Gelderse werkgevers. Het blijkt dat de verwachte rekruteringsproblemen voor Gelderse onderwijsinstellingen slechts in zeer beperkte mate opgelost kunnen worden door verschuivingen in het regionale arbeidsaanbod te bewerkstelligen, temeer omdat de knelpunten voor de Pedagogische beroepen in de rest van Nederland nog groter zijn.

- Voor de Technische en industrieberoepen geldt dat een stijging van $1 \%$ van het arbeidsaanbod van inkomende pendelaars of schoolverlaters leidt tot het oplossen van de knelpunten in de personeelsvoorziening in Gelderland. Dit is een aantrekkelijke optie, mede omdat de rekruteringsproblemen voor de Technische en industrieberoepen kleiner zijn in de rest van Nederland dan in Gelderland. Voor de Culturele beroepen is dit moeilijker, omdat de vereiste verandering in het regionale Gelderse arbeidsaanbod groter is. Bovendien zijn er voor deze beroepen ook enige knelpunten in de personeelsvoorziening in de rest van Nederland. 


\section{De Gelderse arbeidsmarkt in vogelvlucht}

De oververtegenwoordiging van de Gelderse werkgelegenheid in de Technische, ambachts- en industrieberoepen hangt samen met de relatief grote omvang van de werkgelegenheid in de bedrijfssectoren Overige industrie, Voeding, Bouw en onroerend goed en Handel en reparatie. De relatief grote werkgelegenheid in de Agrarische beroepen en de Technische, ambachts- en industrieberoepen lijkt vooral gebaseerd te zijn op het grote aantal lager en middelbaar opgeleiden met een agrarische of technische achtergrond, terwijl de oververtegenwoordiging van de werkgelegenheid in de Medische en paramedische beroepen vooral gebaseerd lijkt te zijn op het grote aandeel hoger opgeleiden met een (para)medische opleidingsachtergrond. De werkgelegenheid is laag ten opzichte van Nederland binnen de Openbare orde- en veiligheidsberoepen, de Culturele beroepen en de Informaticaberoepen. Verder blijkt dat de stijging van de Gelderse werkgelegenheid tussen 1998 en 2002 zich vooral heeft geconcentreerd bij de universitair opgeleiden.

In totaal zijn er in Gelderland ongeveer 240.000 personen aan het werk die geen startkwalificatie - minimaal MBO-niveau - voor de arbeidsmarkt hebben. Deze ongeschoolden en laag opgeleiden - ruim een kwart van de werkzame beroepsbevolking in Gelderland - zijn qua competenties minder goed toegerust om bij technologische en organisatorische veranderingen te kunnen blijven functioneren. Om te voorkomen dat deze personen als gevolg daarvan uiteindelijk zelfs de arbeidsmarkt de rug toekeren, is het noodzakelijk hen tijdig te begeleiden naar een hoger baanniveau door bijv. 'learning-by-doing' in banen met een hoge 'learning content' in combinatie met aanvullende scholing ('training-on-the-job').

De totale verwachte werkgelegenheidsgroei van 2003 tot 2008 in Gelderland bedraagt $1 \%$ van de werkgelegenheid in 2002. De verwachte werkgelegenheidsgroei leidt tezamen met de arbeidsmarktuitstroom ten gevolge van onder meer pensionering, de uitstroom vanwege ziekte of arbeidsongeschiktheid en de tijdelijke uittrede van vrouwen, tot het totaal aan baanopeningen in Gelderland. Het aantal baanopeningen tot 2008 bedraagt naar verwachting $27 \%$ van de werkgelegenheid in 2002. Omdat de regionale instroom van schoolverlaters op de arbeidsmarkt naar verwachting 23\% zal zijn, moet er in 2008 rekening worden gehouden met een vraagoverschot op de Gelderse arbeidsmarkt.

Het procentuele vraagoverschot voor Gelderland is groter dan voor Nederland. Dit komt waarschijnlijk vooral door de uitstroom van ouderen, en de relatief sterk vergrijzing in Gelderland. In Gelderland is $20 \%$ tot $21 \%$ van de werkzame beroepsbevolking tussen 50 en 65 jaar oud. Alleen voor de provincies Friesland, Limburg en Zeeland is de vergrijzing groter. De uitstroom van ouderen leidt echter niet vanzelf tot vervangingsvraag. In sommige vergrijsde sectoren, zoals de landbouw en de textielindustrie, wordt de uitstroom van ouderen vaak aangegrepen om het personeelsbestand in te krimpen. Een daling van de werkgelegenheid van 
sectoren of beroepsgroepen in die sectoren gaat dan gepaard met een relatief grote uitstroom zonder dat daar baanopeningen voor schoolverlaters tegenover staan.

\section{$1.1 \quad$ Inleiding}

Voor een beter inzicht in de Gelderse werkgelegenheidsontwikkeling wordt in paragraaf 1.2 eerst stilgestaan bij een aantal kenmerken van de werkgelegenheid van de beroepsbevolking in Gelderland naar sector, beroep en opleiding. ${ }^{3}$ In paragraaf 1.3 wordt vervolgens ingegaan op de verwachte arbeidsmarktontwikkelingen in Gelderland op hoofdlijnen. Ook komt de invloed van de vergrijzing van de Gelderse beroepsbevolking op de toekomstige vraag naar arbeidskrachten aan de orde.

\subsection{Kenmerken en ontwikkeling van de werkzame beroepsbevolking in Gelderland}

Tabel 1.1 geeft aan in welke bedrijfssectoren de beroepsbevolking van Gelderland werkzaam is. De grootste bedrijfssectoren zijn de dienstensectoren Handel en reparatie, Horeca en zakelijke dienstverlening (incl. uitzendwezen), Kwartaire diensten (incl. gezondheidszorg) en Overheid en onderwijs. In deze sectoren werken in totaal ongeveer een half miljoen mensen, hetgeen circa $60 \%$ de werkzame beroepsbevolking van Gelderland is. In de laatstgenoemde drie sectoren is bovendien een stijgende werkgelegenheidstrend waarneembaar. Ten opzichte van Nederland zijn er in Gelderland relatief veel werkenden in de Overige industrie (waaronder textiel-, hout-, paperindustrie en grafische industrie), en in de industriesector Voeding. Ook de werkgelegenheid in Bouw en onroerend goed en Handel en reparatie is in Gelderland oververtegenwoordigd.

In tabel 1.2 is de Gelderse werkgelegenheid naar beroepsklasse weergegeven. De grootste beroepsklassen zijn de Economische-administratieve beroepen, de Technische, ambachts- en industrieberoepen en de Verzorgende en dienstverlenend beroepen. De werkgelegenheid in de verschillende beroepsklassen weerspiegelt deels de beroepensamenstelling van de bedrijfssectoren. Zo zien we ten opzichte van Nederland een oververtegenwoordiging van de Gelderse werkgelegenheid in de Technische, ambachts- en industrieberoepen. Dit hangt samen met de relatief grote omvang van de werkgelegenheid in de bedrijfssectoren Overige industrie, Voeding, Bouw en onroerend goed en Handel en reparatie.

3. Zie voor een uitgebreide beschrijving van de structuur en de ontwikkeling van de werkgelegenheid in Gelderland: Bureau Economisch Onderzoek (2004), Provinciale Economische Verkenning, provincie Gelderland, Arnhem. Daarnaast bevat de digitale statistische bijlage - RAMING Digitaal (zie Bijlage C) - van het voorliggende rapport tevens een uitgebreide weergave van de diverse achtergrondkenmerken van de werkzame personen en hun baankenmerken. 
Tabel 1.1

Werkzame beroepsbevolking in Gelderland naar bedrijfssector, gemiddelde 2001-2002

\begin{tabular}{|c|c|c|c|}
\hline Bedrijfssector & $\begin{array}{r}\text { Aantal } \\
\text { werkenden }\end{array}$ & $\begin{array}{l}\text { Typering } \\
\text { t.o.v. } \\
\text { Nederland }\end{array}$ & $\begin{array}{l}\text { Trend } \\
\text { 1998-2002 }\end{array}$ \\
\hline Landbouw en visserij & 22.500 & gemiddeld & dalend \\
\hline Voeding & 21.000 & hoog & constant \\
\hline Chemie & 12.000 & laag & dalend \\
\hline Metaal en elektrotechniek & 50.000 & gemiddeld & constant \\
\hline Overige industrie & 51.500 & erg hoog & constant \\
\hline Energie & 5.000 & erg laag & dalend \\
\hline Bouw en onroerend goed & 72.000 & hoog & constant \\
\hline Handel en reparatie & 132.500 & hoog & constant \\
\hline Transport en communicatie & 42.000 & erg laag & constant \\
\hline Bank- en verzekeringswezen & 30.000 & gemiddeld & constant \\
\hline Horeca en zakelijke dienstverlening & 124.500 & laag & stijgend \\
\hline Kwartaire diensten & 144.500 & gemiddeld & stijgend \\
\hline Overheid en onderwijs & 122.000 & gemiddeld & stijgend \\
\hline Totaal (incl. overig) & 848.500 & & constant \\
\hline
\end{tabular}

Bron: CBS/ROA

Tabel 1.2

Werkzame beroepsbevolking in Gelderland naar beroepsklasse, gemiddelde 2001-2002

\begin{tabular}{|c|c|c|c|}
\hline Beroepsklasse & $\begin{array}{r}\text { Aantal } \\
\text { werkenden }\end{array}$ & $\begin{array}{l}\text { Typering } \\
\text { t.o.v. } \\
\text { Nederland }\end{array}$ & $\begin{array}{l}\text { Trend } \\
\text { 1998-2002 }\end{array}$ \\
\hline Pedagogische beroepen & 45.000 & gemiddeld & constant \\
\hline Culturele beroepen & 13.500 & laag & constant \\
\hline Agrarische beroepen & 29.000 & hoog & dalend \\
\hline Technische, ambachts- en industrieberoepen & 188.000 & hoog & constant \\
\hline Transportberoepen & 50.500 & hoog & constant \\
\hline Medische en paramedische beroepen & 54.000 & erg hoog & stijgend \\
\hline Economisch-administratieve beroepen & 241.000 & gemiddeld & stijgend \\
\hline Informatica beroepen & 30.500 & laag & stijgend \\
\hline Sociaal-culturele beroepen & 28.000 & gemiddeld & constant \\
\hline Verzorgende en dienstverlenende beroepen & 135.000 & gemiddeld & constant \\
\hline Openbare orde- en veiligheidsberoepen & 12.000 & erg laag & stijgend \\
\hline Totaal (incl. overig) & 848.500 & & constant \\
\hline
\end{tabular}

Bron: CBS/ROA

Toch is er niet altijd een dergelijke directe relatie te leggen. De relatief grote werkgelegenheid in de Medische en paramedische beroepen en de Agrarische beroepen is niet eenvoudig te verklaren uit de sectorale werkgelegenheidscompositie. De werkgelegenheid is erg laag binnen de Openbare orde- en veiligheidsberoepen (waaronder politie- en brandweerpersoneel, zie bijlage B). Verder is 
er ook een ondervertegenwoordiging van de werkgelegenheid in de Culturele beroepen (waaronder bijv. tolken, vertalers en schrijvers, bibliothecarissen, geestelijken en journalisten) en de Informaticaberoepen.

In tabel 1.3 is de werkgelegenheid naar opleidingscategorie weergegeven. Opvallend is dat de oververtegenwoordiging van de werkgelegenheid in de Agrarische beroepen en de Technische, ambachts- en industrieberoepen vooral gebaseerd lijkt te zijn op het grote aantal lager en middelbaar opgeleiden met een agrarische of technische achtergrond, dat wil zeggen werkenden met een opleidingsachtergrond in (V)MBO Natuur en techniek. Opvallend is verder de relatief grote werkgelegenheid van hoger opgeleiden in de (para)medische richting. Uit tabel 1.3 blijkt tevens dat de stijging van de werkgelegenheid tussen 1998 en 2002 zich vooral heeft geconcentreerd bij de universitair opgeleiden.

Tabel 1.3

Werkzame beroepsbevolking in Gelderland naar opleidingscategorie, gemiddelde 2001-2002

\begin{tabular}{|c|c|c|c|}
\hline Opleidingscategorie & $\begin{array}{r}\text { Aantal } \\
\text { werkenden }\end{array}$ & $\begin{array}{l}\text { Typering } \\
\text { t.o.v. } \\
\text { Nederland }\end{array}$ & $\begin{array}{l}\text { Trend } \\
\text { 1998-2002 }\end{array}$ \\
\hline Basisonderwijs & 64.000 & laag & constant \\
\hline VMBO Theorie & 55.000 & gemiddeld & constant \\
\hline VMBO Natuur en techniek & 68.000 & erg hoog & constant \\
\hline VMBO Economie & 21.500 & gemiddeld & constant \\
\hline VMBO Verzorging & 28.000 & hoog & constant \\
\hline HAVO/VWO & 38.000 & erg laag & stijgend \\
\hline MBO Natuur en techniek & 116.500 & hoog & constant \\
\hline MBO Economie & 119.000 & gemiddeld & constant \\
\hline MBO Dienstverlening en gezondheidszorg & 86.000 & gemiddeld & constant \\
\hline HBO Natuur en techniek & 33.500 & gemiddeld & constant \\
\hline HBO Economie & 41.500 & gemiddeld & stijgend \\
\hline HBO Onderwijs en sociaal-cultureel & 61.500 & laag & constant \\
\hline HBO Paramedisch & 16.500 & erg hoog & constant \\
\hline WO Natuur en techniek & 15.000 & laag & constant \\
\hline WO Economie & 16.500 & erg laag & stijgend \\
\hline WO Letteren en sociaal-cultureel & 21.500 & hoog & stijgend \\
\hline WO Medisch & 9.000 & hoog & stijgend \\
\hline Totaal (incl. overig) & 848.500 & & constant \\
\hline
\end{tabular}

Bron: CBS/ROA

In totaal zijn er in Gelderland ongeveer 240.000 personen aan het werk die geen startkwalificatie - minimaal MBO-niveau - voor de arbeidsmarkt hebben. Dat is ruim een kwart van de werkzame beroepsbevolking. Deze ongeschoolden en laag opgeleiden zijn qua competenties minder goed toegerust om bij technologische en organisatorische veranderingen op de arbeidsmarkt te kunnen blijven functioneren. Doorgaans zijn de loopbaanperspectieven van deze personen minder goed, en lopen ze ook een groter dan gemiddelde kans om werkloos te worden. Om te voorkomen dat deze personen als gevolg daarvan uiteindelijk zelfs de arbeidsmarkt de rug 
toekeren, is het noodzakelijk hen tijdig te begeleiden naar een hoger baanniveau. ${ }^{4}$ Dit is bijvoorbeeld mogelijk door in de baan die ze vervullen leerelementen in te bouwen. Door 'learning-by-doing' in banen met een hoge 'learning content' in combinatie met aanvullende scholing ('training-on-the-job') kan er op termijn een hoger productiviteitsniveau worden behaald. Dit kan de doorstroom bevorderen binnen het bedrijf waar ze werken, of hen ertoe aanzetten om op de externe arbeidsmarkt een betere baan te vinden.

\subsection{De verwachte arbeidsmarktontwikkelingen in Gelderland op hoofdlijnen}

Tabel 1.4 laat zien dat de verwachte werkgelegenheidsgroei tot 2008 in Gelderland $1 \%$ van de werkgelegenheid in 2002 bedraagt. ${ }^{5}$ De verwachte werkgelegenheidsgroei leidt tezamen met de arbeidsmarktuitstroom ten gevolge van onder meer pensionering, de uitstroom vanwege ziekte of arbeidsongeschiktheid en de tijdelijke uittrede van vrouwen, tot het totaal aan baanopeningen in Gelderland. Het aantal baanopeningen tot 2008 bedraagt naar verwachting $27 \%$ van de werkgelegenheid in 2002. Omdat de regionale instroom van schoolverlaters op de arbeidsmarkt naar verwachting 23\% zal zijn, moet er in 2008 rekening worden gehouden met een vraagoverschot op de Gelderse arbeidsmarkt.

Het vraagoverschot op de arbeidsmarkt uitgedrukt in procenten van de werkgelegenheid in 2002 is voor Gelderland groter dan voor Nederland als totaal. ${ }^{6}$ Het vraagoverschot geeft een indicatie van de totale verwachte toekomstige kwantitatieve discrepantie op de arbeidsmarkt. Op de verschillende segmenten van de arbeidsmarkt kunnen zich echter uiteenlopende 'mismatches' tussen opleiding en beroep voordoen. De verwachte afnemende krapte op de arbeidsmarkt op macroniveau ten opzichte van de laatste jaren zegt dus nog weinig over de verwachte vraag- en aanbodverhoudingen op het niveau van specifieke opleidingen en beroepen. Derhalve worden in dit rapport de verwachte knelpunten en perspectieven nader gedifferentieerd naar beroep en opleiding.

4. Zie ook hoofdstuk 5 in $\mathrm{ROA}(2003)$, De arbeidsmarkt naar opleiding en beroep tot 2008 , ROA-R-2003/11, Maastricht.

5. De verwachte werkgelegenheidsgroei in deze rapportage is gebaseerd op prognoses van het Bureau Economisch Onderzoek (BEO) van de provincie Gelderland. Het Nederlandse referentiekader voor de Gelderse prognoses wordt gevormd door de landelijke sectorontwikkeling zoals weergegeven in de studie De arbeidsmarkt naar opleiding en beroep tot 2008 van het ROA. De hierin weergegeven landelijke prognoses zijn voor de Gelderse prognoses het uitgangspunt geweest voor de provinciale modeldoorrekening. Voor een verantwoording van de landelijke middellangetermijnprognoses, zie ROA(2003), De arbeidsmarkt naar opleiding en beroep tot 2008, ROA-R-2003/11, Maastricht.

6. Van belang is dat in dit rapport de begrippen 'werkgelegenheid' en 'werkzame beroepsbevolking' doorgaans als synoniemen worden gebruikt. Het gaat hierbij om de personen die deel uitmaken van de Gelderse bevolking, en binnen of buiten Gelderland werkzaam zijn. In hoofdstuk 5 wordt nader ingegaan op de pendelstromen tussen de verschillende provincies en andere vormen van regionale interactie. 
Tabel 1.4

Verwachte macro-arbeidsmarktontwikkeling voor vijfjaarsperiode, als percentage van de werkgelegenheid in 2002, Gelderland en Nederland

\begin{tabular}{|c|c|c|}
\hline Kenmerk & $\begin{array}{r}\text { Gelderland } \\
2003-2008 \\
\%\end{array}$ & $\begin{array}{r}\text { Nederland } \\
2003-2008 \\
\%\end{array}$ \\
\hline Werkgelegenheidsgroei & 1 & 1 \\
\hline Arbeidsmarktuitstroom & 26 & 23 \\
\hline Baanopeningen & 27 & 24 \\
\hline Instroom schoolverlaters & 23 & 22 \\
\hline Vraagoverschot & 4 & 2 \\
\hline
\end{tabular}

Bron: BEO/CPB/ROA

Het weergegeven vraagoverschot voor de middellange termijn in tabel 1.4 vertaalt zich bovendien niet zonder meer in een neerwaartse aanpassing van de werkloosheid. Als gevolg van de verwachte 'gap' tussen vraag en aanbod op de arbeidsmarkt kunnen zich verschillende aanpassingsprocessen gaan afspelen. ${ }^{7}$ Zo kan een toenemende spanning op een bepaald arbeidsmarktsegment leiden tot een (relatieve) loonaanpassing naar boven, waardoor de vraag naar arbeid daalt en het aanbod van arbeid toeneemt. Dit aanpassingsproces kan tevens gedifferentieerd plaatsvinden op de verschillende segmenten van de arbeidsmarkt, omdat de vraagoverschotten niet overal even groot zijn. Voor sommige segmenten kunnen ook aanbodoverschotten bestaan, welke kunnen worden opgelost door neerwaartse loonaanpassingen maar ook door een additionele vraag naar arbeidskrachten vanuit aanverwante arbeidsmarktsegmenten waarvoor vraagoverschotten bestaan. Daarnaast kunnen werkgevers bij een vraagoverschot hun kwalificatievereisten naar beneden bijstellen, en kunnen schoolverlaters en werkzoekenden bij een aanbodoverschot solliciteren in een andere vakrichting of op een lager functieniveau dan zij aanvankelijk wensten, of zich laten bij- of omscholen. Andere aanpassingsprocessen zijn onder andere ontmoedigings- en aanmoedigingseffecten van degenen die niet actief zoeken naar een baan. Deze zogenaamde 'stille reserve' kan in de loop der tijd meedeinen met de toe- en afname van de vraag naar personeel. ${ }^{8}$ Hierdoor zullen bijvoorbeeld vrouwelijke potentiële herintreders hun arbeidsmarktintrede bij een neergaande conjunctuur uitstellen totdat de conjunctuur en de arbeidsmarktsituatie weer verbeteren. Ook het deelnemen aan een vervolgopleiding door schoolverlaters als alternatief voor de arbeidsmarktintrede, valt onder de ontmoedigingseffecten.

7. (Zie voor de interpretatie van vraag- en aanbodoverschotten L. Borghans and E. Willems 1998), 'Interpreting gaps in manpower forecasting models', Labour, Vol. 12, pp. 633-641.

8. Zie voor deze ontmoedigings- en aanmoedigingseffecten bijvoorbeeld J. Darby, R.A. Hart and M. Vecchi (2001), 'Labour force participation and the business cycle: a comparative analysis of France, Japan, Sweden and the United States', Japan and the World Economy, Vol. 13, pp. 113-133.

6 
De genoemde aanpassingsprocessen gaan gepaard met kosten. Voor werkzoekenden kunnen aanpassingskosten een rol spelen als op hun arbeidsmarktsegment de schaarste aan personeel afneemt en het aanbod de vraag overtreft. Deze aanpassingskosten hebben niet alleen betrekking op het accepteren van een langere zoekduur om een baan te vinden, maar ook op het accepteren van een baan met slechtere arbeidsvoorwaarden of een baan buiten de regio van de eerste voorkeur (zie hoofdstuk 5 van dit rapport over mobiliteit). Een lager loon voor baanvinders kan een lagere productiviteit weerspiegelen omdat de baan minder goed aansluit bij de eigen opleidings- en ervaringsachtergrond. Andere kosten voor werkzoekenden zijn eventuele om- en bijscholingskosten, gederfde inkomsten door het uitstellen van de intrede op de arbeidsmarkt, hogere reiskosten en verhuiskosten, en de (psychische en sociale) kosten die gepaard gaan met het accepteren van een baan in het buitenland.

Ook werkgevers maken aanpassingskosten als ze besluiten om bij een vraagoverschot personeel aan te nemen dat niet helemaal voldoet aan de eerder gestelde criteria, of als ze hun personeel in het buitenland moeten rekruteren. Daarnaast kunnen werkgevers besluiten om hun productieproces anders in te richten: zowel wat betreft de verdeling van taken behorende bij functies die moeilijk vervulbaar zijn, als wat betreft de kapitaalintensiteit van het productieproces - denk aan automatisering en investeringen in machines - kunnen werkgevers oplossingen zoeken voor de knelpunten in de personeelsvoorziening. Ook deze maatregelen gaan gepaard met investerings- of reorganisatiekosten. De meest rigoureuze oplossing voor werkgevers is het (gedeeltelijk) stoppen van de productie of het verplaatsen van de bedrijfsactiviteiten naar het buitenland.

Uit tabel 1.4 blijkt verder dat het vraagoverschot als percentage van de werkgelegenheid in 2002 voor Gelderland groter is dan voor Nederland. Dit komt waarschijnlijk vooral door de uitstroom van ouderen, en de relatief sterk vergrijzing in Gelderland. ${ }^{9}$ Dit wordt duidelijk uit figuur 1.1. Deze figuur geeft aan de hand van de kaart van Nederland aan hoe groot het aandeel ouderen in de werkzame beroepsbevolking van elke provincie is. In Gelderland is $20 \%$ tot $21 \%$ van de werkzame beroepsbevolking tussen 50 en 65 jaar oud. Alleen voor de provincies Friesland, Limburg en Zeeland is de vergrijzing groter. De provincies Utrecht en Flevoland hebben het kleinste percentage ouderen van de werkzame beroepsbevolking, en daardoor naar verwachting ook de kleinste uitstroom van ouderen. De uitstroom van ouderen leidt echter niet vanzelf tot vervangingsvraag. In sommige vergrijsde sectoren, zoals de landbouw en de textielindustrie, wordt de uitstroom van ouderen vaak aangegrepen om het personeelsbestand in te krimpen. Een daling van de werkgelegenheid van sectoren of beroepsgroepen in die sectoren gaat dan gepaard met een relatief grote uitstroom zonder dat daar baanopeningen voor schoolverlaters tegenover staan. ${ }^{10}$

9. Zie ook Provincie Gelderland (2004), Sociale atlas Gelderland; Sociaal rapport met een beschrijving van de sociale staat van de Gelderse wijken, gemeenten en regio's, Arnhem.

10. Zie voor een analyse van vergrijzing en vervanging op sectoraal en provinciaal niveau aan de hand van ROA-gegevens: RWI (2004), Vergrijzing en vervanging: Een analyse van de gevolgen van het uitstromen van de babyboomgeneratie voor de arbeidsmarkt, Raad voor Werk en Inkomen, Den Haag. 
Figuur 1.1

Percentage ouderen (50-64 jaar) van de werkzame beroepsbevolking per provincie, gemiddelde 2001-2002
Meer dan $21 \%$
Tussen $20 \%$ en $21 \%$
Tussen $19,5 \%$ en $20 \%$
Minder dan $19,5 \%$

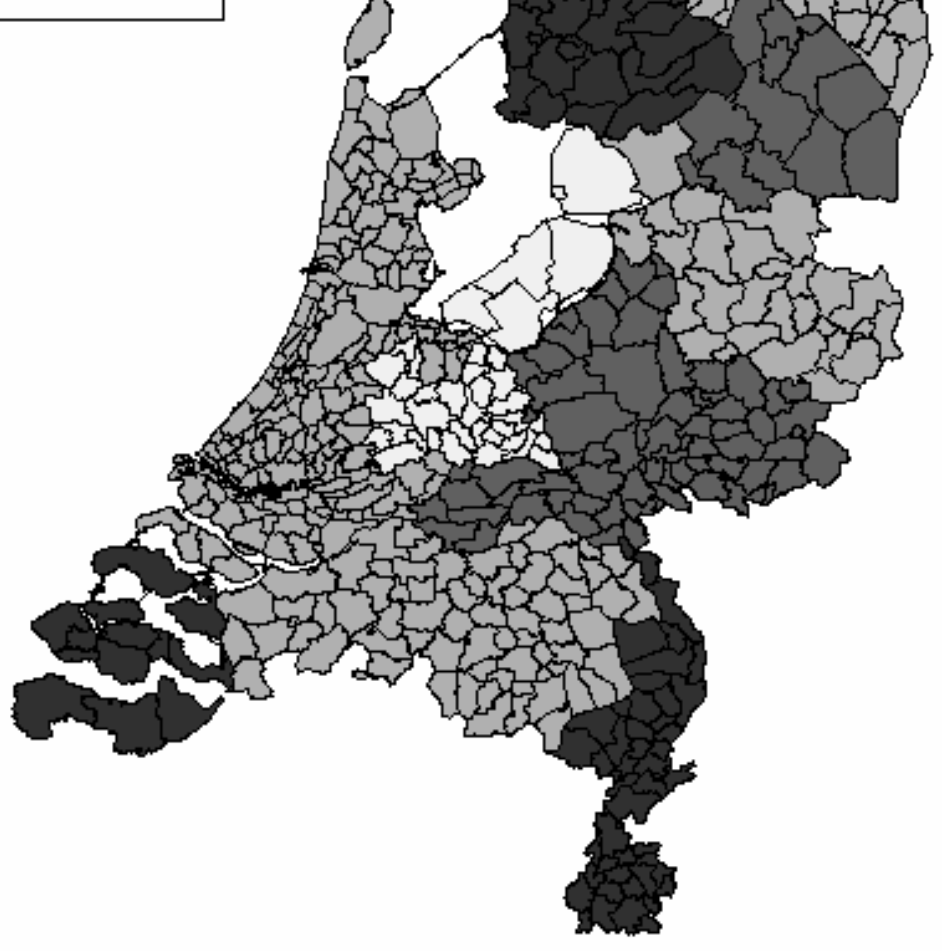




\section{Deelname aan onderwijs en aanbod van schoolverlaters}

Het aanbod op de regionale arbeidsmarkt wordt voor een belangrijk deel bepaald door gediplomeerden van het voorgezet en middelbaar onderwijs. Leerlingen van het VMBO, MBO en HAVONWO die na het behalen van het diploma niet doorstuderen, zullen meestal de arbeidsmarkt betreden. Bovendien dient er rekening te worden gehouden met 'drop outs' van het VMBO, die zonder enig diploma op de arbeidsmarkt instromen. Om het aanbod op de regionale arbeidsmarkt in kaart te brengen wordt gekeken naar de arbeidsmarktinstroom tot 2008 als percentage van de werkende beroepsbevolking. De arbeidsmarktinstroom van MBO'ers ligt voor Gelderland over het algemeen even hoog als voor Nederland. In overeenstemming met het landelijke beeld heeft VMBO economie een veel hoger dan gemiddelde arbeidsmarktinstroom, en MBO Natuur en techniek een lager dan gemiddelde arbeidsmarktinstroom. Opmerkelijk is verder de ten opzichte van Nederland relatief grote arbeidsmarktinstroom van schoolverlaters zonder enig diploma op de Gelderse arbeidsmarkt.

In 2003 hebben 13.200 VMBO'ers hun opleiding succesvol afgerond. Ongeveer een derde deel van de VMBO'ers heeft de theoretische leerweg gevolgd. Met name VMBO Economie en VMBO Verzorging zijn gedurende de laatste jaren populairder geworden, ten koste van VMBO Natuur en techniek. In 2003 hebben ongeveer 13.400 MBO'ers hun diploma gehaald. MBO Dienstverlening en gezondheidszorg heeft het grootste aandeel onder de gediplomeerden in het middelbaar beroepsonderwijs (38\%), gevolgd door MBO Natuur en techniek (34\%) en MBO Economie (26\%). Het aandeel MBO'ers met een diploma Natuur en techniek op zak is aan het afnemen. In 2003 had Dienstverlening en Gezondheidszorg de meeste MBOgediplomeerden, terwijl in 1998 Natuur en techniek nog de meeste gediplomeerden van het MBO afleverde. De hierboven geconstateerde lage verwachte toekomstige arbeidsmarktinstroom voor MBO Natuur en techniek is in overeenstemming met de achterblijvende belangstelling voor deze richting onder leerlingen van het $M B O$.

Leerlingen in het MBO kunnen hun diploma halen via de meer praktisch georiënteerde beroepsbegeleidende leerweg (BBL, het voormalige leerlingwezen) of via de meer theoretisch georiënteerde beroepsopleidende leerweg (BOL). Het aandeel BBL-gediplomeerden is het grootst in MBO Natuur en techniek (59\%) en het kleinst in MBO Economie (23\%).

\section{$2.1 \quad$ Inleiding}

In dit hoofdstuk zullen de deelname van leerlingen en de uitstroom van gediplomeerden van het voortgezet onderwijs en het beroepsonderwijs in Gelderland in kaart worden gebracht. Daarnaast wordt een indicatie gegeven van de toekomstige instroom op de arbeidsmarkt vanuit het onderwijs. De opzet van dit hoofdstuk is als volgt. In paragraaf 2.2 wordt aandacht geschonken aan het aantal leerlingen dat gedurende de afgelopen jaren een VMBO-opleiding, een HAVO/VWO-opleiding of 
een opleiding aan een Gelders Regionaal Opleidingscentrum (ROC) of Agrarisch Opleidingscentrum (AOC) succesvol heeft afgerond. In paragraaf 2.3 wordt ingegaan op het aantal leerlingen dat momenteel in Gelderland een opleiding op VMBO-, HAVO/VWO- of MBO-niveau volgt, en in paragraaf 2.4 wordt de voorspelde arbeidsmarktinstroom van schoolverlaters besproken.

\subsection{Gediplomeerden in Gelderland ${ }^{11}$}

In tabel 2.1 wordt een overzicht gegeven van het aantal gediplomeerden van het voortgezet en middelbaar onderwijs in Gelderland. Uit de tabel blijkt dat 13.200 VMBO'ers hun opleiding in 2003 succesvol hebben afgerond. Ten opzichte van 1998 is voor alle richtingen een stijgende lijn in het aantal gediplomeerde VMBO'ers zichtbaar, met uitzondering van VMBO Theorie. Het aandeel gediplomeerden in de theoretische leerweg binnen het VMBO is afgenomen ten faveure van de beroepsgerichte opleidingen binnen het $\mathrm{VMBO}$.

Verder laat tabel 2.1 zien dat er in Gelderland in 2003 ongeveer 13.400 MBO'ers hun opleiding succesvol hebben afgerond. Afgestudeerde Gelderse MBO'ers hebben het vaakst een opleiding in de richting MBO Dienstverlening en gezondheidszorg gevolgd. Het aantal MBO-gediplomeerden is tussen 1998 en 2003 over het algemeen toegenomen, behalve voor $M B O$ Natuur en techniek. Ook het aantal gediplomeerden van het HAVONWO is afgenomen.

Tabel 2.1

Aantal gediplomeerden van het VMBO en het MBO naar opleidingscategorie en leerweg, Gelderland

\begin{tabular}{|c|c|c|c|}
\hline & 1998 & 2003 & $\begin{array}{r}\text { BBL in } 2003 \\
\%\end{array}$ \\
\hline VMBO Theorie & 5.630 & 4.520 & - \\
\hline VMBO Natuur en techniek & 3.780 & 3.920 & - \\
\hline VMBO Verzorging & 1.710 & 2.430 & - \\
\hline VMBO Economie & 1.600 & 2.180 & - \\
\hline VMBO Totaal (incl. overig) & 12.720 & 13.200 & - \\
\hline HAVO/VWO & 7.380 & 7.210 & - \\
\hline MBO Natuur en techniek & 4.640 & 4.500 & 59 \\
\hline MBO Dienstverlening en gezondheidszorg & 4.040 & 5.110 & 45 \\
\hline MBO Economie & 2.920 & 3.510 & 23 \\
\hline MBO Totaal (incl. overig) & 11.620 & 13.430 & 44 \\
\hline
\end{tabular}

Bron: ROA/CBS

Voor veel MBO-opleidingen bestaat de mogelijkheid om ofwel de meer theoretisch gerichte beroepsopleidende leerweg (BOL), ofwel de meer praktische georiënteerde

11. De gegevens over gediplomeerden zijn afkomstig van het CBS. De jaartallen die genoemd worden bij de aantallen gediplomeerden hebben betrekking op het jaar van afstuderen. Het jaar 2003 duidt derhalve op het schooljaar 2002/2003. 
beroepsbegeleidende leerweg (BBL, het voormalige leerlingwezen) te volgen. De beroepsbegeleidende leerweg bestaat uit een combinatie van leren en werken.

Doorgaans gaat men één dag per week naar school, en werkt men vier dagen per week bij een bedrijf of instelling. Voor het creëren van leerlingplaatsen (Beroepspraktijkvormingsplaatsen, BPV) is de medewerking van werkgevers in de regio noodzakelijk. Ongeveer 44\% van de MBO-gediplomeerden heeft een BBL-opleiding gevolgd. Het aandeel BBL'ers is het grootst onder gediplomeerden met een diploma Natuur en techniek, waar bijna $60 \%$ van de gediplomeerden heeft gekozen voor de beroepsbegeleidende leerweg. Binnen MBO Economie is daarentegen een BOLopleiding het populairst: $77 \%$ van de gediplomeerden heeft een BOL-opleiding gevolgd.

In figuur 2.1 wordt de ontwikkeling van het aandeel gediplomeerden per opleidingscategorie van het VMBO getoond. De figuur laat zien dat het aandeel gediplomeerden VMBO Natuur en techniek als percentage van het totaal aantal VMBO'ers met een diploma van een beroepsopleiding (excl. VMBO Theorie) in 2003 lager is dan in 1998. Dit betekent dat de stijging van het aantal gediplomeerden groter is geweest voor VMBO Verzorging en VMBO Economie dan voor VMBO Natuur en techniek.

Figuur 2.1

VMBO-gediplomeerden naar opleidingscategorie, percentage van het totale aantal VMBOgediplomeerden (excl. VMBO theorie), Gelderland

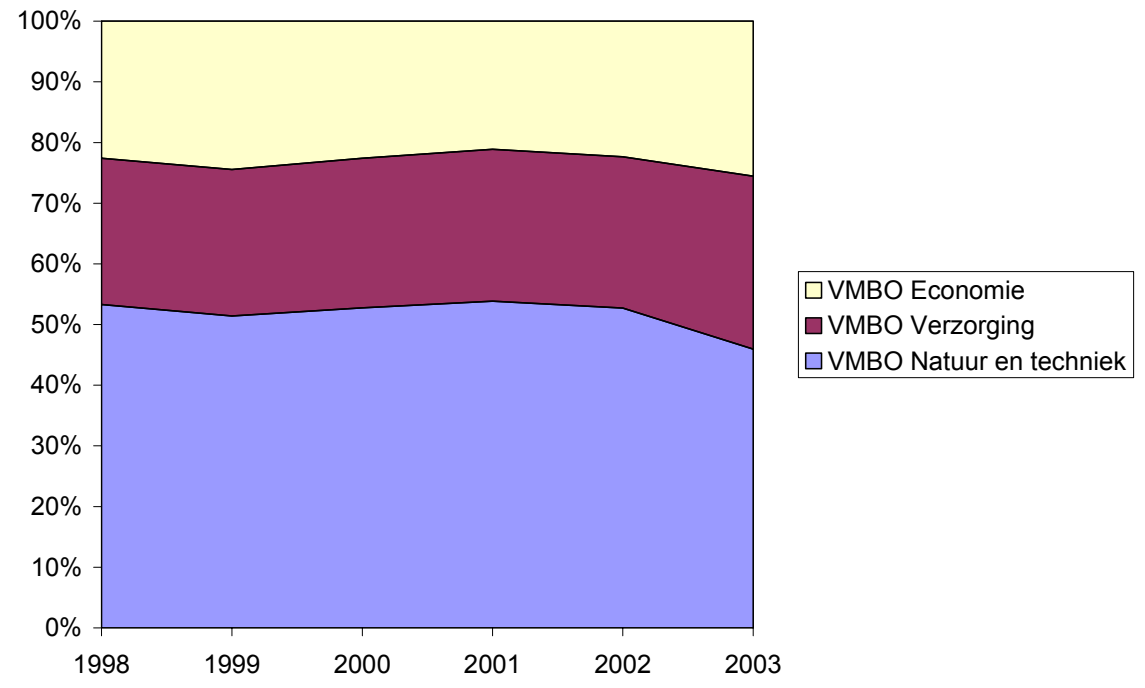

Bron: ROA/CBS

Figuur 2.2 laat de gediplomeerden zien met een MBO-opleiding. Het aandeel MBOafgestudeerden met een diploma Natuur en techniek is kleiner geworden tussen 1998 en 2003. Voor de overige twee opleidingscategorieën is het aandeel juist toegenomen. In 2003 had Dienstverlening en Gezondheidszorg de meeste gediplo- 
meerden, terwijl in 1998 Natuur en techniek nog de meeste gediplomeerden afleverde.

\section{Figuur 2.2}

MBO-gediplomeerden naar opleidingscategorie, percentage van het totale aantal MBOgediplomeerden, Gelderland

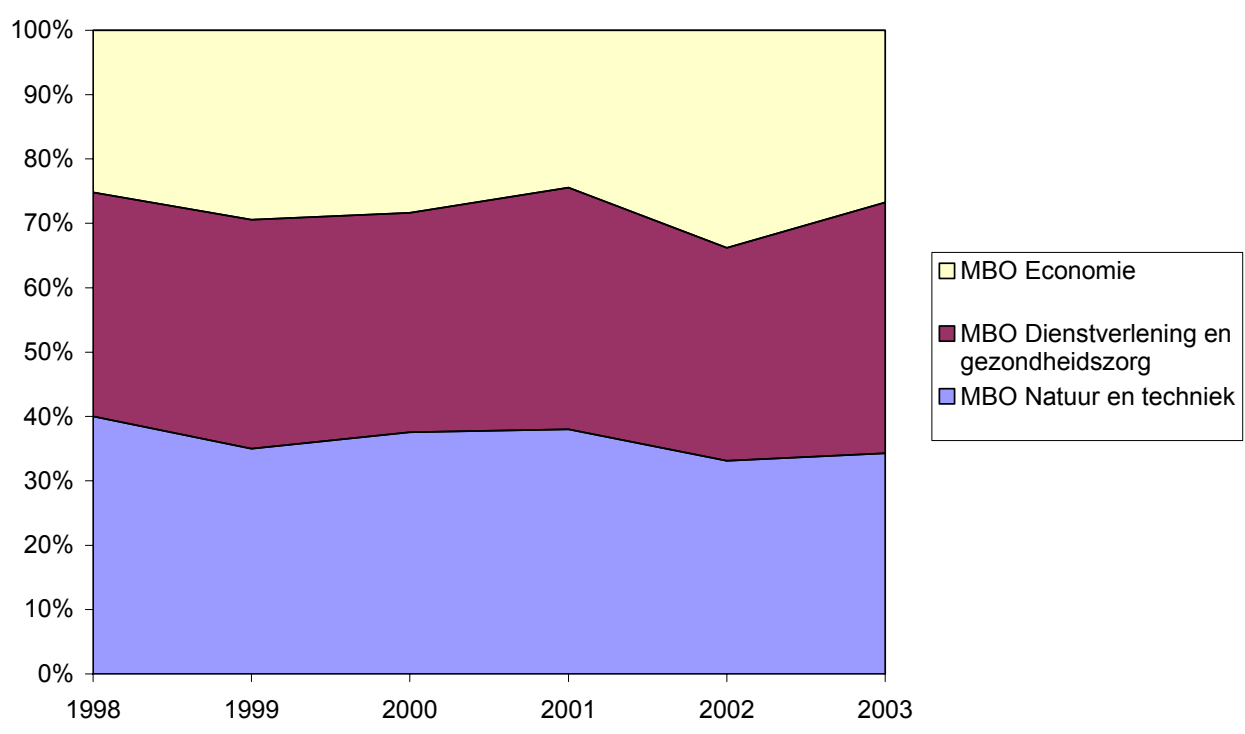

Bron: ROA/CBS

\subsection{Leerlingen in Gelderland ${ }^{12}$}

Aan de hand van een overzicht van het aantal leerlingen in Gelderland kan een eerste indicatie worden gegeven van het te verwachten toekomstige arbeidsaanbod in de regio. Het overgrote deel van de VMBO-leerlingen (meer dan 56.000 leerlingen) volgt de theoretische leerweg of zit in de eerste twee jaar van de opleiding (de zogenaamde basisvorming). Op het MBO was in 2003 de richting Dienstverlening en Gezondheidszorg het populairst onder de leerlingen. In 1998 volgde het grootste aantal MBO-leerlingen nog een opleiding in de richting Natuur en techniek.

Ongeveer een derde deel van de Gelderse MBO'ers volgt een opleiding volgens de meer praktisch georiënteerde beroepsbegeleidende leerweg (BBL). Het percentage BBL-leerlingen is lager dan het percentage BBL-gediplomeerden (zie tabel 2.1). Vooral binnen MBO Dienstverlening en gezondheidszorg is het verschil groot: ongeveer $30 \%$ van de leerlingen volgt een BBL-opleiding, terwijl $45 \%$ van de gediplo-

12. De gegevens over leerlingen zijn afkomstig van het CBS. De jaartallen die genoemd worden bij de aantallen leerlingen hebben betrekking op het eerste jaar van het betreffende schooljaar. Het jaar 2003 duidt derhalve op het schooljaar 2003/2004. 
meerden een BBL-opleiding heeft gevolgd. Voor de techniekopleidingen is het verschil iets kleiner.

Tabel 2.2

Aantal leerlingen in het VMBO en het MBO naar opleidingscategorie en leerweg, Gelderland

\begin{tabular}{lrrr} 
& 1997 & 2003 & $\begin{array}{r}\text { BBL in 2003 } \\
\%\end{array}$ \\
\hline VMBO Theorie & & & - \\
VMBO Natuur en techniek & 52.040 & 56.410 & - \\
VMBO Verzorging & 9.090 & 9.320 & - \\
VMBO Economie & 3.650 & 5.900 & - \\
VMBO Totaal (incl. overig) & 3.770 & 5.930 & - \\
& 68.570 & 77.770 & 51 \\
HAVO/VWO & & & 30 \\
MBO Natuur en techniek & 35.490 & 37.170 & 21 \\
MBO Dienstverlening en gezondheidszorg & 17.760 & 15.890 & 33 \\
MBO Economie & 14.910 & 18.170 & 15.780 \\
MBO Totaal (incl. overig) & 12.460 & 51.230 & \\
& 45.150 & 51.230 & \\
\hline
\end{tabular}

Bron: ROA/CBS

Figuur 2.3

VMBO-leerlingen naar opleidingscategorie, percentage van het totale aantal VMBO-leerlingen (excl. VMBO theorie), Gelderland

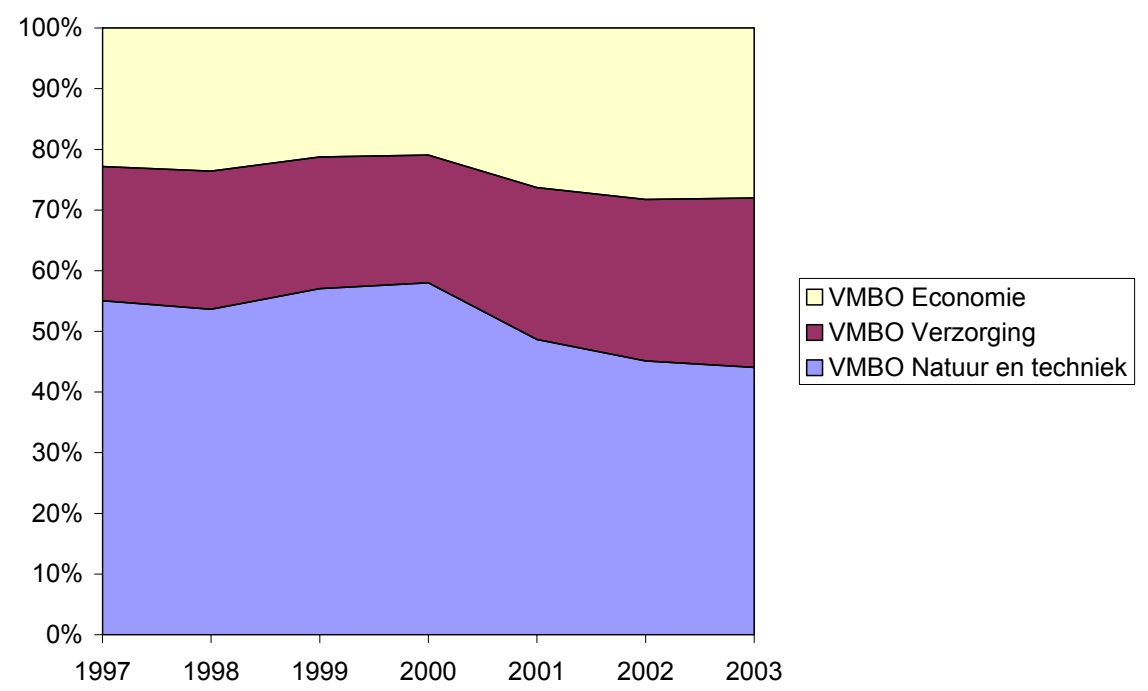

Bron: ROA/CBS

Het kleinere aandeel BBL-leerlingen dan BBL-gediplomeerden kan erop wijzen dat de populariteit van de beroepsbegeleidende leerweg onder leerlingen aan het afnemen is, of dat werkgevers vanwege de tegenvallende conjunctuur minder leerlingenplaatsen creëren. Een hele andere verklaring zou kunnen zijn dat de school- 
uitval bij BBL-opleidingen lager is dan bij BOL-opleidingen. Wellicht is het raadzaam leerlingen meer op de mogelijkheden van het BBL te wijzen, dat gezien het meer praktische en laagdrempelige karakter een belangrijke rol kan vervullen in het streven om meer jongeren een startkwalificatie te laten halen.

Het totale aantal VMBO-leerlingen is in 2003 ruim 9.000 hoger dan in 1997. Het aantal VMBO-leerlingen is voor alle richtingen toegenomen. De toename is het kleinst voor VMBO Natuur en techniek. Figuur 2.3 laat zien dat het aandeel leerlingen $V M B O$ Natuur en techniek in het totaal aantal leerlingen met een voorbereidende beroepsopleiding met ruim 10\%-procentpunten is afgenomen. Het aandeel leerlingen van VMBO Economie en VMBO Verzorging is daarentegen gestegen.

Figuur 2.4 geeft de ontwikkeling van het aandeel leerlingen per opleidingscategorie in het middelbaar beroepsonderwijs weer. Uit de figuur wordt duidelijk toont dat ook in het middelbaar beroepsonderwijs het percentage leerlingen dat een technische opleiding volgt, afneemt ten faveure van het percentage leerlingen bij economie, dienstverlening en gezondheidszorg.

Figuur 2.4

MBO-leerlingen naar opleidingscategorie, percentage van het totale aantal MBO-leerlingen, Gelderland

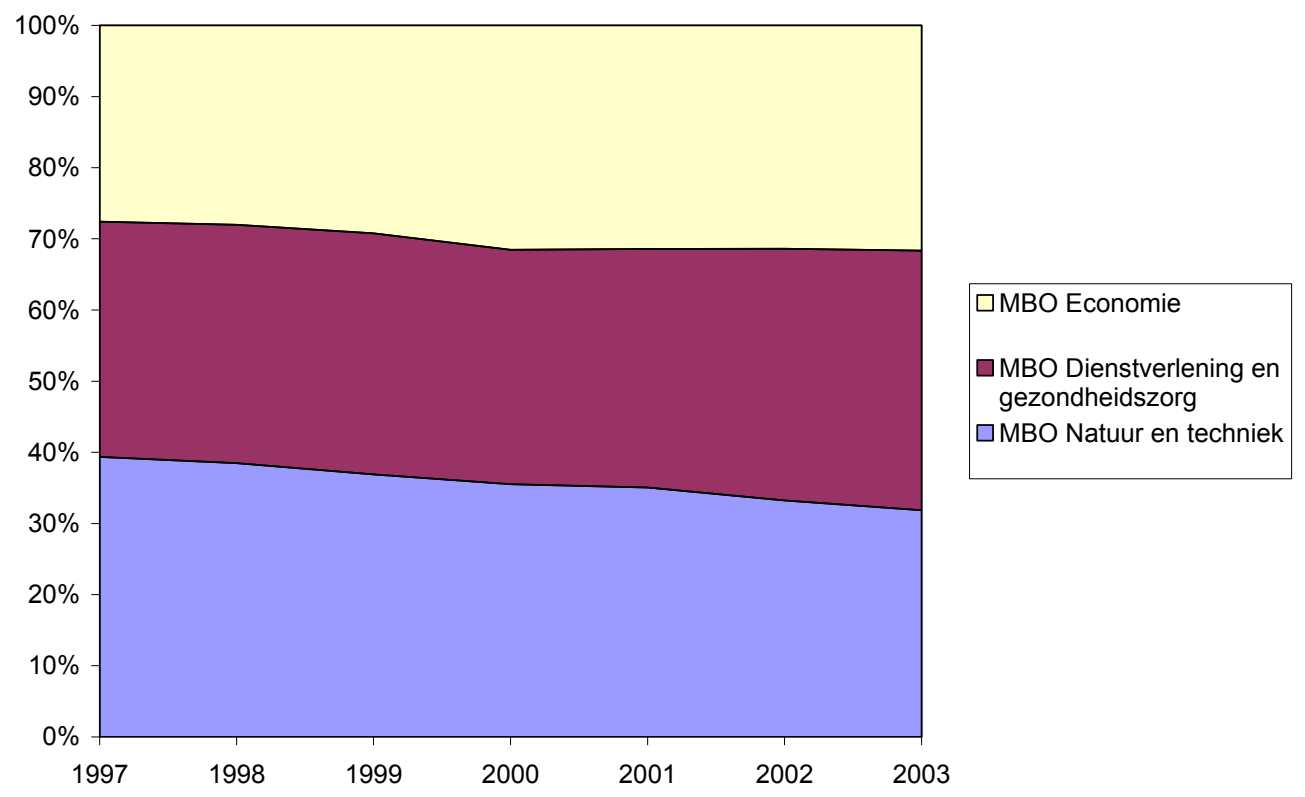

Bron: ROA/CBS

Traditioneel zijn er grote verschillen in de opleidingskeuze van mannen en vrouwen. Uit figuur 2.5 blijkt dat er weinig meisjes kiezen voor VMBO Natuur en techniek en $M B O$ Natuur en techniek, en weinig jongens voor VMBO Verzorging en MBO Dienstverlening en gezondheidszorg. 
Figuur 2.5

Percentage leerlingen naar geslacht per opleidingscategorie, Gelderland, 2003

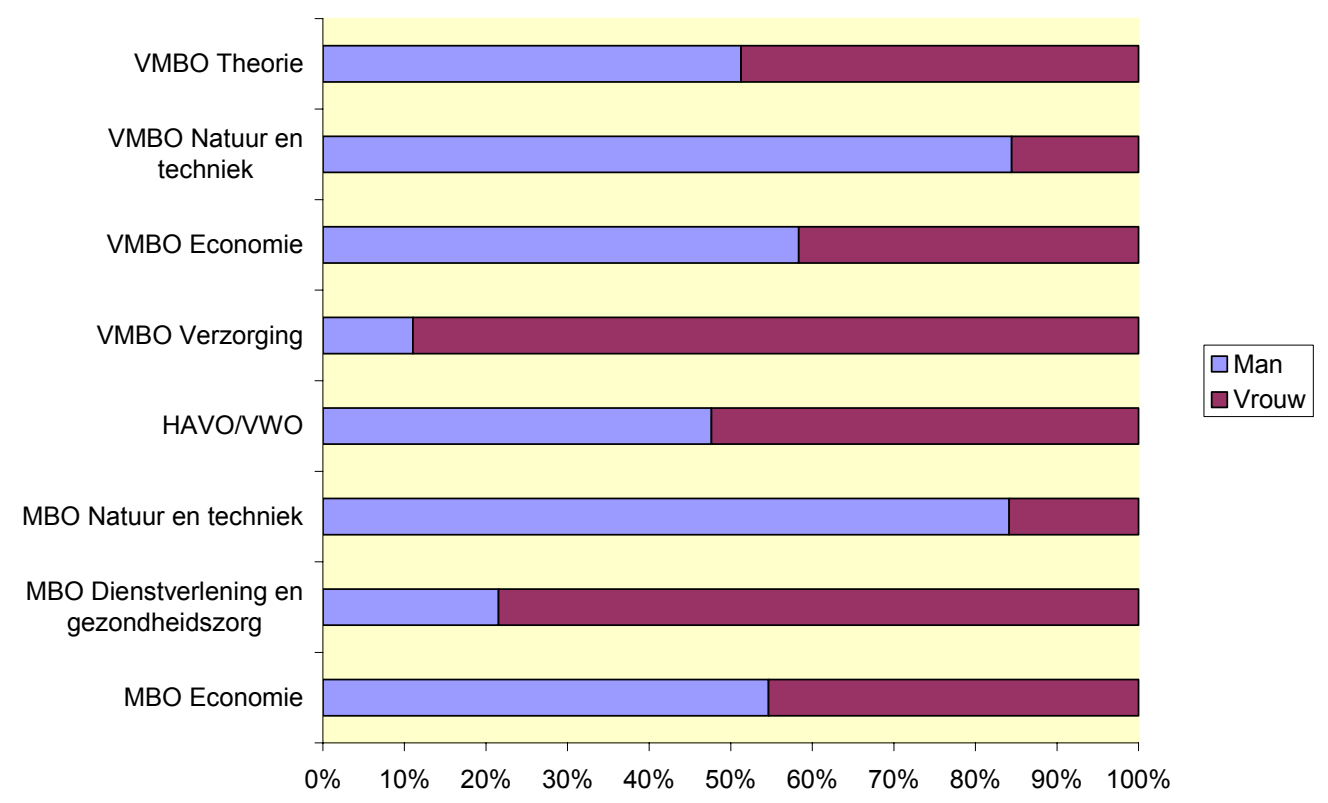

Bron: ROA/CBS

\subsection{Aanbod van schoolverlaters}

In deze paragraaf wordt een overzicht gegeven van de verwachte arbeidsmarktinstroom in Gelderland op de middellange termijn. Het gaat hierbij om het aantal schoolverlaters dat zich over de vijfjaarsperiode van 2003 tot 2008 aanbiedt op de arbeidsmarkt. In deze paragraaf wordt alleen de arbeidsmarktinstroom van de lagere en middelbare opleidingscategorieën besproken, omdat het aanbod van afgestudeerden van het hoger onderwijs niet kan worden toegerekend aan een bepaalde provincie. Hoger opgeleiden zoeken immers veel vaker dan de lager en middelbaar opgeleiden een baan buiten hun regio van afstuderen.

In tabel 2.3 wordt de verwachte arbeidsmarktinstroom van schoolverlaters voor de periode van tot 2008 weergegeven voor de verschillende lagere en middelbare opleidingscategorieën. De arbeidsmarktinstroom van schoolverlaters voor een bepaalde opleidingscategorie is weergegeven als percentage van de werkende beroepsbevolking van de betreffende opleidingscategorie. Voor de meeste lagere en middelbare opleidingscategorieën ligt dit percentage tussen $20 \%$ à $30 \%$, met twee belangrijke uitschieters: VMBO Economie met een veel hoger dan gemiddelde arbeidsmarktinstroom, en MBO Natuur en techniek met een lager dan gemiddelde arbeidsmarktinstroom. De arbeidsmarktinstroom vanuit de verschillende VMBO-opleidingen is voor een belangrijk deel afkomstig van ongeschoolde werkenden die postinitieel alsnog een opleiding op VMBO-niveau hebben afgesloten (ongeveer een derde 
deel)..$^{13}$ De lage arbeidsmarktinstroom voor MBO Natuur en techniek is in overeenstemming met de in de vorige paragraaf geconstateerde achterblijvende belangstelling voor deze richting onder leerlingen van het MBO.

Tabel 2.3

Verwachte arbeidsmarktinstroom van schoolverlaters naar opleidingscategorie voor vijfaarsperiode, als percentage van de werkgelegenheid in 2002, Gelderland en Nederland

\begin{tabular}{lcc} 
Opleidingscategorie & $\begin{array}{c}\text { Gelderland } \\
2003-2008 \\
\%\end{array}$ & $\begin{array}{c}\text { Nederland } \\
2003-2008 \\
\%\end{array}$ \\
\hline Basisonderwijs & 31 & 28 \\
VMBO Theorie & 22 & 23 \\
VMBO Natuur en techniek & 26 & 26 \\
VMBO Economie & 52 & 51 \\
VMBO Verzorging & 29 & 31 \\
HAVO/VWO & 29 & 30 \\
MBO Natuur en techniek & 17 & 17 \\
MBO Economie & 21 & 23 \\
MBO Dienstverlening en gezondheidszorg & 25 & 25 \\
Totaal (incl. HBO en WO) & 23 & 22
\end{tabular}

Bron: ROA

Lagere en middelbare opleidingstypen met de hoogste en laagste arbeidsmarktinstroom van schoolverlaters tot 2008 , op basis van het percentage van het aantal werkenden per opleidingstype in 2002

Hoogste arbeidsmarktinstroom

- VMBO administratie, handel en mode

- VMBO consumptief en levensmiddelentechiek

- VMBO installatietechniek

- VMBO beveiliging

- MBO operationele techniek

- MBO facilitaire dienstverlening

- MBO toerisme en recreatie

- MBO ICT

- MBO sociaal-pedagogisch en welzijn

Laagste arbeidsmarktinstroom

- VMBO grafische techniek

- VMBO fijnmechanische techniek

- MBO procestechniek

13. Door het afronden van één van deze opleidingen ontstaat er aan de vraagzijde vervangingsvraag (zie paragraaf 3.3) naar arbeidskrachten met de 'oude' opleidingsachtergrond, bijv. ongeschoolden die VMBO-diploma hebben gehaald of VMBO'ers die MBO-niveau hebben gehaald. Zie ook hoofdstuk 2 in ROA (2003), De arbeidsmarkt naar opleiding en beroep tot 2008, ROA-R-2003/11, Maastricht. 
De arbeidsmarktinstroom op de middellange termijn levert voor Gelderland en Nederland een vergelijkbaar beeld op. Op MBO-niveau ligt de arbeidsmarktinstroom voor Gelderland over het algemeen even hoog als voor Nederland. Voor de lagere en middelbare opleidingscategorieën is de Gelderse arbeidsmarktinstroom relatief lager voor VMBO Theorie, VMBO Verzorging, HAVO/VWO en MBO Economie. Daarentegen is voor Basisonderwijs en VMBO Economie de arbeidsmarktinstroom van schoolverlaters iets groter dan landelijk. Het is vooral opmerkelijk dat Gelderland een duidelijk groter percentage schoolverlaters zonder enig diploma (Basisonderwijs, veelal 'drop outs' van het VMBO) heeft.

Tot slot worden in het kader de lagere en middelbare opleidingstypen weergegeven met de hoogste en laagste arbeidsmarktinstroom van schoolverlaters in Gelderland op de middellange termijn. ${ }^{14}$ Voor elk opleidingstype is hierbij de arbeidsmarktinstroom van schoolverlaters berekend als percentage van het aantal werkenden met het betreffende opleidingstype in de Gelderse beroepsbevolking in 2002. De opleidingstypen vallen onder één van de 17 opleidingscategorieën zoals die in de tabellen van dit hoofdstuk (en de volgende hoofdstukken) zijn weergegeven. ${ }^{15} \mathrm{Er}$ kunnen zich nog aanzienlijke verschillen voordoen tussen opleidingstypen binnen dezelfde opleidingscategorie. De opleidingstypen met een hoge arbeidsmarktinstroom waren tot recent zeer populair onder leerlingen die voor hun studiekeuze stonden. Deze leerlingen zitten tot 2008 'in de pijplijn van het onderwijs', en zullen vervolgens doorstuderen of instromen op de arbeidsmarkt. Zo blijkt dat bijvoorbeeld MBO ICT en MBO toerisme en recreatie hele populaire opleidingen waren, waardoor er een relatief grote arbeidsmarktinstroom is te verwachten gedurende de komende jaren.

Uit het overzicht blijkt verder dat een aantal MBO-opleidingstypen in de richting techniek de laagste arbeidsmarktinstroom kennen. In hoofdstuk 4 zal duidelijk worden of de over het algemeen lage arbeidsmarktinstroom bij techniek voldoende zal zijn om de verwachte vraag naar arbeidskrachten voor de betreffende opleidingen op te vangen.

14. Zoals gezegd wordt de arbeidsmarktinstroom voor de opleidingstypen op HBO- en WOniveau niet aan regio's toegerekend.

15. Zie Bijlage $B$ voor volledig overzicht van de opleidingstypen binnen één van 17 opleidingscategorieën. Zie verder ook Raming Digitaal voor de exacte percentages per opleidingstype. Zoals eerder opgemerkt wordt de arbeidsmarktinstroom van afgestudeerden van het hoger onderwijs niet weergegeven, omdat deze door de relatief grote mobiliteit van hoger opgeleiden niet of nauwelijks aan regio's toe te rekenen valt. 



\section{De vraag naar arbeidskrachten op de Gelderse arbeidsmarkt}

De sectorale werkgelegenheidsgroei in Gelderland en de verschuivingen in de beroepen- en de opleidingenstructuur binnen sectoren bepalen de uitbreidingsvraag naar beroep en opleiding. De vooruitzichten met betrekking tot de uitbreidingsvraag tot 2008 zijn in Gelderland ten opzichte van Nederland gunstiger voor de Pedagogische beroepen, de Openbare orde- en veiligheidsberoepen en de Culturele beroepen, en ongunstiger voor de Transportberoepen en de Sociaal-culturele beroepen. Verder is er wat betreft de uitbreidingsvraag in Gelderland een tweedeling naar opleidingsniveau zichtbaar, met ongunstige verwachtingen voor de werkgelegenheid van degenen die geen startkwalificatie hebben, dat willen zeggen de ongeschoolden en de lager geschoolden (tot MBO). Vanaf MBO-niveau laten vooral MBO Natuur en techniek en MBO Economie een lagere uitbreidingsvraag zien dan landelijk.

De uitbreidingsvraag draagt voor ongeveer een vijfde deel bij aan het totaal aantal baanopeningen tot 2008, terwijl vier vijfde deel van de baanopeningen door de vervangingsvraag tot stand komt. De vervangingsvraag wordt bepaald door de uitstroom op de arbeidsmarkt ten gevolge van bijvoorbeeld de vergrijzing en de verzorging van jonge kinderen in het gezin, maar ook door de baanmobiliteit tussen beroepen en de doorstroom op de arbeidsmarkt in samenhang met postinitiële scholing. Er is in Gelderland sprake van een hoge vervangingsvraag voor de Openbare orde- en veiligheidsberoepen en de Pedagogische beroepen. Dat komt voor een belangrijke deel door het vergrijsde personeelsbestand in deze beroepsklassen. Omgekeerd valt de lage vervangingsvraag bij de Informaticaberoepen toe te schrijven aan het grote aandeel jongeren dat in deze beroepen werkzaam is. De vervangingsvraag is hoog voor Basisonderwijs, VMBO Theorie en VMBO Natuur en techniek. Met name voor werkenden die geen beroepsopleiding hebben gevolgd, geldt dat zij na verloop van tijd - mede als gevolg van het gebrek aan carrièreperspectief - relatief vaak aan een postinitiële opleiding gaan deelnemen. De vervangingsvraag die ontstaat door deze zogenaamde 'doorleerders' vormt voor Basisonderwijs en VMBO Theorie een belangrijk deel van de totale vervangingsvraag.

Met name de vergrijzing in Gelderland zorgt voor een hogere vervangingsvraag waardoor ook het aantal baanopeningen relatief groot is ten opzichte van Nederland. Voor alle beroepsklassen met uitzondering van de Economisch-administratieve beroepen, de Sociaal-culturele beroepen en de Transportberoepen is het percentage baanopeningen in Gelderland groter dan voor Nederland. Voor deze beroepsklassen is het verschil met Nederland te wijten aan de achterblijvende vervangingsvraag en de afname van de werkgelegenheid, terwijl landelijk nauwelijks sprake is van een dalende werkgelegenheid in deze beroepsklassen. Verder is het opmerkelijk dat de baanopeningen in Gelderland relatief vaak aan de onderkant van de arbeidsmarkt ontstaan. De hoge totale vraag van de opleidingen Basisonderwijs, VMBO Theorie en HAVO/VWO is deels toe te schrijven aan het belang dat 'doorleerders' hebben binnen de vervangingsvraag voor deze opleidingen. Het percentage baanopeningen 
is op MBO-, HBO- en WO-niveau meestal kleiner dan landelijk, met uitzondering van WO Medisch. Voor de lagere opleidingen en HAVO/VWO geldt juist het omgekeerde. Alleen VMBO Verzorging heeft een kleiner percentage baanopeningen dan landelijk.

\subsection{Inleiding}

In dit hoofdstuk wordt nader ingegaan op de verwachte ontwikkelingen aan de vraagzijde van de Gelderse arbeidsmarkt. Daarbij worden de ontwikkelingen in Gelderland en Nederland op de middellange termijn (tot 2008) met elkaar vergeleken. Er kunnen twee componenten van vraag naar schoolverlaters onderscheiden worden, namelijk de uitbreidingsvraag ten gevolge van de verwachte werkgelegenheidsgroei en de vervangingsvraag, veroorzaakt door (tijdelijke) uittrede van reeds werkenden en de baanmobiliteit van werkenden. In paragraaf 3.2 komt eerst de verwachte uitbreidingsvraag aan de orde, waarbij gedifferentieerd wordt naar sector, beroep en opleiding. In paragraaf 3.3 wordt de vervangingsvraag naar beroep en opleiding besproken. In paragraaf 3.4 wordt de verwachte ontwikkeling van het aantal baanopeningen naar beroep en opleiding weergegeven. In elke paragraaf worden tevens de beroepsgroepen en opleidingstypen (uit de verschillende beroepsklassen respectievelijk opleidingscategorieën, zie Bijlage B) met de grootste of kleinste verwachte groei van de vraag naar arbeid weergegeven.

\subsection{Uitbreidingsvraag}

\section{Sector}

In deze paragraaf bespreken we de uitkomsten van de eerste vraagcomponent, de uitbreidingsvraag. Tabel 3.1 geeft voor de verschillende sectoren de uitbreidingsvraag op de middellange termijn weer als percentage van de werkgelegenheid in het basisjaar (2002), waarbij ook een vergelijking wordt gemaakt met de landelijke gegevens. ${ }^{16}$

Tot 2008 groeit de Gelderse werkgelegenheid naar verwachting slechts met $1 \%$. Ook voor Nederland als geheel wordt eenzelfde lage groei van de werkgelegenheid verwacht. De totale werkgelegenheidsgroei is het gemiddelde over alle sectoren. De groeiverwachtingen van de werkgelegenheid in de verschillende sectoren lopen echter aanzienlijk uiteen. Voor Gelderland wordt een krimp van de werkgelegenheid verwacht van $12 \%$ voor Landbouw en visserij en $15 \%$ voor Chemie, en een groei van de werkgelegenheid van $9 \%$ voor Kwartaire diensten en Energie. Andere sectoren met een aanzienlijke afname van de Gelderse werkgelegenheid zijn de industriesectoren Voeding, Metaal en elektrotechniek en Overige industrie, en de dienstensector Transport en communicatie.

16. ROA (2003), De arbeidsmarkt naar opleiding en beroep tot 2008, ROA-R-2003/11, Maastricht. 
De verwachte regionale werkgelegenheidsgroei op de middellange termijn verschilt het meest van de verwachte landelijke groei voor de sectoren Energie en Bank- en verzekeringswezen. De sector Energie heeft in Gelderland gunstigere vooruitzichten dan in Nederland. In mindere mate geldt dit ook voor Handel en reparatie, Kwartaire diensten en Overheid en onderwijs. Omgekeerd geven de sectoren Voeding, Chemie en Transport en communicatie een grotere werkgelegenheidskrimp te zien voor Gelderland vergeleken met landelijk. Voor de sector Bank- en verzekeringswezen wordt in Gelderland ook een krimp verwacht, terwijl voor Nederland als geheel groei wordt verwacht.

Tabel 3.1

Verwachte uitbreidingsvraag naar bedrijfssector voor vijfjaarsperiode, als percentage van de werkgelegenheid in 2002, Gelderland en Nederland

\begin{tabular}{lcc}
\hline & Gelderland & Nederland \\
Bedrijfssector & $2003-2008$ & $\%$ \\
& $\%$ & $\%$ \\
& & -12 \\
\hline & -12 & -1 \\
Landbouw en visserij & -6 & -6 \\
Voeding & -15 & -9 \\
Chemie & -9 & -6 \\
Metaal en elektrotechniek & -6 & 2 \\
Overige industrie & 9 & -3 \\
Energie & -3 & 2 \\
Bouw en onroerend goed & 4 & -5 \\
Handel en reparatie & -9 & 6 \\
Transport en communicatie & -1 & 3 \\
Bank- en verzekeringswezen & 3 & 6 \\
Horeca en zakelijke dienstverlening & 9 & 5 \\
Kwartaire diensten & 7 & \\
Overheid en onderwijs & & 1 \\
Totaal & 1 & \\
& & \\
\hline
\end{tabular}

Bron: BEO/CPB/ROA

\section{Beroep}

De verwachte groei of krimp van de werkgelegenheid naar bedrijfssector heeft gevolgen voor uitbreidingsvraag naar beroep. Daarbij speelt de beroepensamenstelling van sectoren een belangrijke rol, en de verwachte verschuiving van de beroepenstructuur binnen sectoren. In tabel 3.2 is de uitbreidingsvraag naar beroepsklasse weergegeven. Op de middellange termijn vertonen drie beroepsklassen in Gelderland een grote uitbreidingsvraag, namelijk de Informaticaberoepen, de Pedagogische beroepen en de Culturele beroepen. De verwachte uitbreidingsvraag over de gehele prognoseperiode voor deze beroepsklassen is meer dan $10 \%$ van het aantal werkenden per beroepsklasse in $2002 .^{17}$ Deze beroepsklassen zijn daarmee verantwoordelijk voor bijna de helft van de uitbreidingsvraag op de middellange termijn. Met name de relatief grote uitbreidingsvraag voor de Informaticaberoepen is opmerkelijk

17. Dit komt overeen met ongeveer 9.800 arbeidsplaatsen. 
aangezien de Provinciale Werkgelegenheidsenquête (PWE) Gelderland ${ }^{18}$ laat zien deze beroepsklasse tot recent te maken had met een aanzienlijk banenverlies. De komende jaren moeten uitwijzen of er inderdaad een herstel van de werkgelegenheid in de Informaticaberoepen zal plaatsvinden.

Negatieve uitschieters wat betreft de uitbreidingsvraag in Gelderland zijn de Agrarische beroepen, de Technische en industrieberoepen en de Transportberoepen. Dit is in overeenstemming met de verwachte werkgelegenheidsontwikkeling in de bedrijfssectoren waar deze beroepen relatief veel in voorkomen (zie tabel 3.1). Zo zullen de Agrarische beroepen terug te vinden zijn in de sector Landbouw en visserij, waar een werkgelegenheidsdaling van $12 \%$ verwacht wordt voor de periode tot 2008 . Volgens de PWE Gelderland wordt de afname van de industriële werkgelegenheid onder andere veroorzaakt door de verslechterde concurrentiepositie en het verplaatsen van productiecapaciteit naar lagelonenlanden. ${ }^{19}$

Tabel 3.2

Verwachte uitbreidingsvraag naar beroepsklasse voor vijfjaarsperiode, als percentage van de werkgelegenheid in 2002, Gelderland en Nederland

\begin{tabular}{lcc}
\hline & Gelderland & Nederland \\
Beroepsklasse & $2003-2008$ & $\begin{array}{c}2003 \\
\%\end{array}$ \\
& $\%$ & 5 \\
& & 5 \\
Pedagogische beroepen & 10 & -9 \\
Culturele beroepen & 9 & -3 \\
Agrarische beroepen & -8 & -0 \\
Technische en industrieberoepen & -3 & 3 \\
Transportberoepen & -3 & 1 \\
Medische en paramedische beroepen & 5 & 11 \\
Economisch-administratieve beroepen & -0 & 4 \\
Informaticaberoepen & 11 & 3 \\
Sociaal-culturele beroepen & -1 & 2 \\
Verzorgende en dienstverlenende beroepen & 6 & 1 \\
Openbare orde- en veiligheidsberoepen & 7 & \\
Totaal & & \\
\end{tabular}

Bron: ROA

Opvallend is dat de grote negatieve uitbreidingsvraag in de industriële bedrijfssectoren (Voeding, Chemie, Overige industrie) zich vertalen in een relatief geringe negatieve uitbreidingsvraag voor de Technische en industrieberoepen van $-3 \%$. Dit kan worden verklaard door twee factoren. Ten eerste, een relatief grote uitbreidingsvraag in de sector Energie, waarin ook veel Technische en industrieberoepen voorkomen. Ten tweede, de mogelijkheid dat de krimp in de industriële bedrijfssectoren veroorzaakt wordt door de afname van de werkgelegenheid in niettechnische en niet-industrieberoepen. Vooral ook in het licht van 'outsourcing', i.e.

18. PWE, (2003), Eerste uitkomsten werkgelegenheidsonderzoek Gelderland 2003, provincie Gelderland, Arnhem.

19. BEO (2003), Industrie en logistieke dienstverlening; plaats en betekenis binnen de Gelderse economie, provincie Gelderland, Arnhem. 
het afstoten van werkzaamheden van dienstverlenende aard door industriële bedrijven, kan deze factor van belang zijn.

Figuur 3.2 laat zien dat de uitbreidingsvraag op de middellange termijn voor Gelderland ten opzichte van Nederland vooral gunstiger is voor de Pedagogische beroepen, de Culturele beroepen, en de Openbare orde- en veiligheidsberoepen. De uitbreidingsvraag is relatief laag voor de Sociaal-culturele beroepen en de Transportberoepen.

Beroepsgroepen met de hoogste en laagste uitbreidingsvraag tot 2008 , op basis van het percentage van het aantal werkenden per beroepsgroep in 2002

Hoogste uitbreidingsvraag

- Onderwijskundigen en pedagogen

- Sportinstructeurs

- Bibliothecarissen

- Grafisch ontwerpers

- Laboratorium-assistenten

- Laboranten

- Technisch analisten

- Weg- en waterbouwkundigen

- Medisch analisten

- Productieplanners

- Informatici

- Hulpkrachten horeca en verzorging

- Aspirant politieagenten, soldaten en beveiligingshulpkrachten

Laagste uitbreidingsvraag

- Productiemedewerkers

- Monteurs

- Werktuigbouwkundig ontwerpers en hoofden technische dienst

- Elektrotechnisch ontwerpers en bedrijfshoofden

- Grafische vakkrachten

- Procestechnologen

- Schippers en conducteurs

- Technisch-bedrijfskundig medewerkers

- Technisch systeemanalisten

- Activiteitenbegeleiders en medewerkers arbeidsbemiddeling

- Winkeliers

- Café- en snackbarhouders

- Brandweerlieden

Elke beroepsklasse bestaat uit meerdere beroepsgroepen (zie Bijlage B). De vooruitzichten voor een beroepsklasse hoeven dus niet noodzakelijkerwijs te gelden voor alle onderliggende beroepsgroepen. In het kader worden de beroepsgroepen 
weergegeven met de grootste respectievelijk de kleinste uitbreidingsvraag tot $2008{ }^{20}$ De beroepsgroep productieplanners, die valt onder de Technische en industrieberoepen, is één van de beroepsgroepen met de hoogste uitbreidingsvraag. Verder valt op de hoge uitbreidingsvraag voor vier medisch-technische beroepsgroepen die geassocieerd kunnen worden met laboratoriumwerkzaamheden, te weten laboratorium-assistenten, laboranten, technisch analisten en medisch analisten. De negatieve uitbreidingsvraag van $-3 \%$ voor de Technische en industrieberoepen wordt met name veroorzaakt door de zeven genoemde onderliggende technische beroepsgroepen met de laagste (en negatieve) uitbreidingsvraag, waaronder de relatief grote beroepsgroepen productiemedewerkers en monteurs.

\section{Opleiding}

De vraag naar werknemers die in een bepaald beroep ingezet kunnen worden, kan ook worden voorgesteld als een vraag naar mensen met een bepaalde opleidingsachtergrond. Indien er een vacature is voor een apothekersassistent wordt namelijk tevens een indicatie verkregen van de vereiste opleiding om dit beroep te kunnen (en mogen) uitvoeren. Voor een apothekersassistent geldt dat ze in het bezit moet zijn van een diploma MBO apothekersassistent. Zo kan de vraag naar een apothekersassistent ook vertaald worden naar de vraag naar iemand met een diploma $M B O$ apothekersassistent. Met name in de zorg en het onderwijs is een duidelijk relatie zichtbaar tussen het beroep en de opleiding. Voor de meeste andere sectoren geldt dat personen die hetzelfde beroep uitoefenen een heel verschillende opleidingsachtergrond kunnen hebben. Van belang is verder dat de door werkgevers gevraagde opleidingsachtergrond voor beroepen ook aan veranderingen onderhevig is. Dit geldt zowel voor het gevraagde opleidingsniveau ('upgrading') als de gevraagde opleidingsrichting. Dit laatste sluit bijvoorbeeld aan bij de tendens dat er steeds meer schoolverlaters buiten hun eigen beroependomein terecht komen.

Tabel 3.3 geeft een overzicht van de verwachte uitbreidingsvraag naar opleidingscategorie voor Gelderland en Nederland. Uit deze tabel komt naar voren dat met name de uitbreidingsvraag op lagere en middelbaar niveau negatief is, terwijl de meeste richtingen op hoger niveau een positieve uitbreidingsvraag laten zien. Er blijkt dus een tweedeling op de arbeidsmarkt te bestaan met gunstige verwachtingen voor de werkgelegenheidsgroei bij de hogere opleidingen. Zo is de uitbreidingsvraag voor $\mathrm{HBO}$ en WO naar verwachting $5 \%$ over de vijfjaarsperiode van 2003 tot $2008 .^{21}$ Alleen $H B O$ Natuur en techniek kent een negatieve uitbreidingsvraag. De uitbreidingsvraag voor MBO Dienstverlening en gezondheidszorg bedraagt ook $5 \%{ }^{22}$ en is daarmee verantwoordelijk voor de grootste vraag naar nieuwe arbeidsplaatsen op MBO-niveau.

20. Voor het complete overzicht van de middellangetermijnprognoses voor de 127 onderscheiden beroepsgroepen wordt verwezen naar het bijbehorende digitale arbeidsmarktinformatiesysteem RAMING Digitaal.

21. Dit komt overeen met 11.900 personen voor alle HBO- en WO-opleidingscategorieën tezamen.

22. Dit komt overeen met 4.100 personen. 
Tabel 3.3

Verwachte uitbreidingsvraag naar opleidingscategorie voor vijfjaarsperiode, als percentage van de werkgelegenheid in 2002, Gelderland en Nederland

\begin{tabular}{lcc}
\hline Opleidingscategorie & $\begin{array}{c}\text { Gelderland } \\
2003-2008\end{array}$ & $\begin{array}{c}\text { Nederland } \\
2003-2008 \\
\%\end{array}$ \\
& $\%$ & \\
& & -24 \\
Basisonderwijs & -24 & -1 \\
VMBO Theorie & 2 & -15 \\
VMBO Natuur en techniek & -14 & -0 \\
VMBO Economie & 3 & -7 \\
VMBO Verzorging & -0 & 9 \\
HAVO/VWO & 10 & 6 \\
MBO Natuur en techniek & -1 & -0 \\
MBO Economie & -2 & 5 \\
MBO Dienstverlening en gezondheidszorg & 5 & 5 \\
HBO Natuur en techniek & -2 & 5 \\
HBO Economie & 1 & 6 \\
HBO Onderwijs en sociaal-cultureel & 8 & 18 \\
HBO Paramedisch & 15 & 4 \\
WO Natuur en techniek & 4 & 11 \\
WO Economie & 10 & 9 \\
WO Letteren en sociaal-cultureel & 6 & 1 \\
WO Medisch & 5 & 1 \\
Totaal & 1 & \\
& &
\end{tabular}

Bron: ROA

Opleidingstypen met de hoogste en laagste uitbreidingsvraag tot 2008 , op basis van het percentage van het aantal werkenden per opleidingstype in 2002

Hoogste uitbreidingsvraag

- VMBO beveiliging

- MBO apothekersassistent

- MBO gezondheidstechniek

- MBO horeca

- HBO (fysio)therapie

- HBO bibliotheek en documentatie

- WO bouwkunde

-WO informatica en bestuurlijke informatiekunde

- WO econom(etr)ie

- WO kunstwetenschappen

Laagste uitbreidingsvraag

- Basisonderwijs

- VMBO landbouw en natuurlijke omgeving

- VMBO installatietechniek

- VMBO mechanische techniek

- VMBO fijnmechanische techniek

- VMBO voertuigentechniek

- VMBO grafische techniek

- VMBO brood en banket

- VMBO consumptief en levensmiddelentechniek

- MBO brood en banket 
Over het algemeen geldt dat de verwachtingen voor de uitbreidingsvraag op de middellange termijn in Gelderland het landelijke beeld volgen. Maar ook nu zijn er verschillen. ${ }^{23}$ Zo is er een negatieve uitbreidingsvraag voor MBO Natuur en techniek en $H B O$ Natuur en techniek in Gelderland, terwijl er in Nederland sprake is van uitbreidingsvraag van $6 \%$ respectievelijk $5 \%$. Opleidingscategorieën waarvoor in Nederland een krimp in de werkgelegenheid wordt verwacht terwijl voor Gelderland met een werkgelegenheidsgroei rekening moet worden gehouden, zijn VMBO Theorie en VMBO Economie. Opvallend is verder dat de uitbreidingsvraag voor WO Medisch wat groter is dan landelijk, terwijl voor HBO Paramedisch de uitbreidingsvraag juist wat kleiner is.

In het kader staan opleidingstypen vermeld met de hoogste en laagste uitbreidingsvraag voor de middellange termijn. Deze opleidingstypen vallen onder één van de opleidingscategorieën van tabel 3.3. Een lage (en negatieve) uitbreidingsvraag komt met name voor bij technische opleidingstypen op VMBO-niveau. Zo is de lage uitbreidingsvraag voor VMBO Natuur en techniek toe te schrijven aan de onderliggende opleidingstypen VMBO landbouw en natuurlijke omgeving en VMBO mechanische techniek. Opvallend is verder dat VMBO beveiliging behoort tot de opleidingstypen met de hoogste uitbreidingsvraag, evenals WO kunstwetenschappen.

\subsection{Vervangingsvraag}

In deze paragraaf behandelen we de tweede vraagcomponent: de vervangingsvraag. De vervangingsvraag is de vraag naar arbeidskrachten welke voortvloeit uit het vertrek van werkenden. Deze werkenden kunnen om een breed scala aan redenen besluiten al dan niet tijdelijk de arbeidsmarkt te verlaten. Hierbij kan gedacht worden aan pensioen, VUT, arbeidsongeschiktheid, zorgtaken etc. Een andere oorzaak van vervangingsvraag is de baanmobiliteit van werkenden. Voor zover werkenden dan veranderen van beroepsgroep of van opleidingsachtergrond door het volgen van cursussen of opleidingstrajecten, ontstaat er vervangingsvraag voor het beroep van waaruit men de overstap maakt of voor de 'oude' opleidingsachtergrond. Tenzij er sprake is van een reductie van het aantal arbeidsplaatsen geldt dat een werkgever de vertrekkende werknemers zal moeten vervangen.

\section{Beroep}

Tabel 3.4 geeft een overzicht van de verwachte vervangingsvraag per beroepsklasse voor Gelderland op de middellange termijn. De vervangingsvraag in Gelderland is gelijk aan bijna 130.000 arbeidsplaatsen voor de vijfjaarsperiode van 2003 tot 2008 . Dit aantal is equivalent aan $16 \%$ van het aantal werkenden in het basisjaar (2002).

Gezien de oorzaken van arbeidsmarktuittrede is het duidelijk dat de vervangingsvraag voor een belangrijk deel wordt bepaald door de samenstelling van het perso-

23. Deze verschillen zijn niet eenvoudig te verklaren. Hiervoor zou nader onderzoek verricht moeten worden. 
neelsbestand in de verschillende beroepsklassen. ${ }^{24}$ De leeftijd- en geslachtsopbouw van de werkenden binnen de beroepsklassen zijn voor een belangrijk deel verantwoordelijk voor de verwachte uittrede van de arbeidsmarkt. Wanneer een beroepsklasse getypeerd wordt door een groot aandeel ouderen op VUT- en pensioengerechtigde leeftijd, ligt het in de lijn der verwachting dat deze beroepsklasse binnenkort veel vervangingsvraag tegemoet kan zien.

Tabel 3.4

Verwachte vervangingsvraag naar beroepsklasse voor vijfjaarsperiode, als percentage van de werkgelegenheid in 2002, Gelderland en Nederland

\begin{tabular}{lcc}
\hline & Gelderland & Nederland \\
Beroepsklasse & $2003-2008$ & $\%$ \\
& $\%$ & $\%$ \\
& & 22 \\
& & 18 \\
Pedagogische beroepen & 21 & 18 \\
Culturele beroepen & 18 & 17 \\
Agrarische beroepen & 18 & 15 \\
Technische en industrieberoepen & 18 & 18 \\
Transportberoepen & 13 & 16 \\
Medische en paramedische beroepen & 17 & 9 \\
Economisch-administratieve beroepen & 14 & 17 \\
Informaticaberoepen & 9 & 16 \\
Sociaal-culturele beroepen & 15 & 16 \\
Verzorgende en dienstverlenende beroepen & 15 & 16 \\
Openbare orde- en veiligheidsberoepen & 25 & \\
& & 16 \\
Totaal & & \\
\end{tabular}

Bron: ROA

De vervangingsvraag is over de tijd genomen meestal vrij stabiel. Door de geleidelijke ontwikkelingen in de demografie is de vervangingsvraag niet zo afhankelijk van de conjunctuur als de uitbreidingsvraag. Op de middellange termijn is er in Gelderland sprake van een hoge vervangingsvraag voor de Pedagogische beroepen en de Openbare orde- en veiligheidsberoepen. Deze beroepsklassen kunnen, zowel landelijk als regionaal, worden getypeerd als beroepsklassen met veel oudere mannen onder het personeel. Voor mensen werkzaam in met name de laatste beroepsklasse kan ook het functioneel leeftijdsontslag (FLO) een rol spelen. Zo worden beroepsbrandweermannen vaak in een FLO-functie ingedeeld waardoor de leeftijd waarop ze met pensioen gaan daalt. ${ }^{25}$ Omgekeerd valt de lage vervangingsvraag bij de Informaticaberoepen toe te schrijven aan het relatief jonge personeelsbestand. De vervangingsvraag in de Openbare orde- en veiligheidsberoepen is voor Gelderland aanzienlijk groter dan voor Nederland.

24. Zie voor een beschouwing over de samenhang tussen de vervangingsvraag en de opbouw van het personeelsbestand ook hoofdstuk 2 van ROA (2003), De arbeidsmarkt naar opleiding en beroep tot 2008, ROA-R-2003/11, Maastricht.

25. Zie www.car-uwo.nl voor meer informatie over FLO-functies. 
Beroepsgroepen met de hoogste en laagste vervangingsvraag tot 2008 , op basis van het percentage van het aantal werkenden per beroepsgroep in 2002

Hoogste vervangingsvraag

-Docenten exacte, medische en verzorgende vakken (2e en 3 e gr.)

-Docenten exacte, medische en verzorgende vakken (1e gr. en WO)

-Docenten landbouw en techniek (2e en 3e gr.)

-Docenten economisch-administratieve vakken (2e en $3 \mathrm{e}$ gr.)

-Docenten sociale vakken (1e gr. en WO)

-Docenten 2e en $3 e$ graads zonder specialisatie

- Geestelijk verzorgers

- Geestelijken

-Conciërges

-Vliegers, scheepskapiteins en leidinggevenden transport

-Politieagenten, onderofficieren en beveiligingsemployés

-Politie-inspecteurs en officieren

Laagste vervangingsvraag

- Zweminstructeurs

- Grafisch ontwerpers

-Agrarische hulparbeiders

- Stewards

-Boekhouders en secretaresses

- Commercieel medewerkers

-Programmeurs

-Systeemanalisten

-Informatici

-Activiteitenbegeleiders en medewerkers arbeidsbemiddeling

-Vakkenvullers

-Ziekenverzorgenden

-Brandweerlieden

In het kader staan de verwachtingen voor de vervangingsvraag op het lagere aggregatieniveau weergegeven. Een lage vervangingsvraag is terug te vinden bij Informaticaberoepen zoals Informatici, systeemanalisten en programmeurs, en een relatief hoge vervangingsvraag bij veel docentenberoepen binnen de Pedagogische beroepen, geestelijk verzorgers en geestelijken binnen de Culturele beroepen en politie-, leger- en beveiligingspersoneel binnen de Openbare orde- en beveiligingsberoepen.

\section{Opleiding}

De vraag naar arbeidskrachten die in een bepaald beroep kunnen worden ingezet kan ook worden voorgesteld als een vraag naar arbeidskrachten met een bepaalde opleidingsachtergrond. Tabel 3.5 geeft een overzicht van de verwachte vervangingsvraag naar opleidingscategorie voor Gelderland en Nederland. De totale vervangingsvraag is voor opleidingen hoger dan voor beroepen. Dit is het gevolg van het feit dat bij de vervangingsvraag naar opleiding impliciet rekening wordt gehouden met de effecten van doorleergedrag. Dat wil zeggen dat de vervangingsvraag naar 
opleiding wordt vergroot doordat werkenden door het volgen van een hogere of andere postinitiële vervolgopleiding (de zogenaamde 'doorleerders') een andere opleidingsachtergrond krijgen. Dit genereert in feite de uitstroom van werkenden met de oorspronkelijke opleidingsachtergrond, en leidt tot vervangingsvraag indien deze uitstroom daadwerkelijk vervangen moet worden.

Tabel 3.5

Verwachte vervangingsvraag naar opleidingscategorie voor vijfjaarsperiode, als percentage van de werkgelegenheid in 2002, Gelderland en Nederland

\begin{tabular}{lcc}
\hline Opleidingscategorie & $\begin{array}{c}\text { Gelderland } \\
2003-2008 \\
\%\end{array}$ & $\begin{array}{c}\text { Nederland } \\
2003-2008 \\
\%\end{array}$ \\
& \multicolumn{1}{l}{$\begin{array}{c}\text { \% } \\
\text { Basisonderwijs }\end{array}$} & 24 \\
VMBO Theorie & 27 & 21 \\
VMBO Natuur en techniek & 26 & 19 \\
VMBO Economie & 27 & 22 \\
VMBO Verzorging & 25 & 24 \\
HAVO/VWO & 22 & 15 \\
MBO Natuur en techniek & 16 & 19 \\
MBO Economie & 19 & 21 \\
MBO Dienstverlening en gezondheidszorg & 20 & 19 \\
HBO Natuur en techniek & 17 & 18 \\
HBO Economie & 17 & 13 \\
HBO Onderwijs en sociaal-cultureel & 14 & 22 \\
HBO Paramedisch & 19 & 17 \\
WO Natuur en techniek & 13 & 18 \\
WO Economie & 13 & 20 \\
WO Letteren en sociaal-cultureel & 13 & 19 \\
WO Medisch & 20 & 19 \\
Totaal & 20 & \\
& & \\
\hline
\end{tabular}

Bron: ROA

De totale vervangingsvraag voor de middellange termijn komt uit op $20 \%{ }^{26}$ De vervangingsvraag is relatief hoog voor Basisonderwijs, VMBO Theorie, VMBO Natuur en techniek en VMBO Economie, en relatief laag voor veel opleidingscategorieën op HBO- en WO-niveau. Mede als gevolg van het gebrek aan carrièreperspectief zullen veel werkenden met Basisonderwijs als hoogst voltooide opleidingsachtergrond op den duur aan een postinitiële opleiding deelnemen. De vervangingsvraag die ten gevolge van deze 'doorleerders' ontstaat vormt dus een belangrijk deel van de totale vervangingsvraag. Aan de andere kant komt het met name onder laaggeschoolden veel voor dat men de arbeidsmarkt de rug toekeert als de mogelijkheden om door te stromen op de arbeidsmarkt niet gebruikt worden. ${ }^{27}$ Arbeidsongeschiktheid, maar ook de keuze voor het verrichten van huishoudelijke werkzaamheden en zorgtaken binnen het gezin zijn belangrijke redenen om te stappen met

26. Dit komt overeen met ongeveer 163.000 personen voor de vijfjaarsperiode 2003-2008.

27. Zie ook hoofdstuk 5 in ROA (2003), De arbeidsmarkt naar opleiding en beroep tot 2008, ROA-R-2003/11, Maastricht. 
werken. ${ }^{28}$ Ook hierdoor kan vervangingsvraag aan de onderkant van de arbeidsmarkt ontstaan.

Opleidingstypen met de hoogste en laagste vervangingsvraag tot 2008 , op basis van het percentage van het aantal werkenden per opleidingstype in 2002

Hoogste vervangingsvraag

- VMBO bouwtechniek

- VMBO mechanische techniek

- VMBO voertuigentechniek

- VMBO elektrotechniek

- VMBO grafische techniek

- VMBO brood en banket

- VMBO consumptief en levensmiddelentechniek

- HBO lerarenopleiding economie en maatschappij

- HBO lerarenopleiding expressie

- HBO openbare orde en veiligheid

Laagste vervangingsvraag

- MBO procestechniek

- HBO landbouw en veeteelt

- HBO voeding

- HBO toerisme en recreatie

- WO civiele techniek

- WO werktuigbouwkunde

- WO informatica en bestuurlijke informatiekunde

- WO farmacie en medische biologie

- WO bedrijfskunde

- WO kunstwetenschappen

Over het algemeen vertoont Gelderland een iets hogere vervangingsvraag dan landelijk, mede als gevolg van de relatief iets oudere beroepsbevolking. In hoofdstuk 1 kwam al naar voren dat de uitstroom van ouderen in Gelderland groter is vergeleken met de rest van Nederland. In het kader wordt een aantal opleidingstypen met de hoogste en de laagste vervangingsvraag in Gelderland weergegeven. De hoge vervangingvraag bij VMBO Natuur en techniek wordt met name veroorzaakt door de in het kader genoemde onderliggende technische opleidingen. Verder zijn er veel ouderen werkzaam in het onderwijs met als achtergrond economie en maatschappij of expressie. De lage vervangingsvraag voor de opleidingtypen die genoemd worden kan voor een belangrijk deel worden verklaard door het kleine aandeel ouderen.

28. Zie ook hoofdstuk 6 in ROA (2003), De Gelderse arbeidsmarkt 2001-2006, ROA-R2003/4, Maastricht. 


\subsection{Baanopeningen}

Wanneer we de uitbreidingsvraag en de vervangingsvraag optellen geeft dit een indicatie van de totale verwachte vraag: de baanopeningen voor nieuwkomers op de Gelderse arbeidsmarkt. Bij een krimpende werkgelegenheid bestaan de baanopeningen alleen uit de vervangingsvraag. Een krimp van de werkgelegenheid wordt verdisconteerd in de vervangingsvraag. ${ }^{29}$ Voor zover het vertrek van werkenden leidt tot vervanging door nieuwkomers, draagt dat bij aan het aantal baanopeningen.

\section{Beroep}

Tabel 3.6 geeft een overzicht van het totaal aantal baanopeningen als percentage van de werkgelegenheid in het basisjaar (2002) voor de verschillende beroepsklassen in Gelderland en Nederland. Het totaal aan uitbreidingsvraag en vervangingsvraag leidt tot veel baanopeningen bij de Openbare orde- en veiligheidsberoepen, de Pedagogische beroepen en de Culturele beroepen. De verklaring hiervoor ligt mede in de eerder geconstateerde stijging in de werkgelegenheid voor de bedrijfssectoren Kwartaire diensten en Overheid en onderwijs, maar ook in het vergrijsde personeelsbestand in deze beroepen. Een relatief laag aantal baanopeningen wordt verwacht voor de Transportberoepen en Economisch-administratieve beroepen. Ook duidelijk benedengemiddeld is de totale vraag bij de Agrarische beroepen en de Sociaalculturele beroepen. Vooral de afname van de werkgelegenheid in deze beroepsklassen is hier debet aan.

Tabel 3.6

Verwachte baanopeningen naar beroepsklasse voor vijfjaarsperiode, als percentage van de werkgelegenheid in 2002, Gelderland en Nederland

\begin{tabular}{lcc}
\hline Beroepsklasse & Gelderland & Nederland \\
& $2003-2008$ & $\%$ \\
$\%$ & $\%$ \\
& & \\
& & 27 \\
Pedagogische beroepen & 32 & 24 \\
Culturele beroepen & 28 & 18 \\
Agrarische beroepen & 18 & 18 \\
Technische en industrieberoepen & 20 & 17 \\
Transportberoepen & 15 & 21 \\
Medische en paramedische beroepen & 23 & 19 \\
Economisch-administratieve beroepen & 16 & 20 \\
Informaticaberoepen & 21 & 21 \\
Sociaal-culturele beroepen & 18 & 21 \\
Verzorgende en dienstverlenende beroepen & 23 & 20 \\
Openbare orde- en veiligheidsberoepen & 34 & 19 \\
Totaal & & 20 \\
\end{tabular}

Bron: ROA

29. Zie ook F. Cörvers et al. (2004), Methodiek arbeidsmarktprognoses en -indicatoren 20032008, ROA-W-2004/2, Maastricht. Voor elke beroepsgroep en elk opleidingstype geldt dat het totaal aantal baanopeningen gelijk is aan de som van de positieve uitbreidingsvraag en de vervangingsvraag. Vervolgens wordt geaggregeerd naar de 11 beroepsklassen respectievelijk de 17 opleidingscategorieën. 
Voor sommige beroepsklassen vormt de uitbreidingsvraag de voornaamste component van de vraag naar nieuwe arbeidskrachten, voor andere beroepsklassen is juist de vervangingsvraag van groot belang. Figuur 3.1 geeft per beroepsklasse in Gelderland het aandeel van uitbreidingsvraag en vervangingsvraag in de baanopeningen weer.

Figuur 3.1

Aandeel vervangingsvraag in totale vraag per beroepsklasse, 2003-2008, Gelderland

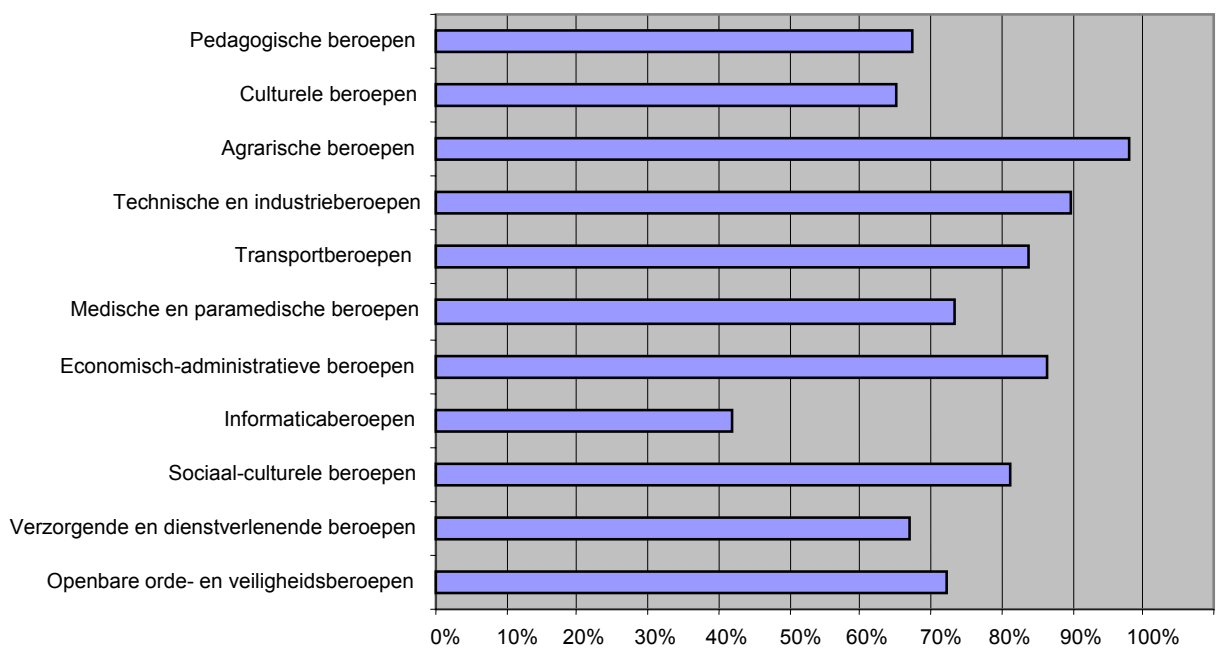

Bron: ROA

Gemiddeld genomen over de verschillende beroepsklassen is de vervangingsvraag met een aandeel van $80 \%$ de belangrijkste component van de vraag naar nieuwe arbeidskrachten. Voor de Agrarische beroepen, Technische en industrieberoepen en de Economisch-administratieve beroepen bedraagt de vervangingsvraag meer dan $85 \%$ van het totaal aantal baanopeningen. Alleen voor de Informaticaberoepen en de Culturele beroepen is de uitbreidingsvraag het belangrijkst.

Naar verwachting zal de totale vraag naar arbeidskrachten als percentage van de werkgelegenheid iets groter zijn voor Gelderland dan voor Nederland als geheel, namelijk $20 \%$ tegenover $19 \%$. Met name de vergrijzing in Gelderland zorgt voor een hogere vervangingsvraag waardoor ook het aantal baanopeningen relatief groot is ten opzichte van Nederland. Voor alle beroepsklassen met uitzondering van de Economisch-administratieve beroepen, de Sociaal-culturele beroepen en de Transportberoepen is het percentage baanopeningen in Gelderland groter dan voor Nederland. Voor deze beroepsklassen is het verschil met Nederland te wijten aan de achterblijvende vervangingsvraag en de dalende van de werkgelegenheid, terwijl landelijk nauwelijks sprake is van een afname van de werkgelegenheid in deze beroepsklassen. 
In het kader staan de beroepsgroepen met de relatief hoogste en laagste percentages baanopeningen voor Gelderland op de middellange termijn. Voor docenten landbouw en techniek ( $2^{e}$ en $3^{e}$ graads) en docenten exacte, medische en verzorgende vakken $\left(2^{e}\right.$ en $3^{e}$ graads) zijn de baanopeningen $51 \%$ respectievelijk bijna $40 \%$ van de werkgelegenheid in 2002. Ook voor veel andere docentenberoepen is het percentage baanopeningen erg hoog, vooral vanwege de erg hoge vervangingsvraag. Opvallend is verder het grote aantal economisch-administratieve beroepsgroepen met een erg laag percentage baanopeningen.

Beroepsgroepen met de meeste en minste baanopeningen tot 2008 , op basis van het percentage van het aantal werkenden per beroepsgroep in 2002

Meeste baanopeningen

- Docenten exacte, medische en verzorgende vakken $\left(2^{\mathrm{e}}\right.$ en $3^{\mathrm{e}} \mathrm{gr}$.)

- Docenten landbouw en techniek ( $2^{\mathrm{e}}$ en $3^{\mathrm{e}}$ gr.)

- Docenten economisch-administratieve vakken $\left(2^{\mathrm{e}}\right.$ en $3^{\mathrm{e}}$ gr. $)$

- Docenten sociale vakken $\left(1^{\mathrm{e}} \mathrm{gr}\right.$. en WO)

- Docenten $2^{\mathrm{e}}$ en $3^{\mathrm{e}}$ graads zonder specialisatie

- Rij-instructeurs

- Bibliothecarissen

- Geestelijk verzorgers

- Conciërges

- Weg- en waterbouwkundigen

- Medisch analisten

- Juridisch en fiscaal medewerkers

Minste baanopeningen

- Zweminstructeurs

- Agrarische hulparbeiders

- Stewards

- Kantoorhulpen, inpakkers en colporteurs

- Ondersteunende administratieve hulpkrachten

- Economen

- Boekhouders en secretaresses

- Commercieel employés

- Commercieel medewerkers

- Technisch-bedrijfskundig medewerkers

- Activiteitenbegeleiders en medewerkers arbeidsbemiddeling

- Vakkenvullers

- Brandweerlieden

\section{Opleiding}

In tabel 3.7 zijn de verwachte baanopeningen naar opleidingscategorie voor Gelderland op de middellange termijn weergegeven als percentage van de werkgelegen- 
heid. Op de middellange termijn komt de totale vraag uit op $27 \%{ }^{30}$

De hoge totale vraag van de opleidingen Basisonderwijs, VMBO Theorie en HAVONWO is deels toe te schrijven aan het belang dat 'doorleerders' hebben binnen de vervangingsvraag voor deze opleidingen. Verder is de vraag groot voor VMBO Economie, HBO Onderwijs en sociaal-cultureel en HBO Paramedisch. Een erg lage vraag wordt verwacht voor HBO Economie en voor HBO Natuur en techniek en WO Natuur en techniek. Het percentage baanopeningen is voor de meeste opleidingscategorieën binnen $\mathrm{MBO}, \mathrm{HBO}$ en WO kleiner dan landelijk, met uitzondering van WO Medisch. Voor de lagere opleidingscategorieën en HAVONWO geldt juist het omgekeerde, met uitzondering van $V M B O$ Verzorging. Per saldo resulteert een groter percentage baanopeningen voor Gelderland dan voor Nederland, maar deze bijna ontstaan relatief vaak aan de onderkant van de arbeidsmarkt.

Tabel 3.7

Verwachte baanopeningen naar opleidingscategorie voor vijfjaarsperiode, als percentage van de werkgelegenheid in 2002, Gelderland en Nederland

\begin{tabular}{|c|c|c|}
\hline Opleidingscategorie & $\begin{array}{c}\text { Gelderland } \\
2003-2008 \\
\%\end{array}$ & $\begin{array}{c}\text { Nederland } \\
2003-2008 \\
\%\end{array}$ \\
\hline Basisonderwijs & 27 & 26 \\
\hline VMBO Theorie & 27 & 21 \\
\hline VMBO Natuur en techniek & 27 & 19 \\
\hline VMBO Economie & 36 & 30 \\
\hline VMBO Verzorging & 22 & 24 \\
\hline HAVO/VWO & 26 & 24 \\
\hline MBO Natuur en techniek & 22 & 26 \\
\hline MBO Economie & 21 & 23 \\
\hline MBO Dienstverlening en gezondheidszorg & 24 & 26 \\
\hline HBO Natuur en techniek & 20 & 24 \\
\hline HBO Economie & 16 & 17 \\
\hline HBO Onderwijs en sociaal-cultureel & 28 & 29 \\
\hline HBO Paramedisch & 28 & 34 \\
\hline WO Natuur en techniek & 17 & 22 \\
\hline WO Economie & 23 & 25 \\
\hline WO Letteren en sociaal-cultureel & 26 & 29 \\
\hline WO Medisch & 25 & 19 \\
\hline Totaal & 27 & 24 \\
\hline
\end{tabular}

Bron: ROA

In figuur 3.2 wordt het aandeel van de vervangingsvraag in het aantal baanopeningen weergegeven. Voor de meeste opleidingscategorieën geldt hetzelfde als wat voor de totale arbeidsmarkt geldt, namelijk dat de vervangingsvraag de voornaamste

30. Dit komt overeen met bijna 227.000 personen over de vijfjaarsperiode 2003-2008. De baanopeningen naar opleiding zijn groter dan de baanopeningen naar beroep. Dit komt doordat de vervangingsvraag naar opleiding verschilt van de vervangingsvraag naar beroep (zie aldaar, en zie ook Bijlage B). 
vraagcomponent voor nieuwe arbeidskrachten vormt. Vooral voor WO Medisch, WO Natuur en techniek en MBO Natuur en techniek is de vervangingsvraag relatief groot.

Figuur 3.2

Aandeel vervangingsvraag in de totale vraag, 2003-2008, Gelderland

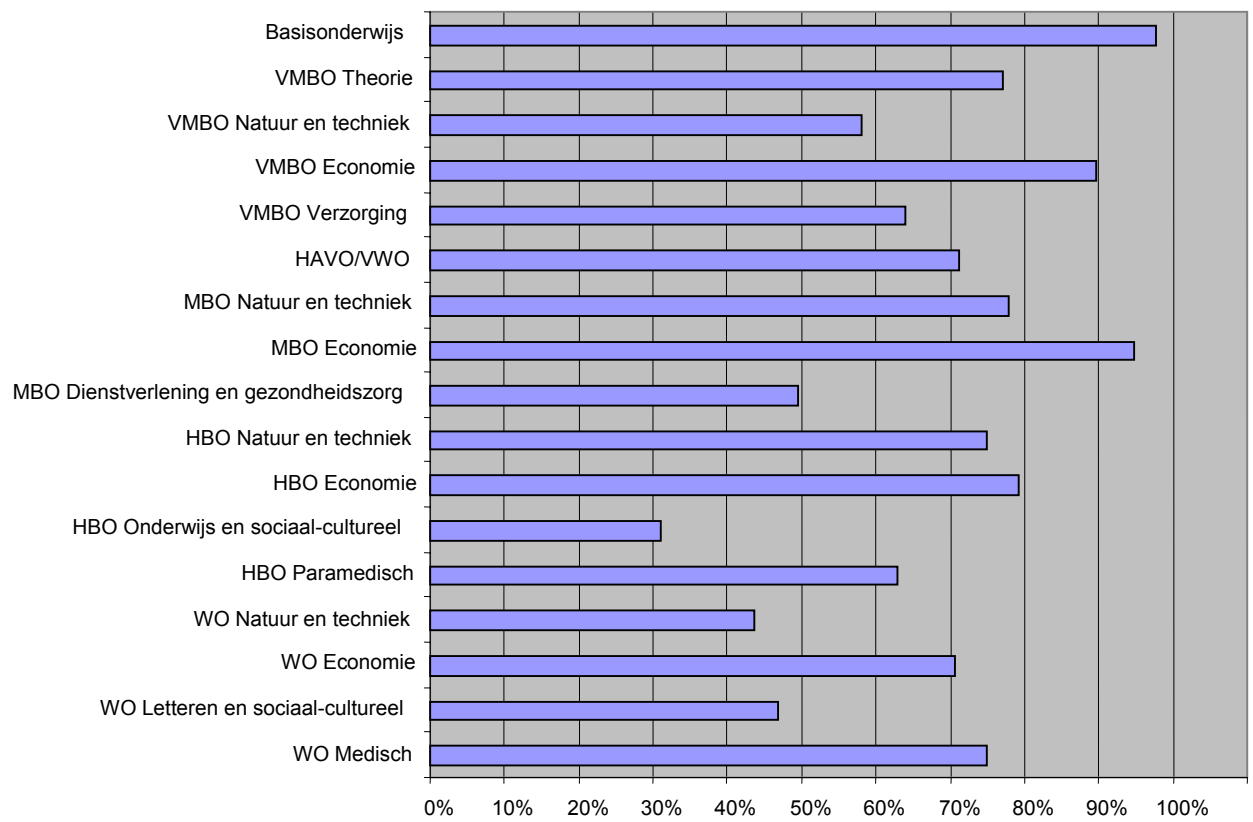

Bron: ROA

Opleidingstypen met de meeste en minste baanopeningen tot 2008, op basis van het percentage van het aantal werkenden per opleidingstype in 2002

Meeste baanopeningen

- VMBO voertuigentechniek

- VMBO grafische techniek

- VMBO beveiliging

- MBO horeca

- MBO gezondheidstechniek

- HBO bibliotheek en documentatie

- HBO lerarenopleiding economie en maatschappij

- HBO (fysio)therapie

- WO bouwkunde

- WO econom(etr)ie

Minste baanopeningen

- MBO fijnmechanische techniek

- HBO milieukunde en levensmiddelentechnologie

- HBO commerciële economie

- HBO voeding

- HBO toerisme en recreatie

- WO landbouw en milieukunde

- WO werktuigbouwkunde

- WO elektrotechniek

- WO theologie

- WO farmacie en medische biologie 
In het kader staan de opleidingstypen met relatief hoge of relatief lage percentages baanopeningen voor Gelderland. De verzameling van opleidingstypen met de hoogste percentages baanopeningen is redelijk gespreid over de verschillende opleidingsniveaus. De minste baanopeningen zijn vooral te vinden bij de opleidingstypen op HBO- en WO-niveau. 


\section{Knelpunten en perspectieven op de Gelderse arbeidsmarkt}

Bij het bepalen van de arbeidsmarktperspectieven voor schoolverlaters worden vraag en aanbod met elkaar geconfronteerd. De vraag bestaat uit het aantal baanopeningen, het aanbod uit de schoolverlaters die de arbeidsmarkt betreden. Met name schoolverlaters van Basisonderwijs (voornamelijk 'drop outs' van het VMBO), VMBO Economie en VMBO Verzorging kunnen op de middellange termijn moeite hebben met het vinden van een geschikte baan. De matige tot slechte middellangetermijnperspectieven voor deze opleidingscategorieën worden vooral veroorzaakt door de hoge instroom van schoolverlaters met een dergelijke opleidingsachtergrond op de arbeidsmarkt. Hoewel het aantal baanopeningen ten opzichte van Nederland groot is voor Basisonderwijs en VMBO Economie, wordt het aantal vrijkomende banen overtroffen door de grote instroom van schoolverlaters met een dergelijke opleidingsachtergrond. Voor VMBO Theorie en VMBO Natuur en techniek is het aantal baanopeningen relatief groot, terwijl de arbeidsmarktinstroom van schoolverlaters gemiddeld is. Dit resulteert per saldo in goede arbeidsmarktperspectieven voor schoolverlaters met dergelijke opleidingen.

Op MBO-niveau komen er zowel ten opzichte van het Gelderse gemiddelde als ten opzichte van Nederland relatief weinig banen vrij. Toch zijn de perspectieven voor MBO Natuur en techniek goed omdat er weinig schoolverlaters in de pijplijn van het onderwijs zitten. Dit geldt in mindere mate ook voor MBO Economie en MBO Dienstverlening en gezondheidszorg, waarvoor de arbeidsmarktperspectieven redelijk zijn. Toch worden er voor sommige opleidingstypen binnen deze twee richtingen slechte perspectieven verwacht. Daaronder vallen ook populaire opleidingstypen als MBO ICT en MBO sociaal-pedagogisch en welzijn. Deze slechte perspectieven worden geheel veroorzaakt door de erg hoge instroom van schoolverlaters met dergelijke opleidingen op de arbeidsmarkt. Opvallend zijn verder de goede arbeidsmarktperspectieven voor een aantal medisch-technische opleidingen. Van belang zijn tevens de mogelijkheden voor schoolverlaters om uit te wijken naar beroepen buiten het eigen beroependomein, welke voor het VMBO en de meer algemeen vormende opleidingen zoals HAVONWO wat groter zijn dan voor het MBO. De geringere uitwijkmogelijkheden op MBO-niveau hangen samen met de specialisatie die leerlingen ondergaan als zij binnen de beroepskolom doorleren.

Werkgevers kunnen tot 2008 zeer grote knelpunten in de personeelsvoorziening verwachten bij de Pedagogische beroepen. Hier is vooral de zeer lage instroom van afgestudeerden in combinatie met de grote vervangingsvraag debet aan. Bij de Pedagogische beroepen speelt ook een rol dat de substitutiemogelijkheden voor werkgevers, i.e. onderwijsinstellingen, beperkt zijn. Bij de Culturele beroepen en de Technische en industrieberoepen worden grote knelpunten in de personeelsvoorziening verwacht, ondanks dat voor de Technische en industrieberoepen op de middellange termijn een daling van de werkgelegenheid verwacht wordt. Over het algemeen zijn de substitutiemogelijkheden voor werkgevers tussen arbeidskrachten 
met een verschillende opleidingsachtergrond wat kleiner daar waar de rekruteringsproblemen op de arbeidsmarkt juist groot zijn.

Vrijwel geen knelpunten in de personeelsvoorziening worden verwacht bij de Economisch-administratieve beroepen, Sociaal-culturele beroepen, Agrarische beroepen, Transportberoepen en Verzorgende en dienstverlenende beroepen. Met name bij de Transportberoepen, de Economisch-administratieve beroepen en de Sociaal-culturele beroepen wordt dit veroorzaakt door een daling van de werkgelegenheid tezamen met een relatief lage vervangingsvraag.

\subsection{Inleiding}

In dit hoofdstuk zal worden ingegaan op de middellangetermijnprognoses van de ontwikkelingen op de Gelderse arbeidsmarkt tot 2008. De ontwikkelingen met betrekking tot de uitbreidingsvraag, vervangingsvraag, baanopeningen en instroom van schoolverlaters zijn al besproken in de voorgaande twee hoofdstukken. In dit hoofdstuk zullen de vraag- en aanbodcomponenten met elkaar worden geconfronteerd. Dit resulteert in indicatoren voor de arbeidsmarktperspectieven van schoolverlaters en indicatoren voor de knelpunten in de personeelsvoorziening voor werkgevers.

De arbeidsmarktperspectieven voor schoolverlaters op de arbeidsmarkt zal worden besproken aan de hand van de Indicator Toekomstige Arbeidsmarktsituatie (ITA) en de knelpunten in de personeelsvoorziening voor de werkgevers aan de hand van de Indicator Toekomstige Knelpunten in de personeelsvoorziening naar Beroep (ITKB). De Indicator Toekomstige Arbeidsmarktsituatie (ITA) geeft aan hoe groot de kansen zijn op de arbeidsmarkt voor schoolverlaters en werkzoekenden. Een ITA die veel groter is dan één geeft een ongunstige arbeidsmarktsituatie weer voor schoolverlaters en werkzoekenden. Indien de ITA namelijk groter is dan één is er meer aanbod van arbeid dan vraag. Door dit overschot aan arbeidskrachten op de arbeidsmarkt loopt men het risico langer naar een baan te moeten zoeken, eerder een baan te moeten accepteren die minder goed aansluit bij de gevolgde opleiding of minder goede arbeidsvoorwaarden biedt. Indien de ITA kleiner is dan één is er sprake van een gunstige arbeidsmarkt voor schoolverlaters en werkzoekenden. Het aanbod is dan kleiner dan de vraag.

Voor de werkgevers is het van belang een indicatie te krijgen van de knelpunten in de personeelsvoorziening die ze kunnen verwachten in de beroepen waarvoor ze personeel werven. De Indicator Toekomstige Knelpunten in de personeelsvoorziening naar Beroep (ITKB) geeft aan in welke mate het voor werkgevers mogelijk is om binnen beroepsgroepen de gewenste personele samenstelling wat betreft opleidingsachtergrond te realiseren. Hierbij wordt rekening gehouden met de vraag- en aanbodverhoudingen voor de verschillende opleidingstypen. De ITKB heeft een waarde tussen 0 en 1 en naarmate de indicator lager wordt, zijn de knelpunten groter voor de opleidingstypen die voor de betreffende beroepsgroep relevant zijn. De werkgevers zullen problemen ondervinden bij het aantrekken van personeel, dus er 
zullen knelpunten optreden op het betreffende segment van de arbeidsmarkt. Naarmate de ITKB dichter bij 1 ligt, zullen werkgevers weinig moeite hebben de gewenste personele samenstelling te realiseren.

$\mathrm{Bij}$ een aanbodoverschot is het niet vanzelfsprekend dat schoolverlaters werkloos zullen worden, evenals dat het bij een vraagoverschot niet vanzelfsprekend is dat er onvervulde vacatures zijn. Het is namelijk ook mogelijk dat werkgevers hun eisen aanpassen aan de arbeidsmarktsituatie op het moment dat ze personeel proberen te werven. Bij een vraagoverschot op specifieke opleidingssegmenten zouden werkgevers ook personeel kunnen werven dat niet volledig beschikt over de benodigde kwalificaties. Deze personen zouden indien nodig met om- of bijscholingsprogramma's opgeleid kunnen worden om na enige tijd aan de kwalificatievereisten voor de banen met knelpunten in de personeelsvoorziening te voldoen.

In paragraaf 4.2 worden de middellangetermijnperspectieven naar opleidingscategorie gepresenteerd. Vervolgens worden in paragraaf 4.3 de knelpunten in de personeelsvoorziening naar beroep voor de middellange termijn besproken. In paragraaf 4.4 komen de mogelijkheden voor schoolverlaters aan de orde als zij vanwege een ongunstig arbeidsmarktperspectief buiten hun beroependomein zouden willen werken. Tevens wordt aangegeven welke mogelijkheden werkgevers hebben om bij arbeidsmarktkrapte personeel te werven met een andere opleidingsachtergrond dan in eerste instantie gewenst.

\subsection{De arbeidsmarktperspectieven voor schoolverlaters}

Tabel 4.1 presenteert de Indicator Toekomstig Arbeidsmarktsituatie (ITA) met bijbehorende typeringen voor Gelderland voor de lagere en middelbare opleidingscategorieën. Deze indicator geeft voor elke opleidingscategorie de verhouding tussen het arbeidsaanbod met de betreffende opleidingsachtergrond en de daar tegenoverstaande vraag. Als het arbeidsaanbod kleiner is dan de vraag (dit komt overeen met een ITA die kleiner of gelijk is aan 1,00) wordt het arbeidsmarktperspectief als goed of zeer goed getypeerd. Schoolverlaters en werkzoekenden zullen relatief gemakkelijk een baan vinden in de beroepsgroep waarvoor hun opleidingsachtergrond vereist is. Voor werkgevers daarentegen zal het juist moeilijk zijn om schoolverlaters met deze opleidingsachtergrond aan te trekken. Een goed arbeidsmarktperspectief voor schoolverlaters en werkzoekenden zal doorgaans samenvallen met grote knelpunten in de personeelsvoorziening voor werkgevers.

Tabel 4.1 laat zien dat de arbeidsmarktperspectieven voor de schoolverlaters van de lagere opleidingen aanzienlijke kunnen verschillen tussen richtingen. Met name schoolverlaters van Basisonderwijs (voornamelijk 'drop outs' van het VMBO), VMBO Economie en $V M B O$ Verzorging kunnen op de middellange termijn moeite hebben met het vinden van een geschikte baan. De matige tot slechte middellangetermijnperspectieven voor deze opleidingscategorieën worden vooral veroorzaakt door de hoge instroom van schoolverlaters met een dergelijke opleidingsachtergrond op de arbeidsmarkt. Hoewel het aantal baanopeningen ten opzichte van Nederland groot is 
voor Basisonderwijs en VMBO Economie, wordt het aantal vrijkomende banen overtroffen door de grote instroom van schoolverlaters met een dergelijke opleidingsachtergrond. Voor VMBO Theorie en VMBO Natuur en techniek is het aantal baanopeningen relatief groot, terwijl de arbeidsmarktinstroom van schoolverlaters gemiddeld is. Dit resulteert per saldo in goede arbeidsmarktperspectieven voor schoolverlaters met dergelijke opleidingen.

Op MBO-niveau komen er zowel ten opzichte van het Gelderse gemiddelde als ten opzichte van Nederland relatief weinig banen vrij. Toch zijn de perspectieven voor $M B O$ Natuur en techniek gunstig omdat er weinig schoolverlaters in de pijplijn van het onderwijs zitten. Dit geldt in mindere mate ook voor $M B O$ Economie en $M B O$ Dienstverlening en gezondheidszorg, waarvoor de perspectieven gemiddeld genomen redelijk zijn.

Tabel 4.1

Indicator Toekomstige Arbeidsmarktsituatie (ITA) per opleidingscategorie tot 2008, Gelderland en Nederland

\begin{tabular}{llll}
\hline & \multicolumn{2}{c}{ Gelderland } & Nederland \\
Opleidingscategorie & ITA & Typering & Typering \\
& & & \\
& & & matig \\
Basisonderwijs & 1,06 & matig & matig \\
VMBO Theorie & 0,99 & goed & slecht \\
VMBO Natuur en techniek & 1,00 & goed & slecht \\
VMBO Economie & 1,23 & slecht & slecht \\
VMBO Verzorging & 1,09 & matig & matig \\
HAVO/VWO & 1,06 & matig & goed \\
MBO Natuur en techniek & 1,00 & goed & matig \\
MBO Economie & 1,03 & redelijk & redelijk \\
MBO Dienstverlening en gezondheidszorg & 1,05 & redelijk & \\
\hline Bron: ROA & & &
\end{tabular}

Bron: ROA

De opleidingen met de beste en slechtste arbeidsmarktperspectieven

Bijgaand kader geeft een overzicht van de opleidingstypen met de beste en slechtste arbeidsmarktperspectieven voor schoolverlaters in Gelderland. Zo blijkt dat de meeste opleidingstypen met de beste arbeidsmarktperspectieven tot de richting natuur en techniek behoren, in overeenstemming met de eerder geconstateerde goede perspectieven voor schoolverlaters binnen de opleidingscategorieën VMBO Natuur en techniek en MBO Natuur en techniek. Opvallend zijn verder de goede arbeidsmarktperspectieven voor $M B O$ apothekersassistent en voor een aantal min of meer verwante medisch-technische opleidingsrichtingen. In paragraaf 3.2 werd overigens al geconstateerd dat de uitbreidingsvraag voor een aantal medischtechnische beroepen erg hoog is.

Slechte arbeidsmarktperspectieven worden verwacht voor een aantal opleidingstypen binnen de richtingen economie en gezondheidszorg. Daaronder vallen ook populaire opleidingstypen als MBO ICT en MBO sociaal-pedagogisch en welzijn. De slechte perspectieven van de in het kader vermelde opleidingstypen worden geheel 
veroorzaakt door de erg hoge instroom van schoolverlaters op de arbeidsmarkt. De baanopeningen als percentage van de werkgelegenheid wijken namelijk voor de genoemde opleidingstypen niet veel van het gemiddelde van Gelderland af.

Lagere en middelbare opleidingstypen met beste en slechtste arbeidsmarktperspectieven voor schoolverlaters en werkzoekenden in Gelderland tot 2008

Beste perspectieven

- VMBO voertuigentechniek

- $\quad$ VMBO grafische techniek

- VMBO fijnmechanische techniek

- $\quad \mathrm{MBO}$ groene ruimte

- MBO bouw

- $\quad \mathrm{MBO}$ gezondheidstechniek

- MBO apothekersassistent

- MBO laboratorium

- $\quad \mathrm{MBO}$ levensmiddelentechniek/vleesverwerking

Slechtste perspectieven

- $\quad$ VMBO administratie, handel en mode

- VMBO installatietechniek

- $\quad \mathrm{MBO}$ facilitaire dienstverlening

- $\quad$ MBO ICT

- $\quad M B O$ sociaal-pedagogisch en welzijn

- MBO geld, bank en belastingen

\subsection{Knelpunten in de personeelsvoorziening voor werkgevers}

Werkgevers zullen voor bepaalde functies knelpunten bij de vervulling van vacatures ondervinden. Op deze functies kunnen vaak schoolverlaters en werkzoekenden met een uiteenlopende opleidingsachtergrond worden ingezet. De Indicator Toekomstige Knelpunten in de personeelsvoorziening naar Beroep (ITKB) houdt rekening met de verwachte schaarste op de arbeidsmarkt voor de verschillende relevante opleidingstypen per beroep. Indien er een sterke één-op-één relatie is tussen opleiding en beroep, zoals in de zorg en het onderwijs, komt de verwachte vraag-aanbod verhouding voor deze opleidingen en beroepen grotendeels overeen. In dat geval zijn de strategieën voor werkgevers om de tekorten op te vangen beperkt door de geringe substitutiemogelijkheden tussen schoolverlaters met een uiteenlopende opleidingsachtergrond. De opleidingsvereisten in met name de zorg en het onderwijs liggen in belangrijke mate vast, waardoor werkgevers op dit punt weinig flexibel kunnen zijn in hun aannamebeleid. ${ }^{31}$

31. Zie voor de zorg in vergelijking met de metaal en de ICT bijvoorbeeld W. Smits (2001), Wie willen werkgevers? Personeelsselectie in de Zorg, Metaalindustrie en de IT, ROA2001/2, Maastricht. 
Tabel 4.2 geeft de ITKB met bijbehorende typeringen weer voor Gelderland en Nederland per beroepsklasse. Hieruit blijkt dat voor werkgevers in Gelderland de knelpunten in de personeelsvoorziening op de middellange termijn groot of zeer groot zullen zijn voor de Pedagogische beroepen, de Culturele beroepen en de Technische en industrieberoepen.

Vergeleken met Nederland zullen Gelderse werkgevers doorgaans vooral voor de Culturele beroepen en de Technische en industrieberoepen meer moeite doen om geschikt personeel te werven. In de Sociaal-culturele beroepen, Medische en paramedische beroepen en de Openbare orde- en veiligheidsberoepen zullen de knelpunten in de personeelsvoorziening voor Gelderse werkgevers kleiner zijn dan landelijk.

Tabel 4.2

Indicator Toekomstige Knelpunten in de personeelsvoorziening naar Beroep (ITKB) per beroepsklasse tot 2008, Gelderland en Nederland

\begin{tabular}{|c|c|c|c|}
\hline \multirow[b]{2}{*}{ Beroepsklasse } & \multicolumn{2}{|c|}{ Gelderland } & \multirow{2}{*}{$\begin{array}{l}\text { Nederland } \\
\text { Typering }\end{array}$} \\
\hline & ITKB & Typering & \\
\hline Pedagogische beroepen & 0,89 & zeer groot & groot \\
\hline Culturele beroepen & 0,90 & groot & enige \\
\hline Agrarische beroepen & 0,96 & vrijwel geen & geen \\
\hline Technische en industrie beroepen & 0,91 & groot & vrijwel geen \\
\hline Transportberoepen & 0,96 & vrijwel geen & geen \\
\hline Medische en paramedische beroepen & 0,92 & enige & groot \\
\hline Economisch-administratieve beroepen & 0,95 & vrijwel geen & enige \\
\hline Informaticaberoepen & 0,93 & enige & enige \\
\hline Sociaal-culturele beroepen & 0,95 & vrijwel geen & groot \\
\hline Verzorgende en dienstverlenende beroepen & 0,97 & vrijwel geen & geen \\
\hline Openbare orde- en veiligheidsberoepen & 0,92 & enige & groot \\
\hline
\end{tabular}

\section{Bron: ROA}

De knelpunten in de personeelsvoorziening bij de Pedagogische beroepen worden vooral veroorzaakt door de zeer lage instroom van afgestudeerden op de arbeidsmarkt in combinatie met een hoge uitbreidings- en vervangingsvraag. Voor Gelderland is bovendien de uitbreidingsvraag nog groter dan voor Nederland. Bij de Pedagogische beroepen speelt ook een rol dat de substitutiemogelijkheden voor werkgevers beperkt zijn. Ook bij de Culturele beroepen en de Technische en industrieberoepen worden grote knelpunten in de personeelsvoorziening verwacht. Dit wordt bij de Technische en industrieberoepen met name veroorzaakt doordat er zo weinig belangstelling is voor het volgen van een technische opleiding, dat de baanopeningen die ontstaan door de relatief grote vervangingsvraag in Gelderland niet opgevuld kunnen worden.

Vrijwel geen knelpunten in de personeelsvoorziening worden verwacht bij de Economisch-administratieve beroepen, de Sociaal-culturele beroepen, de Agrarische beroepen, de Transportberoepen en de Verzorgende en dienstverlenende beroepen. Met name bij de Transportberoepen, de Economisch-administratieve beroepen en de 
Sociaal-culturele beroepen wordt dit veroorzaakt door een daling in de werkgelegenheid van deze beroepsklassen tezamen met een relatief lage vervangingsvraag.

\section{De beroepen met de grootste en kleinste knelpunten in de personeelsvoorziening}

Aan de hand van de knelpunten in de personeelsvoorziening voor werkgevers bij de verschillende beroepsklassen kunnen de achterliggende beroepsgroepen bekeken worden. Uit tabel 4.2 is bijvoorbeeld gebleken dat op de middellange termijn grote knelpunten verwacht kunnen worden bij de Technische en industrieberoepen. Echter, niet alle werkgevers die een vacature open hebben staan in deze beroepsklasse zullen geconfronteerd worden met knelpunten in de personeelsvoorziening. Aangezien de vooruitzichten voor een beroepsklasse niet identiek zijn voor alle onderliggende beroepsgroepen wordt in onderstaand schema een overzicht van de beroepsgroepen gegeven waarvoor Gelderse werkgevers relatief veel dan wel weinig knelpunten in de personeelsvoorziening kunnen verwachten. Wij zullen hierbij alleen de lagere en middelbare beroepsgroepen weergeven, omdat het aanbod op de arbeidsmarkt voor de hogere beroepsgroepen niet zonder meer aan een regio kan worden toegerekend in verband met de grote geografische mobiliteit van hoger opgeleiden. ${ }^{32}$

Lagere en middelbare beroepsgroepen met de meeste en minste knelpunten in de personeelsvoorziening voor werkgevers in Gelderland tot 2008

Meeste knelpunten

- Aannemers en installateurs

- Bankwerkers en lassers

- Elektronicamonteurs

- Apothekersassistenten en medische laboranten

- Hoofden technische dienst

Minste knelpunten

- Rij-instructeurs

- Agrarische hulparbeiders

- Landbouwmachinebestuurders en vissers

- Laboratorium-assistenten

- Conciërges

- Confectie-arbeiders

- Schoen- en kleermakers

- Verpleeghulpen en leerling-verpleegkundigen

- Ondersteunende administratieve hulpkrachten

- Administratieve transportemployés

- Vakkenvullers

- Interieurverzorgers

- Verkopers

- Winkeliers

32. In tabel 4.2 is dat overigens wel gedaan voor de hogere beroepsgroepen binnen een beroepsklasse. 
In het bijgaande kader wordt een overzicht gegeven van de beroepsgroepen met de meeste en de minste rekruteringsproblemen op de middellange termijn. Het valt op dat er vooral voor de middelbare beroepsgroepen uit de Technische en industrieberoepen erg grote rekruteringsproblemen voor werkgevers worden verwacht. Ondanks de krimp in de werkgelegenheid die verwacht wordt bij deze beroepsgroepen zijn de te verwachten rekruteringsproblemen erg groot. Alleen bij de hoofden technische dienst is de grote vervangingsvraag daarvoor mede verantwoordelijk, voor de overige beroepsgroepen speelt uitsluitend de geringe instroom op de arbeidsmarkt van schoolverlaters met een middelbare technische beroepsopleiding een rol.

Over het algemeen worden geen rekruteringsproblemen verwacht voor de elementaire en lagere technische beroepsgroepen waarvoor nauwelijks of geen scholing is vereist. Functies op lager niveau komen in alle onderscheiden beroepsklassen voor. De meeste beroepsgroepen die genoemd worden in het kader hebben weinig baanopeningen. Alleen voor rij-instructeurs en conciërges worden veel baanopeningen verwacht. Ook voor deze beroepsgroepen overtreft de arbeidsmarktinstroom echter het aantal baanopeningen.

\subsection{Uitwijk- en substitutiemogelijkheden op de arbeidsmarkt}

De uitwijkmogelijkheden voor schoolverlaters om in tijden van een ruimere arbeidsmarkt te kunnen veranderen van beroep of sector houden verband met de structurele positie van opleidingen. Opleidingen staan voor een bepaald curriculum dat kan variëren van smal en specialistisch tot een breed en algemeen. Veranderingen in het curriculum door bijvoorbeeld een verbreding van opleidingen, kunnen leiden tot een breder beroependomein. Hierdoor wordt de afhankelijkheid van deze opleidingen van een beperkt aantal beroepen verminderd. Aan de andere kant kunnen technologische ontwikkelingen ertoe leiden dat er behoefte ontstaat aan specifiek opgeleid personeel. Hierdoor kan het wenselijk zijn dat onderwijsinstellingen juist meer specialistische opleidingen aanbieden.

In deze paragraaf wordt de arbeidsmarktkansen voor verschillende opleidingsrichtingen op VMBO- en MBO-niveau weergegeven door de toekomstige arbeidsmarktperspectieven op de Gelderse arbeidsmarkt af te zetten tegen de uitwijkmogelijkheden. Tevens zal aangegeven worden in welke mate werkgevers arbeidskrachten met een verschillende opleidingsachtergrond kunnen inzetten als zij geconfronteerd worden met knelpunten in de personeelsvoorziening. Dit zijn de zogenaamde substitutiemogelijkheden voor werkgevers. Indien werkgevers afhankelijk zijn van het arbeidsaanbod van één bepaald opleidingstype zullen de substitutie- 
mogelijkheden beperkt zijn. ${ }^{33}$

\section{Uitwijkmogelijkheden voor schoolverlaters}

De mate waarin schoolverlaters met een bepaalde opleiding afhankelijk zijn van de arbeidsmarktsituatie binnen één bepaalde beroepsgroep is een maatstaf voor het risico van deze opleiding op de arbeidsmarkt. ${ }^{34}$ Dit risico is vooral groot bij opleidingen die specifiek gericht zijn op functies in een bepaalde vakdeelmarkt. Een voorbeeld van een specialistische vakdeelmarkt is de arbeidsmarkt voor apothekersassistenten. Gediplomeerde apothekersassistenten zijn specifiek opgeleid en hun expertise is in heel weinig andere beroepsgroepen vereist. Derhalve zal deze groep schoolverlaters, wanneer het werkgelegenheidsperspectief minder gunstig is, betrekkelijk moeilijk kunnen uitwijken naar beroepen waarvoor de perspectief op een baan gunstiger is.

Degenen die daarentegen een opleiding hebben gevolgd waarmee men in diverse beroepsgroepen aan de slag kan, hebben een grotere kans uit te kunnen wijken naar beroepen waarvoor de werkgelegenheidsperspectieven gunstiger zijn. In dit geval is er sprake van een vorm van risicospreiding. Het volgen van een brede opleiding is overigens niet in alle gevallen positief voor de kansen op de arbeidsmarkt. Indien de uitwijkmogelijkheden groot zijn impliceert dit immers ook dat de schoolverlaters meer concurrentie ondervinden van schoolverlaters met een andere opleidingsachtergrond. Tevens kan een verbreding van de opleiding ten koste gaan van de specialisatie waardoor de productiviteit, c.q. de directe inzetbaarheid van de schoolverlaters, geringer wordt.

Figuur 4.1 laat zien hoe groot de uitwijkmogelijkheden naar de verschillende beroepen zijn in combinatie met de toekomstige arbeidsmarktperspectieven voor schoolverlaters in Gelderland. Vooral MBO-opleidingen blijken minder mogelijkheden te bieden om uit wijken naar verschillende beroepen. Daar staat tegenover dat deze opleidingen over het algemeen ook iets betere perspectieven bieden op het eigen beroependomein. De geringere uitwijkmogelijkheden op MBO-niveau hangen samen met de specialisatie die leerlingen ondergaan als zij binnen de beroepskolom doorleren. Op het VMBO is nog nauwelijks sprake van het verwerven van beroepsgerichte vaardigheden. Overigens kunnen de arbeidsmarktperspectieven c.q. de uitwijkmogelijkheden van de opleidingstypen binnen de opleidingscategorieën die in

33. De indicatoren voor de uitwijk- en substitutiemogelijkheden in deze paragraaf zijn gebaseerd op landelijke gegevens, mede in verband met de betrouwbaarheid van de vereiste regionale arbeidsmarktgegevens. Uit eerder onderzoek is echter gebleken dat deze indicatoren niet veel verschillen tussen regio's en Nederland als geheel. Zie RAMING Digitaal (Bijlage $C$ ) voor een volledig overzicht van de uitwijk- en substitutiemogelijkheden per opleidingstype of beroepsgroep. Zie paragraaf 5.4 voor de mogelijkheden van schoolverlaters en werkgevers om uit te wijken naar andere provincies respectievelijk om het arbeidsaanbod in andere provincies aan te boren.

34. Een andere risico-indicator is de conjunctuurgevoeligheid van de werkgelegenheid. Deze geeft de mate van baanzekerheid aan voor sectoren, beroepsgroepen of opleidingstypen. Zie RAMING Digitaal. 
figuur 4.1 genoemd worden, nog aanzienlijk uiteenlopen. Zo heeft het opleidingstype MBO apothekersassistent binnen MBO Dienstverlening en gezondheidszorg een zeer goed arbeidsmarktperspectief met erg lage uitwijkmogelijkheden, terwijl $M B O$ verzorging behorend tot dezelfde opleidingscategorie, een matig perspectief heeft met gemiddelde uitwijkmogelijkheden. ${ }^{35}$

Figuur 4.1

De arbeidsmarktperspectieven en uitwijkmogelijkheden voor schoolverlaters in Gelderland

\section{Erg hoge uitwijkmogelijkheden}

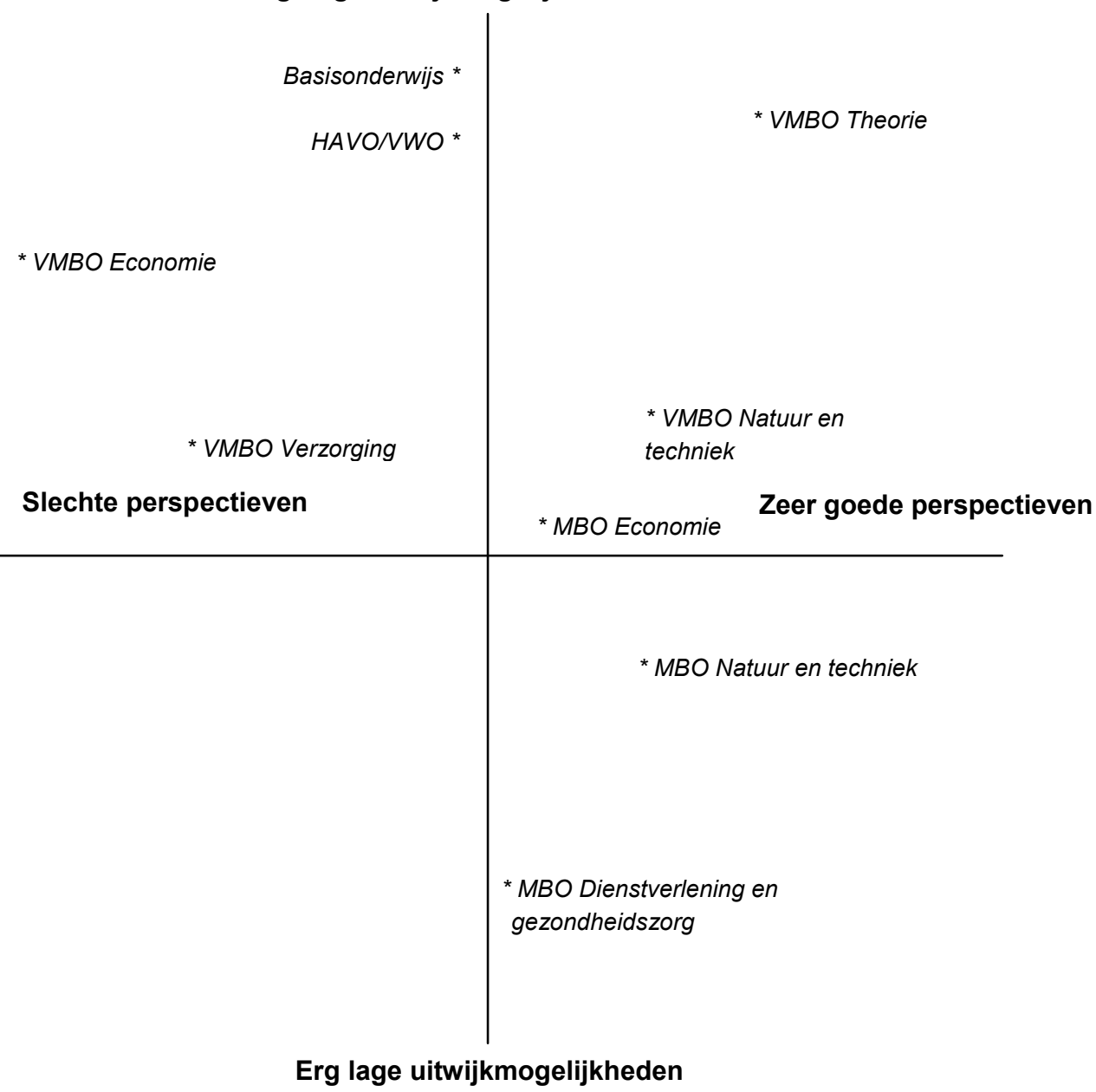

Erg lage uitwijkmogelijkheden

35. In Bijlage B is weergegeven welke opleidingstypen behoren tot een bepaalde opleidingscategorie. Zie RAMING Digitaal voor informatie over de verschillende opleidingstypen. Behalve een indicator voor de uitwijkmogelijkheden naar beroep is daarin ook een indicator opgenomen voor de uitwijkmogelijkheden naar sector. 
Substitutiemogelijkheden voor werkgevers

De substitutiemogelijkheden voor de werkgevers zijn van belang in verband met de verwachte knelpunten in de personeelsvoorziening zoals deze gepresenteerd werden in paragraaf 4.3. De substitutiemogelijkheden voor werkgevers geven aan in hoeverre werkgevers arbeidskrachten kunnen aantrekken met uiteenlopende opleidingsachtergronden. Indien werkgevers afhankelijk zijn van het arbeidsaanbod van één bepaald opleidingstype zullen de substitutiemogelijkheden beperkt zijn. De substitutiemogelijkheden voor de werkgevers worden bepaald aan de hand van een spreidingsindex van opleidingen binnen de beroepsgroepen.

Figuur 4.2

De knelpunten in de personeelsvoorziening en de substitutiemogelijkheden voor werkgevers in Gelderland

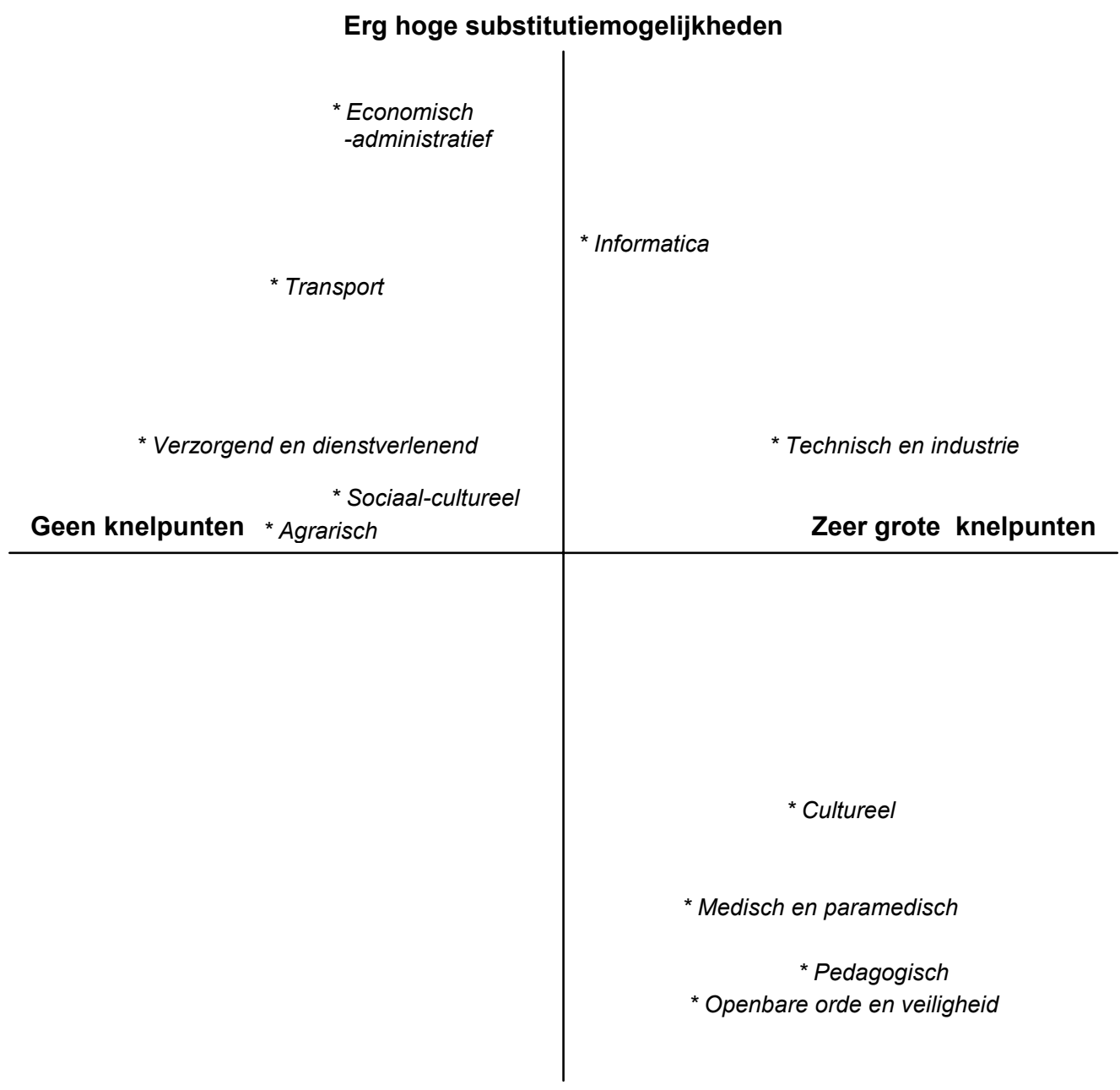

Erg lage substitutiemogelijkheden 
Figuur 4.2 zet de substitutiemogelijkheden van werkgevers af tegen de knelpunten in de personeelsvoorziening. De figuur laat zien dat voor de Pedagogische beroepen en de Culturele beroepen de knelpunten in de personeelsvoorziening (zeer) groot zullen zijn terwijl de substitutiemogelijkheden beperkt zijn. Onderwijsinstellingen die op zoek zijn naar personeel voor de openstaande vacatures zullen niet veel mogelijkheden hebben afgestudeerden aan te trekken zonder een pedagogische opleidingsachtergrond. Binnen de Culturele beroepen zijn de substitutiemogelijkheden vooral beperkt voor de bibliothecarissen, geestelijk verzorgers en geestelijken. Voor de beroepsgroepen van journalisten en taalkundigen, eveneens behorend tot de Culturele beroepen, zijn er daarentegen relatief veel substitutiemogelijkheden tussen opleidingen.

Voor de Technische en industrieberoepen geldt dat er grote knelpunten verwacht worden in de personeelsvoorziening, terwijl de substitutiemogelijkheden voor werkgevers binnen deze beroepen gemiddeld zijn. Er is echter sprake van een grote variatie aan substitutiemogelijkheden voor de verschillende Technische en industrieberoepen: de substitutiemogelijkheden zijn bijvoorbeeld hoog voor de monteurs, maar laag voor de elektronicamonteurs (zie voor meer details RAMING Digitaal). Voor de Medische en paramedische beroepen en de Openbare orde- en veiligheidsberoepen geldt over het algemeen dat de substitutiemogelijkheden beperkt zijn. Hier worden voor sommige beroepen grote rekruteringsproblemen voor werkgevers verwacht, zoals voor de apothekersassistenten en medisch analisten respectievelijk de politieagenten, onderofficieren en beveiligingsemployés. Ook binnen de Informaticaberoepen treden er enige rekruteringsproblemen op, maar hier zijn de substitutiemogelijkheden aanzienlijk groter. Over het algemeen zijn de substitutiemogelijkheden voor werkgevers tussen arbeidskrachten met een verschillende opleidingsachtergrond wat kleiner daar waar de rekruteringsproblemen op de arbeidsmarkt juist groot zijn. 


\section{Geografische mobiliteit van schoolverlaters en werkenden}

Een grotere geografische mobiliteit van personen kan ertoe leiden dat het aanbod beter aansluit bij de vraag op de regionale arbeidsmarkt. Zo hebben werkzoekenden doorgaans een grotere kans op een baan die aansluit bij het behaalde opleidingsniveau indien hun zoekgebied meerdere lokale arbeidsmarkten beslaat. Voor Gelderse schoolverlaters van het VMBO, MBO en HBO geldt dat de inpassing in het arbeidsproces redelijk goed is ten opzichte van het landelijke gemiddelde. Gelderse schoolverlaters leggen gemiddeld een afstand van 31 kilometer naar hun baan, en zijn daarmee iets mobieler dan de gemiddelde schoolverlater in Nederland (28 kilometer). De arbeidsmarktintrede verloopt voor de Gelderse schoolverlaters doorgaans beter dan gemiddeld wat betreft het niveau en richting van de baan waarop men anderhalf jaar na afstuderen terecht komt. Zo heeft $74 \%$ van de schoolverlaters een baan op niveau gevonden. Hetzelfde geldt voor een baan in de eigen vakrichting. Gelderse schoolverlaters hebben echter een relatief lage kans op het vinden van een vaste of een voltijdbaan.

In vergelijking met Nederland blijken werkenden in Gelderland echter gemiddeld iets dichter bij hun werk te wonen. Hoewel de reisafstanden en -tijden zijn gestegen tussen 1991 en 2001, is de provinciegrensoverschrijdende pendel nauwelijks toegenomen in deze periode. Als de mobiliteit wordt uitgesplitst naar de vier COROPregio's in de provincie dan blijkt wel dat de inkomende pendel van buiten elke COROP-regio aanzienlijk is toegenomen. De oorzaak van dit patroon is dat mensen in steeds sterkere mate naar het westen gaan om te werken en dus in het oosten of noordoosten van hun werk wonen. Verder blijkt dat ook steeds meer inwoners uit Gelderland buiten hun COROP-gebied gaan werken. Inmiddels is ook in de regio Arnhem/Nijmegen de uitgaande pendel groter dan de inkomende pendel. Vooral onder hoger opgeleide mannen in Zuidwest-Gelderland wordt de Randstad steeds duidelijker de belangrijkste regio voor werkgelegenheid. Omgekeerd blijken mensen van buiten de provincie Gelderland vooral in Zuidwest-Gelderland te werken.

De grootste leverancier van werkenden in Gelderland is de provincie Overijssel. Vanuit Overijssel en Zuid-Holland komen meer mensen werken in Gelderland dan dat er werkenden uit Gelderland naar die provincies gaan. Voor Utrecht en NoordHolland ligt die verhouding omgekeerd. Per saldo gaat hier een grotere stroom van mensen die in Gelderland wonen, werken in deze provincies. Bij Noord-Brabant en Limburg is de balans ongeveer in evenwicht.

Nagegaan is welke effecten een werkgelegenheidstoename in de provincie Gelderland heeft op de inkomende pendel, de bevolkingsomvang en de participatiegraad. Ongeveer 15\% van de werkgelegenheidstoename tot 2008 zal naar verwachting vervuld worden door werkenden uit naburige provincies. Het grootste deel van deze nieuwe werkenden van buiten Gelderland komt uit Utrecht (4,3\%), gevolgd door Overijssel (3,4\%) en Noord-Brabant (3,2\%). Met name in de Veluwe en ZuidwestGelderland trekt de werkgelegenheidsgroei in de provincie relatief veel pendelaars uit 
andere provincies aan. De invloed van toenemende werkgelegenheid op de participatiegraad in buurgemeenten, lijkt in Gelderland groter te zijn dan in de rest van het land. Daarnaast is de verwachting dat bijna $10 \%$ van de werkgelegenheidstoename vervuld zal worden door mensen die naar Gelderland verhuizen. De instroom van mensen die naar Gelderland verhuizen vanwege de werkgelegenheidstoename is relatief groot onder de hoger opgeleiden. De toename van de bevolking is in Zuidwest-Gelderland iets lager dan in de drie andere COROP-gebieden.

Een toename van de pendelstromen of de arbeidsmarktinstroom van schoolverlaters vanuit omliggende provincies zou een verlichting kunnen betekenen voor de toekomstige rekruteringsproblemen van Gelderse werkgevers in sommige beroepsklassen. Uit de analyses blijkt dat de verwachte rekruteringsproblemen voor Gelderse onderwijsinstellingen (zie hoofdstuk 4) slechts in zeer beperkte mate opgelost kunnen worden door verschuivingen in het regionale arbeidsaanbod te bewerkstelligen, temeer omdat de knelpunten voor de Pedagogische beroepen in de rest van Nederland nog groter zijn. Voor de Technische en industrieberoepen geldt dat een stijging van $1 \%$ van het arbeidsaanbod van inkomende pendelaars of schoolverlaters leidt tot het oplossen van de knelpunten in de personeelsvoorziening in Gelderland. Dit is een aantrekkelijke optie, mede omdat de rekruteringsproblemen voor de Technische en industrieberoepen kleiner zijn in de rest van Nederland dan in Gelderland. Voor de Culturele beroepen is dit moeilijker, omdat de vereiste verandering in het regionale Gelderse arbeidsaanbod groter is. Bovendien zijn er voor deze beroepen ook enige knelpunten in de personeelsvoorziening in de rest van Nederland.

\section{$5.1 \quad$ Inleiding}

In dit hoofdstuk komt de geografische mobiliteit van schoolverlaters en werkenden op de Gelderse arbeidsmarkt aan de orde. In paragraaf 5.2 wordt gekeken naar de regio waar schoolverlaters van VMBO, MBO of HBO in Gelderland terecht komen als ze een baan gevonden hebben, en hoe daarbij de kwaliteit van de aansluiting tussen onderwijs en arbeidsmarkt is. In paragraaf 5.3 wordt onderzocht in welke mate een toename van de werkgelegenheid in Gelderland een stijging van de inkomende pendel, de bevolking of de participatiegraad tot gevolg heeft. Daarbij wordt onderscheid gemaakt tussen de vier COROP-gebieden in Gelderland, en tussen grote en kleine gemeenten. Bovendien is er aandacht voor verschillen in mobiliteit van personen naar geslacht en opleidingsniveau. Tot slot wordt in paragraaf 5.4 nagegaan of en in welke mate aanpassingen in regionale mobiliteitsstromen een oplossing kunnen zijn voor tekorten en overschotten op de Gelderse arbeidsmarkt. In deze paragraaf wordt de mobiliteit besproken van twee groepen die in de voorgaande twee paragrafen aan de orde kwamen, namelijk de schoolverlaters die na hun afstuderen een baan vinden in Gelderland of daarbuiten, en de inkomende pendelaars die buiten Gelderland wonen, maar in Gelderland werkzaam zijn. 


\subsection{Geografische mobiliteit en intrede op de arbeidsmarkt}

Verschillen tussen vraag en aanbod van arbeid kunnen leiden tot werkloosheid of onvervulde vacatures. Om werkloosheid te voorkomen kunnen werkzoekenden hun zoekgedrag aanpassen door een baan te accepteren die minder goed aansluit bij de verworven kennis en vaardigheden. Het gevolg daarvan is dat werkzoekenden in plaats van werkloos te blijven een baan accepteren waarvoor ze in feite een te hoog opleidingsniveau hebben. $\mathrm{Er}$ is dan sprake van overscholing. $\mathrm{Er}$ zijn aanwijzingen dat het gemiddelde opleidingsniveau van de Nederlandse beroepsbevolking sterker is gestegen dan het niveau van de beschikbare banen. ${ }^{36}$ Hierdoor zouden er steeds meer personen in Nederland werkzaam zijn in banen onder het behaalde opleidingsniveau. Naast het aanvaarden van een baan onder het behaalde opleidingsniveau kunnen werkzoekenden hun zoekgedrag ook aanpassen door een baan buiten het eigen beroependomein te accepteren om werkloosheid te voorkomen. ${ }^{37}$ De mate waarin een baan aansluit bij de behaalde opleiding, en de beloning of de baanzekerheid $^{38}$ worden echter door werkzoekenden verschillend gewaardeerd. Werkzoekenden maken een persoonlijke keuze bij het afwegen van de verschillende baankenmerken tegen elkaar af als zij solliciteren op de openstaande vacatures.

De kans op overscholing kan worden verminderd wanneer werkzoekenden bereid zijn een grotere afstand af te leggen om de werklocatie te bereiken. Een grote afstand tot een nieuwe baan kan overbrugd worden door te pendelen of te verhuizen. Doordat regio's in Nederland worden gekenmerkt door lokale arbeidsmarkten die verschillen in vraag en aanbod van arbeid, hebben werkzoekenden een grotere kans een baan te vinden die aansluit bij de door hen gevolgde opleiding (qua niveau en/of -richting) indien hun zoekgebied groter is. Over het algemeen geldt dan ook dat degenen die zoeken naar vacatures op de landelijke arbeidsmarkt vaker een passende baan vinden dan degenen die uitsluitend op de lokale arbeidsmarkt zoeken. Aangezien niet iedereen bereid is voor een nieuwe baan over een grote afstand te pendelen of te verhuizen, kan de mate waarin werkzoekenden geografische mobiel zijn worden beschouwd als een belangrijke factor bij de keuze voor een baan.

In deze paragraaf wordt gekeken naar de rol die geografische mobiliteit speelt bij de inpassing van schoolverlaters in het arbeidsproces. Dit wordt gedaan voor school-

36. K. Asselberghs, R. Batenburg, F. Huijgen en M.C. de Witte (1998), De kwalitatieve structuur van de werkgelegenheid in Nederland: deel IV, OSA-voorstudie V44, Den Haag; M.H.J. Wolbers, M. de Graaf and W.C. Ultee (2001),'Trends in the occupational returns to educational credentials in the Dutch labor market: Changes in structures and in the association?', Acta Sociologica, Vol. 44, pp. 5-19.

37. M. Wolbers (2003), 'Job Mismatches and their Labour-Market Effects among Schoolleavers in Europe', European Sociological review, Vol. 19, pp. 249-266.

38. A. Kalleberg, B. Reskin and K. Hudson (2000), 'Bad jobs in America: Standard and nonstandard employment relations and job quality in the United States', American Sociological Review, Vol. 65, pp. 256-278. 
verlaters van het $\mathrm{VMBO}$, de $\mathrm{BOL}$ en $\mathrm{BBL}$ binnen het $\mathrm{MBO}$, en het $\mathrm{HBO}{ }^{39} \mathrm{Bij}$ een grote baandichtheid in de regio is de noodzaak om voor een passende baan te verhuizen of over een lange afstand te pendelen meestal veel kleiner. Er wordt per provincie de geografische mobiliteit van schoolverlaters in beeld gebracht en er wordt aangegeven welk deel van de schoolverlaters een (bij de opleiding) passende baan heeft gevonden. Hiertoe worden vier kenmerken van de banen van schoolverlaters bekeken: (1) een baan die past bij het behaalde opleidingsniveau (baan op niveau); (2) een baan die past bij de gevolgde opleidingsrichting (baan in de richting); (3) een vaste baan en (4) een voltijdbaan.

Figuur 5.1

Geografische mobiliteit van schoolverlaters bij hun intrede op de arbeidsmarkt per provincie, gemiddelde 1996-2001

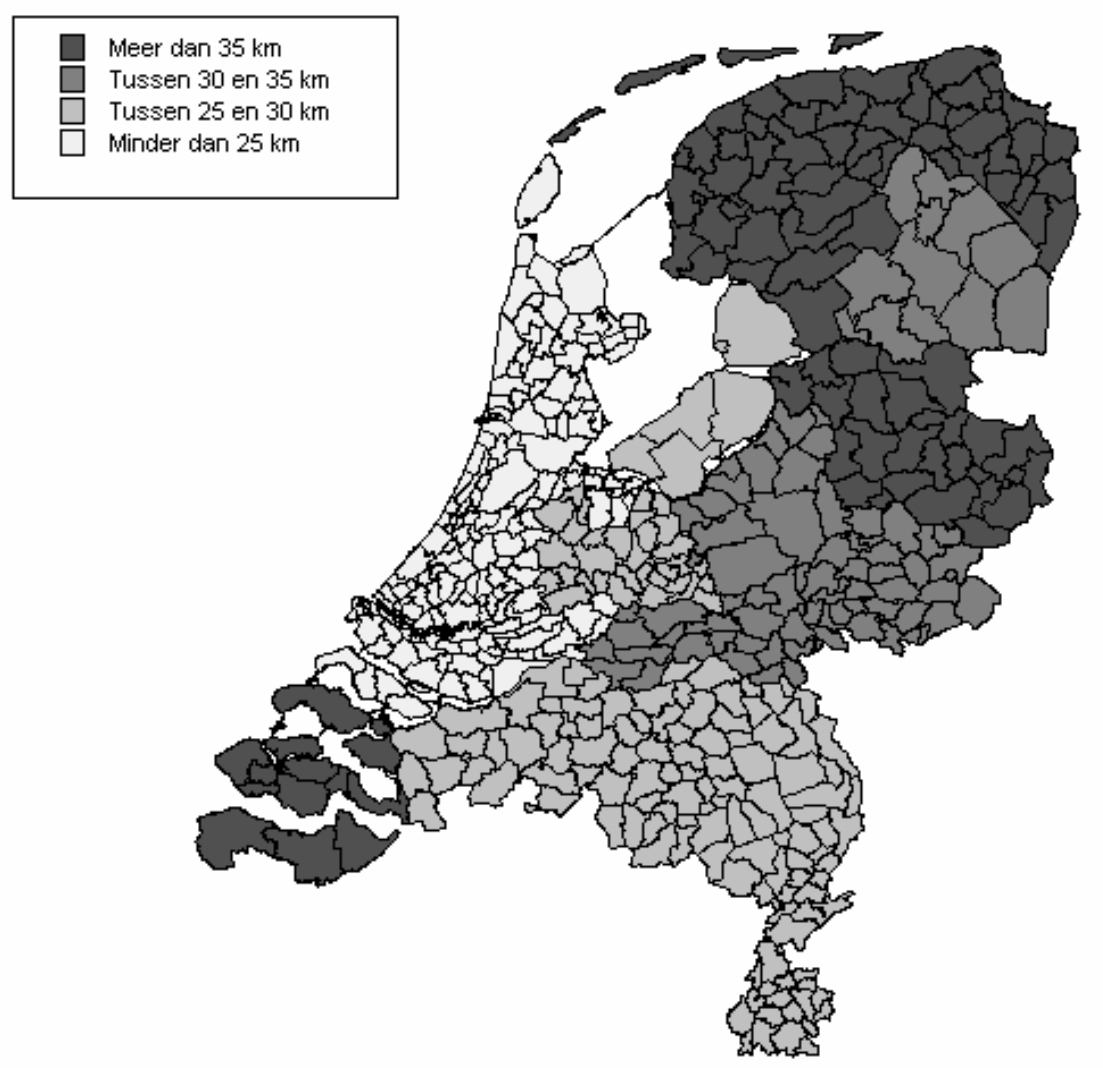

Bron: ROA/SIS

39. Schoolverlaters van het HAVO, VWO en het WO worden buiten beschouwing gelaten in dit hoofdstuk. Voor het HAVO en VWO geldt dat zeer weinig schoolverlaters instromen op de arbeidsmarkt. Hierdoor bevinden zich relatief weinig HAVO- en VWO-schoolverlaters in onze onderzoekspopulatie. De resultaten van de analyse voor deze groep schoolverlaters worden daarom niet voldoende betrouwbaar geacht. Voor het WO geldt dat universiteiten erg ongelijk zijn verdeeld over de verschillende provincies in Nederland. 
Voor de analyse zijn zes uitstroomcohorten samengenomen. Deze hebben betrekking op de meetjaren 1996 tot en met 2001 van de RUBS-enquête en de HBOMonitor. In de analyse is geselecteerd op gediplomeerde schoolverlaters tussen de 16 en de 30 jaar, die een voltijdse opleiding hebben gevolgd en anderhalf jaar na het verlaten van het onderwijs betaald werk hebben gevonden.

Verschillen tussen vraag en aanbod van arbeid op lokale arbeidsmarkten leiden ertoe dat werkzoekenden worden geconfronteerd met discrepanties op lokale arbeidsmarkten. Een deel van de schoolverlaters zal worden geconfronteerd met werkloosheid of een baan die minder goed aansluit bij de gevolgde opleiding. Figuur 5.1 geeft een overzicht van de regionale verschillen in geografische mobiliteit voor schoolverlaters in Nederland. Hiervoor is per provincie de gemiddelde geografische mobiliteit van schoolverlaters bepaald aan de hand van de afstand ${ }^{40}$ (in kilometers) tussen de gemeente waar de schoolverlater de opleiding heeft gevolgd, en de gemeente waar de schoolverlater een baan heeft gevonden. ${ }^{41}$ Het algemene beeld dat uit figuur 5.1 naar voren komt is dat de gemiddelde afstand tussen de gemeente waar men de opleiding heeft gevolgd en de werkgemeente het grootst is voor schoolverlaters in het noorden van Nederland en Zeeland. Daarna volgen schoolverlaters uit het oosten en zuiden van Nederland. Schoolverlaters uit het westen van Nederland zijn geografisch gezien het minst mobiel. Een belangrijke oorzaak voor deze verschillen is gelegen in de verschillen in werkgelegenheidsconcentratie tussen regio's. Ten gevolge van een grotere baandichtheid per vierkante kilometer hoeven schoolverlaters in het westen van het land gemiddeld genomen ook minder mobiel te zijn dan elders om een aantrekkelijke baan te vinden.

Tabel 5.1 laat zien dat de gemiddelde afstand tussen de gemeente waar de opleiding gevolgd is en de werkgemeente voor schoolverlaters in Groningen maar liefst 45 kilometer bedraagt. Dit betekent dat relatief veel schoolverlaters die in Groningen een opleiding gevolgd hebben buiten Groningen werkzaam zijn. Schoolverlaters uit de provincie Friesland zijn met 48 kilometer relatief het meest mobiel. Dat ligt anders voor schoolverlaters van de provincies Noord-Holland en Zuid-Holland. De gemiddelde afstand tussen de gemeente van de onderwijsinstelling van de schoolverlaters en de werkgemeente, is in deze provincies minder dan 20 kilometer. Ook hier is de baandichtheid van grote invloed op de mobiliteit van schoolverlaters.

Daarnaast worden in tabel 5.1 de regionale verschillen in de kans op een baan op niveau, een baan in de eigen richting, vast werk en een voltijd baan vermeld. Vast werk betekent hier dat schoolverlaters geen flexibele arbeidsrelatie hebben, dat wil zeggen niet werkzaam zijn als uitzendkracht, oproepkracht e.d. of werkzaam zijn in een tijdelijke aanstelling. Hieruit blijkt dat de kans op het vinden van een bij de opleiding passende baan duidelijk verschilt per provincie.

40. Hierbij wordt de afstand tussen twee gemeenten bepaald als de kortste goniometrische afstand.

41. De afstand tussen de gemeente waar de opleiding is gevolgd en de huidige werkgemeente verschilt van de afstand tussen woon- en werkgemeente. Het betreft dus de mobiliteit ten opzichte van de schoollocatie. 
Tabel 5.1

Geografische mobiliteit en vier kenmerken van de inpassing van schoolverlaters in het arbeidsproces per provincie, gemiddelde 1996-2001

\begin{tabular}{|c|c|c|c|c|c|}
\hline Provincie & $\begin{array}{l}\text { Mobiliteit } \\
\text { Km. }\end{array}$ & $\begin{array}{c}\text { Baan op } \\
\text { eigen niveau } \\
\%\end{array}$ & $\begin{array}{c}\text { Baan in eigen } \\
\text { vakrichting } \\
\%\end{array}$ & $\begin{array}{c}\text { Vast werk } \\
\text { \% }\end{array}$ & $\begin{array}{c}\text { Voltijdbaan } \\
\%\end{array}$ \\
\hline Groningen & 45 & 72 & 70 & 73 & 65 \\
\hline Friesland & 48 & 68 & 64 & 72 & 70 \\
\hline Drenthe & 32 & 64 & 57 & 81 & 69 \\
\hline Overijssel & 39 & 71 & 74 & 85 & 74 \\
\hline Gelderland & 31 & 74 & 74 & 80 & 69 \\
\hline Flevoland & 29 & 67 & 62 & 71 & 51 \\
\hline Utrecht & 26 & 74 & 73 & 83 & 75 \\
\hline Noord-Holland & 17 & 70 & 65 & 83 & 76 \\
\hline Zuid-Holland & 20 & 75 & 69 & 85 & 76 \\
\hline Zeeland & 37 & 64 & 72 & 86 & 72 \\
\hline Noord-Brabant & 26 & 72 & 74 & 86 & 79 \\
\hline Limburg & 29 & 69 & 69 & 81 & 75 \\
\hline Totaal & 28 & 71 & 70 & 83 & 75 \\
\hline
\end{tabular}

Bron: ROA/SIS

De inpassing van Gelderse schoolverlaters in het arbeidsproces is doorgaans redelijk. Gelderse schoolverlaters leggen gemiddeld een afstand van 31 kilometer af naar hun baan en zijn daarmee iets mobieler dan de gemiddelde schoolverlater (28 kilometer). De inpassing in het arbeidsproces verloopt voor de Gelderse schoolverlaters doorgaans beter dan gemiddeld wat betreft het niveau en de richting van de baan. Zo heeft $74 \%$ van de schoolverlaters een baan op niveau gevonden. Hetzelfde geldt voor een baan in de richting. Gelderse schoolverlaters hebben echter een relatief lage kans op het vinden van een vaste of een voltijdbaan.

\subsection{Effecten van een toenemende werkgelegenheid in Gelderland op de mobiliteit}

Werkgelegenheid in Gelderland betekent niet alleen werk voor mensen die in de provincie wonen, maar trekt ook werkenden uit naburige provincies. De reisafstand die mensen afleggen om op hun werk te komen is de laatste jaren aanzienlijk toegenomen. Als er in Gelderland meer banen ontstaan, dan betekent dit dus niet alleen extra werkgelegenheid voor de Gelderse bevolking, maar tot op zekere hoogte ook voor inwonenden van andere provincies. Naast deze pendelstromen, zijn er ook mensen die verhuizen omdat ze een nieuwe baan hebben gekregen. Een werkgelegenheidstoename in Gelderland zal daarom ook leiden tot een toename van de bevolking.

In deze paragraaf wordt ingegaan op deze spill-over effecten van de werkgelegenheidsgroei in Gelderland. Allereerst wordt een beeld gegeven van de ontwikkeling van de pendel van andere provincies naar Gelderland van 1991 tot 2001. Daarna wordt ingegaan op de effecten die een groeiende werkgelegenheid heeft 
voor de pendel, de omvang van de bevolking en de participatiegraad. Ten slotte zal op basis van de werkgelegenheidsprognoses voor de provincie Gelderland een raming worden gegeven van de het deel van deze werkgelegenheidsgroei dat door werkenden van buiten de provincie zal worden vervuld.

\section{Herkomst van werkenden in Gelderland}

In figuur 5.2 wordt getoond hoe de reisafstand van werkenden in de provincie zich de tussen 1991 en 2001 heeft ontwikkeld. De ontwikkelingen in Gelderland lopen in grote lijnen parallel met de landelijke ontwikkelingen. In vergelijking met het Nederland blijken mensen in Gelderland echter gemiddeld iets dichter bij hun werk te wonen. Conform de landelijke ontwikkelingen is het percentage werkenden dat hoogstens 10 kilometer van het werk woont afgenomen van 63 naar 55\%. Substantiële stijgingen doen zich voor bij het aantal werkenden dat 15 tot 50 kilometer van het werk woont.

Figuur 5.2

Verdeling van de woon-werk-afstand van mensen die in Gelderland werken in 1991 en 2001

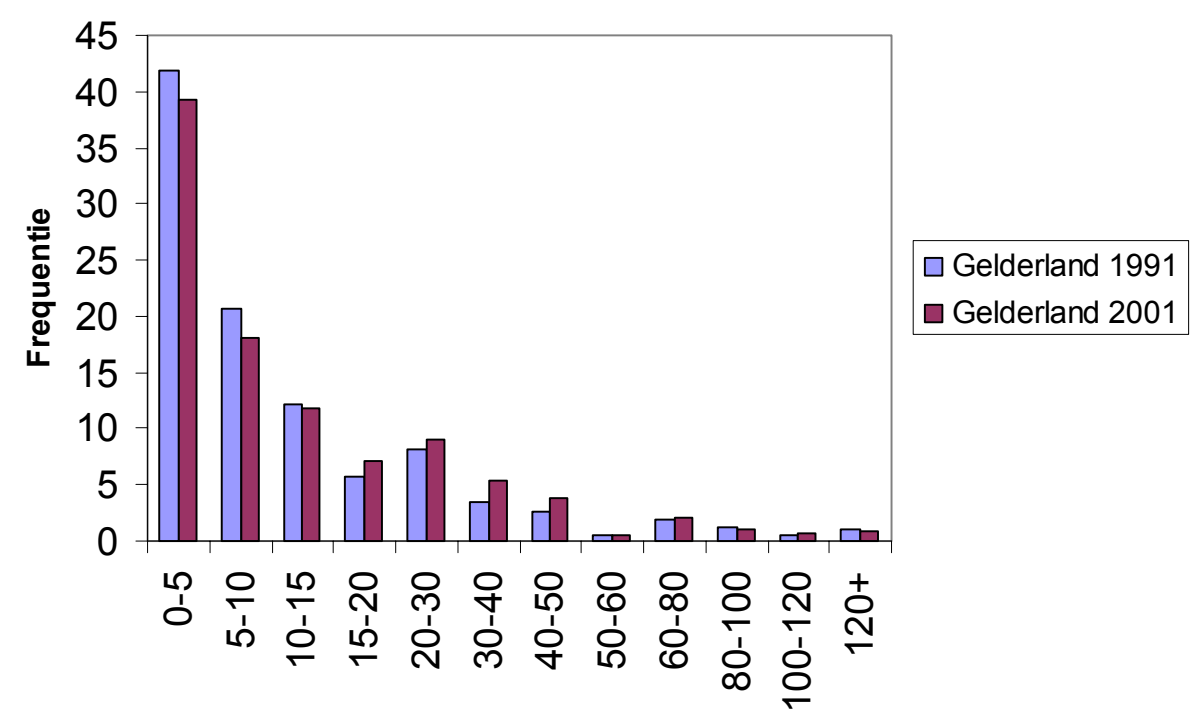

Reisafstand in kilometers

Bron: CBS/OVG

Als gevolg van de toegenomen reisafstanden zijn ook de reistijden toegenomen. In 1991 woonden de werkenden in Gelderland gemiddeld 13,2 kilometer van hun werk. De reis duurde gemiddeld 14,9 minuten. In 2001 is de gemiddelde reisafstand gestegen tot 20,1 kilometer en duurt deze reis 21,6 minuten. Deze langere reistijden zijn vrijwel volledig het gevolg van de langere afstanden. Afname van de gemiddelde snelheid - als gevolg van de toegenomen congestie - speelt slechts een zeer geringe rol. De langere reistijden betekenen wel dat inwoners in Gelderland steeds vroeger naar hun werk gaan In 1991 was 22,9\% van de werkenden voor 7 uur op 
pad. Inmiddels is dat $27,7 \%$. Op grond van deze tendens zou verwacht mogen worden dat steeds meer werkenden van buiten de provincie in Gelderland komen werken. Tabel 5.2 laat echter zien dat deze provinciegrensoverschrijdende pendel nauwelijks is toegenomen in de periode 1991-2001.

Tabel 5.2

Herkomst en bestemming van werkenden in Gelderland in 1991 en 2001

\begin{tabular}{|c|c|c|c|c|c|c|c|c|c|c|}
\hline \multirow[t]{2}{*}{ Bestemming } & \multicolumn{2}{|c|}{ Veluwe } & \multicolumn{2}{|c|}{ Achterhoek } & \multicolumn{2}{|c|}{$\begin{array}{l}\text { Arnhem/ } \\
\text { Nijmegen }\end{array}$} & \multicolumn{2}{|c|}{$\begin{array}{l}\text { Zuidwest- } \\
\text { Gelderland }\end{array}$} & \multicolumn{2}{|c|}{$\begin{array}{c}\text { Gelderland } \\
\text { totaal }\end{array}$} \\
\hline & 1991 & 2001 & 1991 & 2001 & 1991 & 2001 & 1991 & 2001 & 1991 & 2001 \\
\hline \multicolumn{11}{|l|}{ Herkomst } \\
\hline Groningen & & 0,2 & & 0,1 & & & & & & 0,1 \\
\hline Friesland & & 0,1 & 0,4 & 0,2 & 0,1 & 0,1 & & & 0,1 & 0,1 \\
\hline Drenthe & 0,5 & 0,1 & & 0,6 & & 0,1 & & & 0,2 & 0,2 \\
\hline Overijssel & 5,3 & 7,2 & 3,8 & 5,3 & 1,0 & 1,3 & & 0,7 & 2,9 & 4,0 \\
\hline Flevoland & 0,6 & 1,7 & & & & 0,1 & & & 0,2 & 0,6 \\
\hline Gelderland & 80,6 & 81,5 & 94,1 & 92,0 & 90,1 & 90,1 & 78,8 & 80,5 & 86,8 & 86,4 \\
\hline Utrecht & 8,8 & 6,4 & 0,2 & 0,3 & 0,6 & 1,0 & 6,8 & 3,8 & 3,8 & 3,0 \\
\hline Noord-Holland & 1,0 & 0,8 & 0,9 & 0,8 & 0,5 & 0,6 & 2,0 & 1,0 & 0,9 & 0,8 \\
\hline Zuid-Holland & 1,8 & 0,8 & 0,6 & 0,2 & 0,3 & 0,4 & 4,2 & 4,7 & 1,2 & 1,0 \\
\hline Zeeland & 0,1 & & & & & & & & 0,0 & \\
\hline Noord-Brabant & 1,2 & 0,7 & & 0,2 & 5,5 & 4,5 & 8,2 & 9,2 & 3,2 & 2,9 \\
\hline Limburg & 0,1 & 0,3 & & 0,4 & 1,8 & 1,7 & & 0,1 & 0,7 & 0,8 \\
\hline Totaal & 100 & 100 & 100 & 100 & 100 & 100 & 100 & 100 & 100 & 100 \\
\hline \multicolumn{11}{|c|}{ Gelderland naar COROP-gebied } \\
\hline Veluwe & 74,1 & 72,6 & 2,4 & 1,9 & 2,8 & 1,8 & & 0,7 & 26,3 & 26,4 \\
\hline Achterhoek & 1,6 & 2,4 & 90,6 & 84,8 & 4,0 & 5,2 & & 0,2 & 20,3 & 17,9 \\
\hline $\begin{array}{l}\text { Arnhem/Nijmegen } \\
\text { Zuidwest- }\end{array}$ & 4,9 & 5,7 & 4,1 & 5,1 & 82,3 & 81,9 & 2,7 & 5,9 & 33,8 & 33,5 \\
\hline Gelderland & 0,6 & 0,8 & & 0,3 & 1,1 & 1,3 & 77,3 & 73,7 & 7,3 & 8,7 \\
\hline
\end{tabular}

* Noot: een ontbrekend cijfer betekent dat er geen of heel weinig pendel is waargenomen. Bron: CBS/OVG

De tabel geeft een overzicht van de provincies waar werkenden in Gelderland wonen. Het percentage mensen van buiten Gelderland dat niet in Gelderland werkt is slechts toegenomen van 13,2 naar $13,6 \%$. In de Veluwe en Zuidwest-Gelderland is het aantal werkenden van buiten de provincie afgenomen. Als de mobiliteit wordt uitgesplitst naar de vier COROP-regio's in de provincie dan blijkt wel de pendel van buiten elke COROP-regio aanzienlijk te zijn toegenomen.

De oorzaak van dit opmerkelijk patroon is dat mensen in steeds sterkere mate naar het westen gaan om te werken en dus in het oosten of noordoosten van hun werk wonen. In de Veluwe daalt het aantal werkenden uit Utrecht van 8,8 naar $6,4 \%$ en stijgt het aantal werkenden uit Overijssel van 5,3 naar $7,2 \%$. Ook de pendel vanuit 
Arnhem/Nijmegen neemt toe. In de Achterhoek stijgt het aantal werkenden vanuit de provincie Overijssel. De pendel vanuit de Veluwe daalt enigszins. In Arnhem/Nijmegen stijgt de pendel vanuit de Achterhoek van 4,0 naar 5,2\%, maar daalt het percentage werkenden dat uit de Veluwe of Noord-Brabant komt. In ZuidwestGelderland daalt het percentage werkenden uit de provincie Utrecht van 6,8 naar $3,8 \%$ en stijgt de toestroom vanuit Arnhem/Nijmegen van 2,7 naar 5,9\%.

Tabel 5.3 zet de in- en uitgaande pendel per COROP-gebied tegenover elkaar. Hieruit blijkt inderdaad dat in Gelderland niet alleen het aantal werkenden dat van buiten een COROP-gebied komt werken is gestegen, maar dat ook steeds meer inwoners uit Gelderland buiten hun COROP-gebied gaan werken. In 1991 kenden de Achterhoek en Zuidwest-Gelderland een grotere uitgaande dan inkomende pendel. Inmiddels is ook in de regio Arnhem/Nijmegen de uitgaande pendel groter dan de inkomende pendel. In 1993 schetste het Bureau Economisch Onderzoek van de provincie Gelderland dat in Arnhem en Nijmegen de uitgaande pendel erg groot was, en dat het vanuit het oogpunt van mobiliteitsbeleid wenselijk zou zijn als meer mensen in dit gebied gestimuleerd worden in de eigen regio te werken. ${ }^{42}$ De tabel maakt echter duidelijk dat deze pendel blijft toenemen. Omdat de ontwikkelingen duidelijk passen in de landelijke trend van toenemende mobiliteit met een steeds grotere stroom werkenden richting de Randstad, valt niet te verwachten dat dit tij makkelijk te keren is.

Tabel 5.3

Inkomende en uitgaande pendelstromen per Gelders COROP-gebied in 1991 en 2001

\begin{tabular}{lrrrr} 
& \multicolumn{3}{c}{ Inkomende pendel } & \multicolumn{3}{c}{ Uitgaande pendel } \\
COROP-gebied & 1991 & 2001 & 1991 & 2001 \\
& & & & \\
\hline & 25,9 & 27,4 & 23,6 & 24,2 \\
Veluwe & 9,4 & 15,2 & 15,5 & 23,7 \\
Achterhoek & 17,7 & 18,1 & 13,6 & 21,3 \\
Arnhem/Nijmegen & 22,7 & 26,3 & 35,7 & 37,7 \\
Zuidwest-Gelderland & & & &
\end{tabular}

\section{Bron: CBS/OVG}

Deze verschuiving hangt waarschijnlijk samen met de werkgelegenheidsontwikkeling in de Randstad. Met name hoger opgeleide mannen werken steeds vaker in de Randstad. Dit betekent niet alleen dat mensen die in Gelderland wonen vaker werk vinden in de Randstad, maar ook dat de huizenprijzen in die regio stijgen in vergelijking met naburige regio's. Huizen worden daardoor duurder naarmate ze meer naar het westen liggen. Het wordt dus aantrekkelijker om ten oosten van het werk te gaan wonen, ook voor mensen die niet in de Randstad wonen.

Bij mannen met een HBO- of WO-achtergrond blijkt in 2001 maar liefst 27,5\% van de werkenden buiten de provincie te wonen. In 1991 was dit percentage nog maar $21,8 \%$. Deze mobiliteit neemt dus zeer snel toe. Met name onder hoger opgeleide

42. Zie BEO (1993), Tussen Arnhem \& Nijmegen; Een analyse van de Overbetuwse woonwerkbalans, provincie Gelderland, Arnhem. 
mannen in Zuidwest-Gelderland wordt de Randstad steeds duidelijker de belangrijkste regio voor werkgelegenheid. Van de hoger opgeleiden die in Zuidwest Gelderland wonen werkte in $199127,5 \%$ buiten de provincie. In 2001 betrof dit reeds $49,3 \%$. Voor hoogopgeleide vrouwen uit dit deel van de provincie steeg de grensoverschrijdende mobiliteit van 14,0 naar $35,2 \%$.

De grootste leverancier van werkenden in Gelderland is nu de provincie Overijssel. Vanuit Overijssel en Zuid-Holland komen meer mensen werken in Gelderland dan dat er werkenden uit Gelderland naar die provincies gaan. Voor Utrecht en NoordHolland ligt die verhouding omgekeerd. Per saldo gaat hier een grotere stroom van mensen die in Gelderland wonen, werken in deze provincies. Bij Noord-Brabant en Limburg is de balans ongeveer in evenwicht. Opnieuw blijken mensen die van buiten de provincie in Gelderland komen werken vooral in Zuidwest-Gelderland te werken.

Tabel 5.4

Bijdrage in de Gelderse werkgelegenheid van werkenden uit andere provincies naar opleidingsniveau en geslacht in 1991 en 2001

\begin{tabular}{lll} 
Opleidingsniveau & 1991 & 2001 \\
\hline
\end{tabular}

$\begin{array}{lrr}\text { Mannen } & & \\ \text { Basisschool } & 11,9 & 9,7 \\ \text { VMBO } & 13,6 & 14,6 \\ \text { MBO } & 17,4 & 16,0 \\ \text { HBO of WO } & 13,9 & 20,6 \\ \text { Totaal } & 15,2 & 16,4 \\ & & \\ \text { Vrouwen } & & \\ \text { Basisschool } & - & 3,6 \\ \text { VMBO } & 3,0 & 6,5 \\ \text { MBO } & 6,6 & 8,6 \\ \text { HBO of WO } & 31,8 & 12,5 \\ \text { Totaal } & 9,1 & 8,8\end{array}$

-: geen betrouwbare gegevens beschikbaar

Bron: CBS/OVG

In tabel 5.4 wordt de herkomst van werkenden in Gelderland uitgesplitst naar geslacht en opleidingsniveau. Werkende mannen komen vaker van buiten de provincie dan vrouwen en de mobiliteit stijgt met het opleidingsniveau. Vanwege de tegengestelde effecten van een afnemende mobiliteit vanuit het westen en een toenemende mobiliteit uit het oosten is er geen eenduidig patroon in de ontwikkeling van 1991-2001. Met name de afname van de instroom van hoogopgeleide vrouwen van 31,8 naar $12,5 \%$ is opmerkelijk. Het lijkt er op dat vrouwen die in Utrecht wonen steeds vaker werk vinden in Utrecht en andere delen van de Randstad en daardoor minder vaak in Gelderland gaan werken.

\section{Gevolgen van een toename van de werkgelegenheid}

Om zicht te krijgen op de effecten van het werkgelegenheidsbeleid van de provincie is het belangrijk om een beeld te hebben van de verschuivende pendelstromen tussen de provincies. Daarbij rijst ook de vraag in hoeverre een toename van de 
werkgelegenheid in een gemeente leidt tot een toename van de forensenstroom uit andere gemeenten. Nieuwe werkgelegenheid kan ook betekenen dat mensen uit andere regio's werk krijgen en vervolgens verhuizen naar een plaats in de buurt van dit nieuwe werk.

Op basis van de vergelijking tussen 1991 en 2001 is geanalyseerd welke gevolgen een toename in de werkgelegenheid heeft voor de mobiliteit. Tabel 5.5 geeft hiervan een beeld. De werkenden in een bepaalde gemeente, wonen doorgaans voor een aanzienlijk deel in diezelfde gemeente of in een naburige gemeente. Voor de duidelijkheid geven we de plaats waar de werkgelegenheid stijgt aan als de werkgemeente. De plaatsen waar werkenden wonen noemen we de woongemeenten. Voor de werkenden die wonen in de gemeente waar ze werken is de werkgemeente dus ook de woongemeente. Als de werkgelegenheid in een werkgemeente toeneemt, moet het aantal mensen uit de eigen gemeente of uit één van de andere woongemeenten toenemen. Uit de eerste rij van de tabel blijkt dat als de werkgelegenheid in een gemeente met $1 \%$ stijgt, de hoeveelheid werkenden uit dezelfde gemeente naar verwachting met $0,96 \%$ en dus bijna ook $1 \%$ stijgt. De stroom pendelaars uit andere woongemeenten neemt slechts met $0,36 \%$ toe.

Tabel 5.5

Effecten van een toenemende werkgelegenheid op de participatiegraad, bevolkingsomvang en pendel

\begin{tabular}{|c|c|c|}
\hline \multicolumn{3}{|l|}{ Alle gemeenten } \\
\hline & Eigen gemeente & Pendelgemeenten \\
\hline Totaal & 0,96 & 0,36 \\
\hline Toename werkenden & 0,59 & 0,06 \\
\hline $\begin{array}{l}\text { w.o. toename participatie } \\
\text { toename bevolking }\end{array}$ & $\begin{array}{l}0,18 \\
0,36\end{array}$ & 0,04 \\
\hline Toename pendel & 0,45 & 0,31 \\
\hline \multicolumn{3}{|c|}{ Grote gemeenten (minstens 80.000 inwoners) } \\
\hline & Eigen gemeente & Pendelgemeenten \\
\hline Totaal & 0,88 & 0,80 \\
\hline Toename werkenden & 1,01 & 0,09 \\
\hline W.o. toename participatie & 0,20 & 0,06 \\
\hline toename bevolking & 0,86 & 0,03 \\
\hline Toename pendel & 0,41 & 0,68 \\
\hline \multicolumn{3}{|c|}{ Kleine gemeenten (hoogstens 15.000 inwoners) } \\
\hline & Eigen gemeente & Pendelgemeenten \\
\hline Totaal & 0,99 & 0,14 \\
\hline Toename werkenden & 0,38 & 0,05 \\
\hline w.o. toename participatie & 0,08 & 0,05 \\
\hline toename bevolking & 0,23 & \\
\hline Toename pendel & 0,41 & 0,14 \\
\hline \multicolumn{3}{|l|}{ Gelderse gemeenten } \\
\hline & Eigen gemeente & Pendelgemeenten \\
\hline Totaal & 0,89 & 0,14 \\
\hline Toename werkenden & 0,24 & 0,23 \\
\hline w.o. toename participatie & & 0,19 \\
\hline toename bevolking & 0,33 & 0,02 \\
\hline Toename pendel & 0,49 & 0,15 \\
\hline
\end{tabular}

-: geen betrouwbare gegevens beschikbaar

Bron: ROA 
Deze toename van het aantal werkenden uit verschillende gemeenten kan gerealiseerd worden door een toename van het aantal werkenden in die gemeente of door een toename van het aantal werkenden in een woongemeente dat in de betreffende werkgemeente gaat werken. In de tabel wordt de eerste mogelijkheid weergegeven in de regel 'Toename werkenden'. Het blijkt dat in het algemeen in de eigen gemeente een behoorlijke toename van het aantal werkenden is, maar dat dit effect in andere woongemeenten vrijwel nihil is. Deze toename van het aantal werkenden kan worden gerealiseerd doordat meer mensen in een gemeente gaan wonen (omdat er meer werk is), of door een toename van de participatiegraad. Uit de tabel blijkt dat gemiddeld genomen de toename van de bevolking als reactie op een groeiende werkgelegenheid ongeveer twee keer zo groot is als het participatiegraadeffect.

Daarnaast kan een werkgemeente met een groeiende werkgelegenheid een groter aandeel van de werkende beroepsbevolking uit de verschillende woongemeenten aantrekken. Dit wordt aangeduid als toename pendel (ook als deze mensen uit de eigen gemeente komen, het betreft dan mensen die voorheen buiten de eigen gemeente werkten). Uit het eerste deel van de tabel blijkt dat - bij een gemiddelde gemeente - als de werkgelegenheid groeit, zowel het aantal mensen dat in de eigen gemeente gaat werken als het aandeel van de werkenden uit de buurgemeenten dat naar deze plaats toekomt toeneemt. Beide effecten verschillen niet veel van elkaar.

Het tweede deel van tabel 5.5 laat de werkgelegenheidseffecten zien voor alleen grotere werkgemeenten van minstens 80.000 inwoners. Bij deze grote werkgemeenten blijkt een veel duidelijkere uitstraling uit te gaan naar buurgemeenten. Dit effect bestaat echter vrijwel alleen uit een toename van de pendel naar de betreffende werkgemeente en nauwelijks uit een toename van de bevolking of participatie. De toename van de werkzame beroepsbevolking in de eigen gemeente als gevolg van een werkgelegenheidstoename komt, in tegenstelling tot het beeld bij alle gemeenten, vrijwel volledig voor rekening van een toename van het aantal inwoners. Werkgelegenheidsgroei in grote gemeenten leidt er dus toe dat veel nieuwe mensen zich hier vestigen, maar heeft maar een kleine invloed op de participatiegraad.

Het derde deel geeft vergelijkbare resultaten voor kleine gemeenten (minder dan 15.000 inwoners) als voor alle gemeenten gezamenlijk. Werkgelegenheidstoenames in kleine gemeenten hebben vrijwel alleen effect voor de eigen gemeente. Ten slotte is in het vierde deel van de tabel een aparte schatting voor Gelderland gemaakt. Door de kleinere omvang van het aantal waarnemingen zijn deze schattingen minder precies, maar het lijkt erop dat het beeld voor Gelderland niet sterk afwijkt van het landelijke beeld. Alleen de invloed van toenemende werkgelegenheid op de participatiegraad in buurgemeenten, lijkt in Gelderland groter te zijn dan in de rest van het land. 
Verwachte werkgelegenheidstoename 2004-2008

Op basis van de werkgelegenheidsprognoses uit de Regionaal Economische Databank 2004 van Bureau Economisch Onderzoek Provincie Gelderland is een prognose gemaakt van de 'spill-over' effecten die de verwachte werkgelegenheidsgroei in Gelderland in de periode tot 2008 zal hebben. Hierbij zijn de effecten per gemeente afzonderlijk bepaald en is rekening gehouden met de verschillen in opleidingsniveau en geslacht.

Tabel 5.6 laat zien dat ongeveer $15 \%$ van de werkgelegenheidstoename naar verwachting vervuld zal worden door werkenden uit naburige provincies. Het grootste deel van deze nieuwe werkenden van buiten Gelderland komt uit Utrecht $(4,3 \%)$, gevolgd door Overijssel $(3,4 \%)$ en Noord-Brabant $(3,2 \%)$.

Tabel 5.6

Percentage werkgelegenheidstoename door pendel tot 2008, naar provincie van herkomst

Provincie

Groningen

Friesland

0,0

Drenthe

0,2

Overijssel

Flevoland

Gelderland

Utrecht

Noord-Holland

Zuid-Holland

Zeeland

Noord-Brabant
Limburg

Totaal

Bron: CBS/OVG

Tabel 5.7

Percentage werkgelegenheidstoename door verhuizingen tot 2008, naar opleidingsniveau

Opleidingsniveau

Basisschool

VMBO

MBO

$\mathrm{HBO}$ of WO

Bron: CBS/OVG

Daarnaast is de verwachting dat bijna $10 \%$ van de werkgelegenheidstoename vervuld zal worden door mensen die naar Gelderland verhuizen. Uiteraard is het totaal aantal verhuizingen vanwege het vinden van werk veel groter dan dit cijfer, maar het gaat hier alleen om het netto aantal extra verhuizingen als gevolg van de werkgelegenheidsgroei. Tabel 5.7 laat zien dat deze instroom van mensen die naar 
Gelderland verhuizen vanwege de werkgelegenheidstoename relatief groot is onder hoger opgeleiden.

Tabel 5.8 splitst deze cijfers uit naar de vier COROP-gebieden in Gelderland. Met name in de Veluwe en Zuidwest-Gelderland trekt de werkgelegenheidsgroei in de provincie relatief veel pendelaars uit andere provincies aan. De toename van de bevolking is in Zuidwest-Gelderland iets lager dan in de drie andere gebieden.

Tabel 5.8

Verwachte toename van de pendel van buiten Gelderland en de toename van de bevolking in Gelderland tot 2008, naar COROP-gebied

COROP-gebied Pendel van buiten Toename bevolking
Gelderland

$\begin{array}{lrr}\text { Veluwe } & 17,6 & 10,2 \\ \text { Achterhoek } & 6,5 & 10,1 \\ \text { Arnhem/Nijmegen } & 11,1 & 11,6 \\ \text { Zuidwest-Gelderland } & 21,0 & 7,2\end{array}$

Bron: CBS/OVG

\subsection{Geografische mobiliteit en knelpunten in de personeelsvoorziening in Gelderland}

Naast het effect van geografische mobiliteit op de aanpassingen die schoolverlaters bereid zijn te accepteren om een baan te vinden, heeft geografische mobiliteit een effect op de verwachte arbeidsmarktsituatie in Gelderland en Nederland. Hiervoor kan gekeken worden naar de vereiste verandering in de inkomende pendelstromen of de instroom van schoolverlaters om toekomstige knelpunten in de personeelsvoorziening voor werkgevers op te lossen. Door mensen van buiten Gelderland aan te trekken voor specifieke functies kunnen de knelpunten in de personeelsvoorziening voor werkgevers verkleind worden. Anderzijds kunnen eventuele overschotten voor bepaalde beroepen in Gelderland worden gereduceerd als de inkomende pendelstroom afneemt. Daarnaast kan een grotere instroom van schoolverlaters en afgestudeerden op de Gelderse arbeidsmarkt de personeelsschaarste voor Gelderse werkgevers verlichten ten koste van werkgevers in andere provincies, of kunnen schoolverlaters hun perspectief op de arbeidsmarkt verbeteren door zich aan te bieden in andere provincies waar de schaarste aan personeel groter is. Hieronder worden de verwachte toekomstige tekorten per beroepsklasse (zie paragraaf 4.3 ) in verband gebracht met de inkomende pendelstroom (op basis van gemiddelde pendelstromen 2000-2001) en de instroom van schoolverlaters en afgestudeerden (prognose tot 2008) op de Gelderse arbeidsmarkt.

Tabel 5.9 laat zien dat het aantal inkomende pendelaars voor de Pedagogische beroepen in totaliteit met $172 \%$ moet toenemen om de toekomstige knelpunten in de personeelsvoorziening in deze beroepsklasse op de Gelderse arbeidsmarkt op te lossen. Hetzelfde wordt bereikt indien de instroom van schoolverlaters met $169 \%$ 
toeneemt. Hieruit kan geconcludeerd worden dat de rekruteringsproblemen voor Gelderse onderwijsinstellingen slechts in zeer beperkte mate verlicht kunnen worden door veranderingen in het arbeidsaanbod te bewerkstelligen, temeer omdat voor de Pedagogische beroepen de knelpunten in de rest van Nederland nog groter zijn (zie paragraaf 4.3). Ook voor de Openbare orde- en veiligheidsberoepen zijn de knelpunten in de rest van Nederland groter dan in Gelderland, waardoor een eventuele toename van de mobiliteit juist in de andere (voor Gelderland verkeerde) richting zou kunnen werken. Hierdoor zouden de knelpunten in de personeelsvoorziening voor werkgevers op de Gelderse arbeidsmarkt juist vergroot worden.

Tabel 5.9

Vereiste verandering van regionaal arbeidsaanbod om rekruteringsproblemen voor Gelderse werkgevers op te lossen, als percentage van de verwachte tekorten en overschotten tot 2008 per beroepsklasse

\begin{tabular}{ccc}
\hline Beroepsklasse & $\begin{array}{c}\text { Vereiste verandering in regionaal arbeidsaanbod } \\
\text { Inkomende } \\
\text { pendelaars } \%\end{array}$ & $\begin{array}{c}\text { Instroom van } \\
\text { schoolverlaters } \%\end{array}$ \\
\hline
\end{tabular}

Pedagogische beroepen

Culturele beroepen

Agrarische beroepen

Technische en industrieberoepen

Transportberoepen

Medische en paramedische beroepen

Economisch-administratieve beroepen

Informaticaberoepen

Sociaal-culturele beroepen

Verzorgende en dienstverlenende beroepen

Openbare orde- en veiligheidsberoepen

$\begin{array}{rr}172 & 169 \\ 40 & 22 \\ -16 & -3 \\ 1 & 1 \\ - & - \\ - & - \\ -48 & -26 \\ 41 & 42 \\ -14 & -9 \\ 29 & 10 \\ 58 & 123\end{array}$

- : geen betrouwbare gegevens beschikbaar

Bron: ROA

Voor de Technische en industrieberoepen geldt dat een stijging in het arbeidsaanbod van inkomende pendelaars of schoolverlaters van $1 \%$ leidt tot het oplossen van de knelpunten in de personeelsvoorziening in Gelderland. Dit is een aantrekkelijke optie omdat de knelpunten in de personeelsvoorziening in de rest van Nederland kleiner zijn dan in Gelderland (zie hoofdstuk 4). Bovendien is er slechts een relatief kleine verandering nodig van het regionale arbeidsaanbod in Gelderland. Voor de Culturele beroepen is dit moeilijker, omdat de vereiste verandering in het regionale arbeidsaanbod groter is. Bovendien zijn er voor deze beroepen ook knelpunten in de personeelsvoorziening in de rest van Nederland. Voor de Sociaal-culturele beroepen is juist een daling in het Gelderse arbeidsaanbod vereist om op dit arbeidsmarktsegment evenwicht op de Gelderse arbeidsmarkt te bereiken, namelijk van $14 \%$ voor de inkomende pendelaars en $9 \%$ voor de instroom van schoolverlaters op de arbeidsmarkt. Dit is eveneens een aantrekkelijke optie, omdat de knelpunten voor deze beroepen in de rest van Nederland groter zijn. Hetzelfde speelt, in mindere mate, ook voor de Economisch-administratieve beroepen. 



\title{
Bijlage A \\ Verklarende woordenlijst ${ }^{43}$
}

\begin{abstract}
Arbeidsmarktinstroom van schoolverlaters
Het aanbod van nieuwe arbeidskrachten op de arbeidsmarkt, zoals deze is bepaald door de verwachte uitstroom van schoolverlaters uit het initiële dagonderwijs inclusief de schoolverlaters van de beroepsbegeleidende leerweg (het voormalige leerlingwezen) -, de schoolverlaters van het deeltijdonderwijs, het niet-reguliere voltijdonderwijs en de beroepsgerichte volwasseneneducatie. Voor deze groep nieuwe arbeidskrachten wordt in dit rapport soms ook de alternatieve term 'nieuwkomers op de arbeidsmarkt' gebruikt.
\end{abstract}

\section{Arbeidsmarktkrapte}

Het begrip arbeidsmarktkrapte dat in deze rapportage gehanteerd wordt, is gedefinieerd als de verhouding tussen het aantal openstaande vacatures en het aantal niet-werkende werkzoekenden in bemiddelingsfase 1 per arbeidsmarktsegment. Wanneer de indicator voor de arbeidsmarktkrapte kleiner is dan één, is er sprake van een aanbodoverschot op het betreffende segment. Wanneer de indicator voor de arbeidsmarktkrapte groter is dan één, is er sprake van een tekort aan nietwerkende werkzoekenden in het betreffende segment. Dit tekort kan twee oorzaken hebben: wanneer het aanbod getalsmatig tekortschiet is er sprake van een kwantitatief probleem. Wanneer het probleem vooral gelegen is in het feit dat het aantal nietwerkende werkzoekenden in fase 1 als percentage van het totaal aantal nietwerkende werkzoekenden laag is, is dit tekort vooral een kwalitatief aansluitingsprobleem.

\section{Baanopeningen}

De baanopeningen representeren de totale vraag naar nieuwkomers op de arbeidsmarkt, zoals deze is bepaald door de werkgelegenheidsgroei (positieve uitbreidingsvraag) en de (netto) vervangingsvraag. Bij het vaststellen van het aantal baanopeningen wordt ermee rekening gehouden dat het aannemen van schoolverlaters door bedrijven en instellingen ('de vraag naar schoolverlaters') op nagenoeg hetzelfde niveau blijft ondanks een eventuele werkgelegenheidskrimp vanwege de extra uitstroom van ouderen. Een werkgelegenheidskrimp voor een opleidingstype of beroepsgroep gaat derhalve nauwelijks ten koste van het aantal baanopeningen in een opleidingstype of beroepsgroep.

\section{Bedrijfssector}

Alle voorkomende bedrijven zijn ingedeeld in een aantal clusters. De in deze rapportage gepresenteerde informatie is - met uitzondering van de totale werkgelegenheid - verbijzonderd naar 13 bedrijfssectoren. Deze komen overeen met de

43. De definities van begrippen sluiten zoveel aan bij de definities die in de landelijke rapportage worden gebruikt. Zie voor een verdere toelichting op de gehanteerde definities F. Cörvers et al. (2004), Methodiek arbeidsmarktprognoses en -indicatoren 2003-2008, ROA-W-2004/2, Maastricht. 
door het CPB gehanteerde bedrijfssectorindeling (zie Bijlage B). Verder wordt er in RAMING Digitaal waar mogelijk onderscheid gemaakt tussen 34 bedrijfssectoren.

\section{Bemiddelingsfase}

Het begrip bemiddelingsfase dat in deze rapportage wordt gehanteerd, is gebaseerd op de indeling van werkzoekenden zoals die door het Centrum voor Werk en Inkomen (CWI) wordt gehanteerd. Een hogere bemiddelingsfase impliceert een grotere afstand tot de arbeidsmarkt:

- $\quad$ Fase 1: De werkzoekende voor wie arbeidsmarktinstrumenten beschikbaar zijn gericht op directe bemiddeling of terugkeer naar de arbeidsmarkt.

- $\quad$ Fase 2: De werkzoekende voor wie arbeidsmarktinstrumenten beschikbaar zijn gericht op een zodanige verbetering van de kans op werk, dat hij/zij binnen een tijdsbestek van maximaal een jaar als werkzoekende bemiddelbaar is op de arbeidsmarkt.

- $\quad$ Fase 3: De werkzoekende voor wie arbeidsmarktinstrumenten beschikbaar zijn gericht op een zodanige verbetering van de kans op werk, dat hij/zij binnen een tijdsbestek van meer dan een jaar als werkzoekende bemiddelbaar is op de arbeidsmarkt.

- Fase 4: De werkzoekende die tengevolge van zware persoonlijke arbeidsbelemmeringen is aangewezen op hulp en zorg die gericht is op een zodanige verbetering van zijn/haar eigen positie dat eerst op termijn arbeidsmarktinstrumenten inzetbaar zijn gericht op de verbetering van de kans op werk.

\section{Beroepsgroep, Beroepsklasse, Beroepssegment}

Alle voorkomende beroepen zijn ingedeeld in een aantal clusters. In deze rapportage en de bijbehorende RAMING Digitaal wordt gebruik gemaakt van de indeling, 11 beroepsklassen en de onderliggende 127 beroepsgroepen. In RAMING Digitaal wordt bovendien een indeling naar 43 beroepssegmenten gebruikt (zie ook Bijlage B).

\section{Conjunctuurgevoeligheid}

De conjunctuurgevoeligheid van de werkgelegenheid heeft betrekking op de mate waarin de werkgelegenheid voor arbeidskrachten met een bepaalde opleidingsachtergrond of werkzaam in een bepaalde beroepsgroep gevoelig is voor veranderingen van de economische situatie. Deze indicator geeft daarmee de mate van werkzekerheid aan. De conjunctuurgevoeligheid wordt bepaald door de sectorale werkgelegenheidsfluctuaties in het verleden te relateren aan de mate waarin een opleidingstype of een beroepsgroep momenteel in de verschillende bedrijfssectoren is vertegenwoordigd. Hierbij wordt rekening gehouden met het feit dat niet ieder opleidingstype en elke beroepsgroep even sterk meefluctueren met de werkgelegenheidsschommelingen van de bedrijfssector.

\section{Deeltijdarbeid}

Deeltijdarbeid betreft personen die hoogstens 32 uur maar minstens 12 uur per week werkzaam zijn. 


\section{Eigen vakrichting}

Een indicatie van de mate waarin arbeidskrachten werkzaam zijn in een functie die niet goed aansluit bij de gevolge opleidingsrichting. De mate waarin schoolverlaters buiten de eigen vakrichting werkzaam zijn wordt in dit rapport vastgesteld door de schoolverlaters zelf te laten aangeven in hoeverre voor de door hen uitgeoefende functie de eigen of een verwante opleidingsrichting vereist is.

\section{Flexibel werk}

Van flexibel werk is sprake bij uitzendkrachten, oproepkrachten, invalkrachten, contracten zonder een vast aantal arbeidsuren en indien geen vast dienstverband is overeengekomen.

\section{Opleidingscategorie, Opleidingstype}

Alle voorkomende opleidingen zijn samengevoegd tot een aantal clusters. In de bij dit rapport verschenen RAMING Digitaal wordt voornamelijk uitgegaan van 28 opleidingscategorieën of 104 opleidingstypen. In het rapport wordt een indeling naar 17 opleidingscategorieën of een indeling naar de 104 onderliggende opleidingstypen gehanteerd (zie Bijlage B).

\section{Potentiële beroepsbevolking}

De potentiële beroepsbevolking omvat de werkenden, de werklozen en de nietparticiperenden. ledereen die in Gelderland woont en tussen de 15 en de 64 jaar oud is en geen voltijdopleiding volgt, wordt tot de potentiële beroepsbevolking van Gelderland gerekend. Als men meer dan 12 uur per week werkt, wordt men tot de werkzame beroepsbevolking gerekend. Werkt men niet of minder dan 12 uur, maar wil men wel minstens 12 uur per week betaalde arbeid verrichten, dan behoort men tot de werkloze beroepsbevolking. Werkt men niet of minder dan 12 uur, en is men niet op zoek naar betaalde arbeid voor minstens 12 uur per week, dan behoort men tot de niet-participerende beroepsbevolking (de zgn. 'stille reserve').

\section{Substitutiemogelijkheden}

Deze wordt bepaald met behulp van een spreidingsindex die te interpreteren is als het genormeerd aantal opleidingstypen waaruit werkenden in deze beroepsgroep afkomstig zijn. De spreidingsindex geeft de mate aan waarin werkgevers voor een bepaalde beroepsgroep arbeidskrachten kunnen aantrekken met een uiteenlopende opleidingsachtergrond, zodat ze niet afhankelijk zijn van het arbeidsaanbod van één bepaald opleidingstype.

\section{Toekomstig arbeidsmarktperspectief}

Het toekomstig arbeidsmarktperspectief geeft de verhouding tussen aanbod en vraag in de prognoseperiode voor een opleidingstype weer. Als het arbeidsmarktperspectief slecht is, betekent dit dat er in de komende jaren veel meer aanbod van nieuwkomers is dan er baanopeningen zijn. Hierdoor zal de arbeidsmarktpositie gaan verslechteren. Deze verslechtering kan een hogere werkloosheid betekenen, maar door aanpassingsprocessen op de arbeidsmarkt kan dit ook leiden tot het moeten aanvaarden van banen op een lager niveau, een lagere beloning en meer tijdelijke contracten. Omgekeerd zal een goed perspectief tot een grotere kans op werk, maar 
ook tot een verbeterde positie op andere punten leiden. Het toekomstig arbeidsmarktperspectief per opleidingstype wordt bepaald door middel van de Indicator Toekomstige Arbeidsmarktsituatie (ITA), die is gedefinieerd als de verhouding tussen enerzijds de verwachte instroom van schoolverlaters en het aantal kortdurig werklozen (i.e. korter dan 1 jaar werkloos) en anderzijds de verwachte baanopeningen. Naarmate de waarde van de indicator hoger is, is het perspectief slechter. Een waarde rond de 1 duidt op een evenwichtssituatie. Merk overigens op dat een hogere ITA een slechtere (toekomstige) arbeidsmarktsituatie impliceert, terwijl een hogere arbeidsmarktkrapte een indicatie is voor een betere (huidige) arbeidsmarktpositie van een opleidingstype.

\section{Toekomstige knelpunten in de Personeelsvoorziening}

Als de toekomstige vraag naar werkenden met een bepaalde opleidingsachtergrond groter is dan het aanbod, kunnen knelpunten in de personeelsvoorziening verwacht worden. Vergelijkbaar met de Indicator Toekomstige Arbeidsmarktsituatie (ITA, zie hierboven) geeft de Indicator Toekomstige Knelpunten in de Personeelsvoorziening (ITKP) deze vraag-aanbod-spanning aan. Het verschil met de ITA is dat bij de ITKP de uitstroom van werkenden als gevolg van een krimpende werkgelegenheid is meegerekend in de vraag, omdat verwacht mag worden dat bij knelpunten in de personeelsvoorziening deze (gedwongen) uitstroom kan worden afgeremd of elders werk zou kunnen vinden. Naarmate de waarde van de indicator lager is, zijn de verwachte knelpunten groter. Een waarde rond de 1 duidt op een evenwichtssituatie.

\section{Toekomstige Knelpunten in de personeelsvoorziening naar Beroep}

Om inzicht te verschaffen hoe de aansluitingsproblematiek tussen onderwijs en arbeidsmarkt zijn weerslag heeft op de wervingsproblematiek in de verschillende beroepsgroepen, wordt gebruik gemaakt van de Indicator Toekomstige Knelpunten in de Personeelsvoorziening naar Beroep (ITKB). De ITKB geeft aan in welke mate het voor werkgevers mogelijk is om de gewenste personeelssamenstelling naar opleidingsachtergrond binnen beroepen te realiseren bij de voorspelde vraagaanbod-verhoudingen voor de verschillende opleidingstypen. De ITKB heeft een waarde tussen 0 en 1 . Naarmate de waarde van de indicator lager is, zijn de knelpunten in de personeelsvoorziening voor de betreffende beroepsgroep groter. Werkgevers zullen dan relatief veel moeite hebben nieuw personeel met de door hen gewenste opleidingsachtergrond te vinden. Wanneer de ITKB daarentegen bijna gelijk is aan 1, zullen werkgevers weinig moeite hebben de gewenste personeelssamenstelling binnen het beroep te realiseren. Voor die opleidingen die aandacht schenken aan de in dat beroep relevante kennis en vaardigheden, worden dan geringe knelpunten verwacht.

\section{Uitbreidingsvraag}

De uitbreidingsvraag is de vraag naar nieuwe arbeidskrachten die ontstaat door groei van de werkgelegenheid. Als er sprake is van een werkgelegenheidsdaling, is de uitbreidingsvraag negatief. 


\section{Uitwijkmogelijkheden}

Dit is de mate waarin arbeidskrachten met een bepaalde opleidingsachtergrond terecht kunnen komen in andere beroepsgroepen op een aansluitend of hoger functieniveau. Deze maatstaf geeft daarmee aan in hoeverre arbeidskrachten afhankelijk zijn van de arbeidsmarktsituatie in een bepaald beroep. De uitwijkmogelijkheden worden bepaald met behulp van een spreidingsindex. Deze index geeft een indicatie van het aantal beroepsgroepen waarnaar men kan uitwijken.

\section{Vacature}

Openstaande vacatures die geregistreerd worden bij het $\mathrm{CWI}$, en vervolgens worden opgehoogd op basis van vacaturecijfers van het CBS. Het begrip vacature is in RAMING Digitaal gebaseerd op de door het CBS gehanteerde definitie van een openstaande vacature, zijnde een arbeidsplaats waarvoor personeel wordt gezocht dat onmiddellijk of zo spoedig mogelijk geplaatst kan worden.

\section{Vervangingsvraag}

Vervangingsvraag is de vraag naar nieuwe arbeidskrachten die ontstaat doordat de arbeidsplaatsen van werkenden die met pensioen gaan, arbeidsongeschikt worden of zich (tijdelijk) terugtrekken van de arbeidsmarkt, opnieuw moeten worden opgevuld. De vervangingsvraag per beroepsgroep kan bovendien ontstaan door de beroepsmobiliteit. Verder kan een onderscheid worden gemaakt tussen de netto en de bruto vervangingsvraag. De netto vervangingsvraag heeft alleen betrekking op de vervangingsbehoefte voor zover deze opgevuld zou moeten worden door schoolverlaters die op de arbeidsmarkt instromen. De bruto vervangingsvraag is de totale uitstroom van werkenden die vervangen moeten worden. De bruto vervangingsvraag omvat dus ook de vervangingsvraag die zou kunnen worden opgevuld door herintreders en baanwisselaars. In het huidige rapport wordt alleen de netto vervangingsvraag gebruikt en gepresenteerd.

\section{Werkende}

Het aantal werkenden heeft betrekking op iedereen die in Gelderland woont, ouder is dan 15 jaar, jonger is dan 65 jaar en minstens 12 uur per week werkt. Het betreft hier de werkenden die deel uit maken van de Gelderse beroepsbevolking. Deze kunnen derhalve ook buiten Gelderland werkzaam zijn. Ook het begrip 'werkgelegenheid' heeft betrekking op de werkzame beroepsbevolking van Gelderland.

\section{Werkloosheid}

Werkloosheid wordt gedefinieerd op basis van de CBS-definitie van de werkloze beroepsbevolking. Tot de werkloze beroepsbevolking worden gerekend de personen die niet of minder dan 12 uur werken en die:

- werk hebben aanvaard waardoor ze ten minste 12 uur per week gaan werken, of

- verklaren ten minste 12 uur per week te willen werken, daarvoor beschikbaar zijn en activiteiten ontplooien om werk voor ten minste 12 uur per week te vinden.

Het werkloosheidspercentage wordt normaal gesproken bepaald door het aantal werklozen te relateren aan de beroepsbevolking. In RAMING Digitaal is het aantal werklozen echter gedeeld door de potentiële bevolking (zie definitie in deze bijlage). 
Daarnaast hanteert het Etil in de regiorapportages een werkloosheidspercentage dat is gebaseerd op het aantal werkzoekenden van het CWI (zie definitie in deze bijlage en regiorapportages van het Etil).

\section{Werkzoekende}

Het begrip werkzoekende is in deze rapportage gedefinieerd als de het Centrum voor Werk en Inkomen (CWI) ingeschreven niet-werkende werkzoekenden, inclusief de categorie 'geen beroep op dienstverlening'. De werkzoekenden kunnen worden ingedeeld naar bemidddelingsfase (zie definitie in deze bijlage). 


\section{Bijlage B \\ Classificaties naar sector, beroep en opleiding ${ }^{44}$}

BEDRIJFSSECTOREN

Landbouw en visserij

Tuinbouw

Veehouderij

Akkerbouw, bosbouw en visserij

Voeding

Vlees- en visverwerking

Overige voedingsproducten

Drank en tabaksproducten

Chemie

Basischemie

Eindproducten chemie

Kunststofverwerking

Metaal en elektrotechniek

Basismetaal

Metaalproducten

Machine-industrie

Elektrotechniek

Transportmiddelen

Overige industrie

Textiel

Hout- en bouwmaterialen

Papier

Grafische industrie

Energie

Energie

Bouw en onroerend goed

Bouw

Exploitatie van onroerend goed

Handel en reparatie

Handel en reparatie

44. Zie Bijlage A voor meer uitleg over de indelingen. 
Transport en communicatie

Scheep- en luchtvaart

Weg- en railvervoer

Communicatie

Bank- en verzekeringswezen

Bankwezen

Verzekeringswezen

Horeca en zakelijke dienstverlening

Horeca

Zakelijke dienstverlening

Overige commerciële dienstverlening

Kwartaire diensten

Gezondheidszorg

Overige kwartaire diensten

Overheid en onderwijs

Onderwijs

Overheid 


\section{BEROEPEN}

\section{Beroepsklassen en onderliggende beroepsgroepen}

\section{Pedagogische beroepen}

Leraar basisonderwijs

Docenten exacte, medische en verzorgende vakken (2e graads)

Docenten exacte, medische en verzorgende vakken (1e graads en WO)

Docenten landbouw en techniek (2e graads)

Docenten landbouw en techniek (1e graads en WO)

Docenten economisch-administratieve vakken (2e graads)

Docenten economisch-administratieve vakken (1e graads en WO)

Docenten talen en expressie

Docenten letteren (1e graads en WO)

Docenten sociale vakken (2e graads)

Docenten sociale vakken (1e graads en WO)

Docenten 2 e graads zonder specialisatie

Docenten 1 e graads zonder specialisatie

Onderwijskundig medewerkers

Onderwijskundigen en pedagogen

Rij-instructeurs

Zweminstructeurs

Sportinstructeurs

Culturele beroepen

Tolken, vertalers en schrijvers

Bibliotheekassistenten

Bibliothecarissen

Grafisch ontwerpers

Kunstenaars

Geestelijk verzorgers

Geestelijken

Journalisten

Taalkundigen

Agrarische beroepen

Agrarische hulparbeiders

Agrarische arbeiders

Agrarische vakkrachten

Milieuhygiënisten en agrarisch vertegenwoordigers

Landbouwkundigen

Landbouwmachinebestuurders en vissers

Agrarische bedrijfshoofden

Technische, ambachts- en industrieberoepen

Productiemedewerkers

Laboratorium-assistenten 
Laboranten

Technisch analisten

Natuurwetenschappers

Conciërges

Hoofden technische dienst

Werktuigbouwkundigen

Bouwvakkers

Aannemers en installateurs

Architecten en bouwkundig projectleiders

Weg-en waterbouwkundigen

Weg- en waterbouwkundige arbeiders

Weg- en waterbouwkundige vakkrachten

Weg- en waterbouwkundig ontwerpers en projectleiders

Metaalarbeiders

Bankwerkers en lassers

Bedrijfshoofden metaalbewerking

Assembleurs

Monteurs

Werktuigbouwkundig ontwerpers en hoofden technische dienst

Elektronicamonteurs

Monteurs en controleurs elektrotechnische producten

Elektromonteurs

Elektrotechnisch ontwerpers en bedrijfshoofden

Elektrotechnici

Grafisch productiepersoneel

Grafische vakkrachten

Mechanisch operators

Procesoperators

Procestechnologen

Materiaalkundigen

Confectie-arbeiders

Schoen- en kleermakers

\section{Transportberoepen}

Laders en lossers

Chauffeurs

Schippers en conducteurs

Vliegers, scheepskapiteins en leidinggevenden transport

Stewards

Medische en paramedische beroepen

Verpleeghulpen en leerling-verpleegkundigen

Verplegenden en doktersassistenten

Therapeuten en verpleegkundigen

Artsen

Apothekersassistenten en medisch laboranten Medisch analisten 
Apothekers

Afdelingshoofden zorginstelling

Economisch-administratieve beroepen

Kantoorhulpen, inpakkers en colporteurs

Ondersteunende administratieve hulpkrachten

Bedrijfshoofden

Economen

Productieplanners

Organisatie-adviseurs

Organisatiedeskundigen

Receptionisten en administratieve employés

Boekhouders en secretaresses

Assistent accountants

Accountants

Verzekeringsagenten

Commercieel employés

Commercieel medewerkers

Technisch-commercieel employés

Technisch-bedrijfskundig medewerkers

Juridisch en fiscaal medewerkers

Juridisch, bestuurlijk medewerkers

Juristen

Administratieve transportemployés

Leidinggevenden

Managers

Medisch secretaresses

Informatica beroepen

Programmeurs

Systeemanalisten

Informatici

Technisch systeemanalisten

Sociaal-culturele beroepen

Activiteitenbegeleiders en medewerkers arbeidsbemiddeling Medewerkers sociaal-cultureel werk en personeel en arbeid Hoofden sociaal-cultureel werk en personeel en arbeid

Sociaal-wetenschappelijk medewerkers

Sociaal-wetenschappelijk onderzoekers

Verzorgende en dienstverlenende beroepen

Vakkenvullers

Interieurverzorgers

Verkopers

Winkeliers

Hulpkrachten horeca en verzorging 
Ziekenverzorgenden

Verzorgend personeel

Café- en snackbarhouders

Bedrijfshoofden horeca

Bakkers en slagers

Openbare orde- en veiligheidsberoepen

Aspirant politieagenten, soldaten en beveiligingshulpkrachten

Politieagenten, onderofficieren en beveiligingsemployés

Politie-inspecteurs en officieren

Brandweerlieden

\section{Beroepssegmenten en onderliggende beroepsgroepen}

\section{Elementaire beroepen}

Kantoorhulpen, inpakkers en colporteurs

Agrarische hulparbeiders

Productiemedewerkers

Laders en lossers

Vakkenvullers

Interieurverzorgers

Lagere niet-specialistische beroepen

Ondersteunende administratieve hulpkrachten

Lagere docenten sportvakken

Zweminstructeurs

Lagere agrarische beroepen

Agrarische arbeiders

Landbouwmachinebestuurders en vissers

Lagere wiskundige, natuurwetenschappelijke beroepen

Laboratorium-assistenten

Lagere technische beroepen

Conciërges

Bouwvakkers

Weg- en waterbouwkundige arbeiders

Metaalarbeiders

Assembleurs

Monteurs en controleurs elektrotechnische producten

Grafisch productiepersoneel

Mechanisch operators

Confectie-arbeiders 
Lagere transportberoepen

Chauffeurs

Lagere (para)medische beroepen

Verpleeghulpen en leerling-verpleegkundigen

Lagere administratieve, commerciële beroepen e.d.

Receptionisten en administratieve employés

Verzekeringsagenten

Verkopers

Lagere beveiligingsberoepen

Aspirant politieagenten, soldaten en beveiligingshulpkrachten

Lagere verzorgende beroepen

Hulpkrachten horeca en verzorging

Café- en snackbarhouders

Middelbare docenten transport-, sportvakken

Rij-instructeurs

Sportinstructeurs

Middelbare agrarische beroepen

Agrarische vakkrachten

Agrarische bedrijfshoofden

Middelbare wiskundige, natuurwetenschappelijke beroepen

Laboranten

Middelbare technische beroepen

Hoofden technische dienst

Aannemers en installateurs

Weg- en waterbouwkundige vakkrachten

Bankwerkers en lassers

Monteurs

Elektronicamonteurs

Elektromonteurs

Grafische vakkrachten

Procesoperators

Bakkers en slagers

Schoen- en kleermakers

Brandweerlieden 
Middelbare transportberoepen e.d.

Schippers en conducteurs

Administratieve transportemployés

Stewards

Middelbare (para)medische beroepen

Verplegenden en doktersassistenten

Apothekersassistenten en medisch laboranten

Medisch secretaresses

Ziekenverzorgenden

Middelbare administratieve, commerciële beroepen e.d.

Productieplanners

Programmeurs

Boekhouders en secretaresses

Commercieel employés

Winkeliers

Technisch-commercieel employés

Middelbare juridische, bestuurlijke beveiligingsberoepen Juridisch en fiscaal medewerkers

Politieagenten, onderofficieren en beveiligingsemployés

Middelbare taalkundige, culturele beroepen

Bibliotheekassistenten

Grafisch ontwerpers

Middelbare beroepen $m, b, t$, gedrag en maatschappij

Activiteitenbegeleiders en medewerkers arbeidsbemiddeling

Middelbare verzorgende beroepen ed,

Verzorgend personeel

Bedrijfshoofden horeca

Hogere pedagogische beroepen

Docenten $2^{\mathrm{e}}$ en $3^{\mathrm{e}}$ graads zonder specialisatie

Onderwijskundig medewerkers

Leraar basisonderwijs

Docenten exacte, medische en verzorgende vakken $\left(2^{\mathrm{e}}\right.$ en $3^{\mathrm{e}} \mathrm{gr}$.)

Docenten landbouw en techniek $\left(2^{\mathrm{e}}\right.$ en $3^{\mathrm{e}} \mathrm{gr}$.)

Docenten economisch-administratieve vakken $\left(2^{\mathrm{e}}\right.$ en $3^{\mathrm{e}} \mathrm{gr}$. $)$

Docenten talen en expressie

Docenten sociale vakken $\left(2^{\mathrm{e}}\right.$ en $3^{\mathrm{e}} \mathrm{gr}$.)

Hogere landbouwkundige beroepen

Milieuhygiënisten en agrarisch vertegenwoordigers 
Hogere wiskundige, natuurwetenschappelijke beroepen

Technisch analisten

Hogere technische beroepen

Architecten en bouwkundig projectleiders

Weg- en waterbouwkundig ontwerpers en projectleiders

Bedrijfshoofden metaalbewerking

Werktuigbouwkundig ontwerpers en hoofden technische dienst

Technisch systeemanalisten

Elektrotechnisch ontwerpers en bedrijfshoofden

Procestechnologen

Hogere transportberoepen

Vliegers, scheepskapiteins en leidinggevenden transport

Hogere (para)medische beroepen

Therapeuten en verpleegkundigen

Medisch analisten

Hogere administratieve, commerciële, economische beroepen

Bedrijfshoofden

Organisatie-adviseurs

Systeemanalisten

Assistent accountants

Commercieel medewerkers

Technisch-bedrijfskundig medewerkers

Hogere juridische, bestuurlijke, beveiligingsberoepen Juridisch, bestuurlijk medewerkers

Politie-inspecteurs en officieren

Hogere taalkundige, culturele beroepen

Tolken, vertalers en schrijvers

Bibliothecarissen

Kunstenaars

Hogere beroepen m.b.t. gedrag en maatschappij e.d.

Geestelijk verzorgers

Sociaal-cultureel werkers

Journalisten

Sociaal-wetenschappelijk medewerkers

Hogere verzorgende beroepen

Afdelingshoofden zorginstelling 
Managers (hbo werk- en denkniveau) e.d.

Leidinggevenden

Wetenschappelijke pedagogische beroepen

Docent $1^{\mathrm{e}}$ graads zonder specialisatie

Onderwijskundigen en pedagogen

Docenten exacte, medische en verzorgende vakken $\left(1^{\mathrm{e}} \mathrm{gr}\right.$. en wo)

Docenten landbouw en techniek $\left(1^{\mathrm{e}} \mathrm{gr}\right.$. en wo

Docenten economisch-administratieve vakken $\left(1^{\mathrm{e}} \mathrm{gr}\right.$. en wo)

Docenten letteren $\left(1^{\mathrm{e}} \mathrm{gr}\right.$. en wo)

Docenten sociale vakken $\left(1^{\mathrm{e}} \mathrm{gr}\right.$. en wo)

Wetenschappelijke landbouwkundige beroepen

Landbouwkundigen

Wetenschappelijke wiskundige, natuurwetenschappelijke beroepen

Natuurwetenschappers

Wetenschappelijke technische beroepen

Werktuigbouwkundigen

(weg- en water)bouwkundigen

Elektrotechnici

Materiaalkundigen

Wetenschappelijke (para)medische beroepen e.d.

Artsen

Apothekers

Wetenschappelijke economische, administratieve beroepen ed,

Economen

Orgnisatiedeskundigen

Informatici

Accountants

Wetenschappelijke juridische, bestuurlijke beroepen Juristen

Wetenschappelijke beroepen m.b.t. gedrag en maatschappij

Geestelijken

Sociale raadslieden en hoofden personeelszaken

Taalkundigen

Sociaal-wetenschappelijk onderzoekers

Managers (wetenschappelijk werk- en denkniveau)

Managers

80 


\section{OPLEIDINGEN}

\section{Opleidingscategorieën en onderliggende opleidingstypen}

Basisonderwijs

Basisonderwijs

VMBO Theorie

VMBO theorie

VMBO Natuur en techniek

VMBO landbouw en natuurlijke omgeving

VMBO bouwtechniek

VMBO installatietechniek

VMBO mechanische techniek

VMBO fijnmechanische techniek

VMBO voertuigentechniek

VMBO elektrotechniek

VMBO grafische techniek

VMBO brood en banket

VMBO transport en logistiek

VMBO Economie

VMBO administratie, handel en mode

VMBO consumptief en levensmiddelentechniek

VMBO beveiliging

VMBO Verzorging

VMBO (uiterlijke) verzorging

\section{HAVONWO}

HAVO/VWO

MBO Natuur en techniek

MBO voeding, natuur en milieu

$\mathrm{MBO}$ groene ruimte

MBO laboratorium

MBO bouw

MBO grond-, weg- en waterbouw

MBO installatietechniek

MBO werktuigbouw en mechanische techniek

MBO fijnmechanische techniek

MBO motorvoertuigentechniek en tweewielers

MBO vliegtuigtechniek

MBO operationele techniek

MBO elektrotechniek

MBO grafische techniek 
MBO procestechniek

MBO brood en banket

MBO levensmiddelentechniek/vleesverwerking

MBO vervoer

MBO Economie

$\mathrm{MBO}$ administratie en logistiek

MBO handel

MBO secretariaat

MBO toerisme en recreatie

$\mathrm{MBO}$ facilitaire dienstverlening

MBO ICT

$\mathrm{MBO}$ geld, bank en belastingen

MBO verzekeringswezen

MBO openbare orde en veiligheid

MBO Dienstverlening en gezondheidszorg

MBO dokters-, tandarts- en dierenartsassistent

MBO apothekersassistent

$\mathrm{MBO}$ verpleging

MBO gezondheidstechniek

MBO sociaal-pedagogisch en welzijn

MBO verzorging

MBO uiterlijke verzorging

MBO horeca

MBO beweging en therapie

HBO Natuur en techniek

$\mathrm{HBO}$ landbouw en veeteelt

$\mathrm{HBO}$ milieukunde en levensmiddelentechnologie

HBO laboratorium

HBO bouwkunde

HBO civiele techniek

HBO werktuigbouwkunde

HBO elektrotechniek

HBO informatica

HBO chemische technologie

$\mathrm{HBO}$ vervoer en logistiek

HBO Economie

HBO accountancy en bedrijfseconomie

HBO commerciële economie

$\mathrm{HBO}$ toerisme en recreatie

HBO recht en bestuur

HBO secretariaat

HBO bedrijfskunde

$\mathrm{HBO}$ openbare orde en veiligheid 
HBO Onderwijs en sociaal-cultureel

HBO lerarenopleiding basisonderwijs

HBO lerarenopleiding talen

HBO lerarenopleiding natuur en techniek

HBO lerarenopleiding economie en maatschappij

HBO lerarenopleiding lichamelijke opvoeding

$\mathrm{HBO}$ lerarenopleiding medisch en verzorging

HBO lerarenopleiding expressie

$\mathrm{HBO}$ tolk en vertaler

HBO communicatie en journalistiek

HBO maatschappelijk werk en hulpverlening

$\mathrm{HBO}$ personeel en arbeid

$\mathrm{HBO}$ bibliotheek en documentatie

$\mathrm{HBO}$ uitvoerende en beeldende kunsten

HBO Paramedisch

$\mathrm{HBO}$ verpleegkunde

HBO (fysio)therapie

$\mathrm{HBO}$ voeding

$\mathrm{HBO}$ radiologie

WO Natuur en techniek

WO landbouw en milieukunde

WO wiskunde en natuurwetenschappen

WO bouwkunde

WO civiele techniek

WO werktuigbouwkunde

WO elektrotechniek

WO informatica en bestuurlijke informatiekunde

WO Economie

WO econom(etr)ie

WO bedrijfskunde

WO accountancy en belastingen

WO rechten en bestuurskunde

WO Letteren en sociaal-cultureel

WO letteren

WO theologie

WO sociale wetenschappen

WO kunstwetenschappen

WO Medisch

WO (dier)geneeskunde

WO tandheelkunde

WO farmacie en medische biologie 



\section{Bijlage C \\ RAMING Digitaal}

\section{RAMING Digitaal}

RAMING Digitaal is een arbeidsmarktinformatiesysteem waarmee $\mathrm{u}$ zelf tabellen kunt samenstellen.

Hierbij dient u te beschikken over Microsoft Access.

De tabellen kunnen eenvoudig worden geëxporteerd naar Microsoft Excel ter verdere bewerking en aanvulling.

\section{Aard van informatie}

Het arbeidsmarktinformatiesysteem bestaat uit drie delen, die betrekking hebben op de arbeidsmarktinformatie naar:

$$
\begin{array}{ll}
\text { - } & \text { Bedrijven; } \\
\text { - } & \text { Beroepen; } \\
\text { - } & \text { Opleidingen. }
\end{array}
$$

Met behulp van RAMING Digitaal kan een systematisch kwantitatief overzicht worden verkregen van de arbeidsmarktgegevens en de verwachte ontwikkelingen die ten grondslag liggen aan de beschrijving op hoofdlijnen in het voorliggende rapport.

De actuele arbeidsmarktinformatie en de prognoses over werkenden en schoolverlaters worden in RAMING Digitaal veel verder uitgesplitst dan in dit rapport.

Daarnaast bevat het systeem gegevens over de werkzame en niet-werkzame bevolking, over werkzoekenden en vacatures, en over de deelname en uitstroom in het voortgezet en middelbaar onderwijs.

\section{Downloaden}

RAMING Digitaal is, evenals het voorliggende hoofdrapport, te downloaden op de website van de provincie Gelderland: www.gelderland.nl, via de buttons 'Ondernemen' en 'Arbeidsmarkt'.

\section{Software}

De vereiste software voor Raming Digitaal is Microsoft Acces (minimaal versie 2000, 2003 of XP).

\section{Informatie}

Voor meer informatie over het gebruik van RAMING Digitaal kunt u contact opnemen met dhr. S. Dijksman van het ROA (S.Dijksman@roa.unimaas.nl).

Voor inhoudelijke vragen over deze rapportage of RAMING Digitaal kunt u contact opnemen met dhr. M. Walsweer van Bureau Economisch Onderzoek van de provincie Gelderland (zie www.gelderland.nl), of met dhr. F. Cörvers van het ROA (zie www.roa.unimaas.nl). 